Cochrane Database of Systematic Reviews

\title{
Therapeutic ultrasound for venous leg ulcers (Review)
}

Cullum N, Liu Z

Cullum N, Liu Z.

Therapeutic ultrasound for venous leg ulcers.

Cochrane Database of Systematic Reviews 2017, Issue 5. Art. No.: CD001180.

DOI: 10.1002/14651858.CD001180.pub4.

www.cochranelibrary.com 
TABLE OF CONTENTS

ABSTRACT

PLAIN LANGUAGE SUMMARY

SUMMARY OF FINDINGS

BACKGROUND

OBJECTIVES

METHODS

Figure 1.

Figure 2.

RESULTS

Figure 3.

DISCUSSION

AUTHORS' CONCLUSIONS

ACKNOWLEDGEMENTS

REFERENCES

CHARACTERISTICS OF STUDIES

DATA AND ANALYSES

Analysis 1.1. Comparison 1 High frequency US vs no US, Outcome 1 Proportion of ulcers completely healed at 3 weeks. ........

Analysis 1.2. Comparison 1 High frequency US vs no US, Outcome 2 Proportion of ulcers completely healed at 7 or 8 weeks. ...

Analysis 1.3. Comparison 1 High frequency US vs no US, Outcome 3 Proportion of ulcers completely healed at 12 weeks. ......

Analysis 1.4. Comparison 1 High frequency US vs no US, Outcome 4 Proportion of ulcers completely healed at 12 months (nursereported data).

Analysis 1.5. Comparison 1 High frequency US vs no US, Outcome 5 HRQoL: 12-week SF-12 Physical Component Score. .........

Analysis 1.6. Comparison 1 High frequency US vs no US, Outcome 6 HRQoL: 12 -week SF-12 Mental Component Score. ............

Analysis 1.7. Comparison 1 High frequency US vs no US, Outcome 7 HRQoL: 12-month SF-12 Physical Component Score. ......

Analysis 1.8. Comparison 1 High frequency US vs no US, Outcome 8 HRQoL: 12-month SF-12 Mental Component Score. ........

Analysis 1.9. Comparison 1 High frequency US vs no US, Outcome 9 Non-serious and serious adverse events.

Analysis 2.1. Comparison 2 Low frequency US vs no US, Outcome 1 Proportion of ulcers completely healed at 8-12 weeks. .... ADDITIONAL TABLES

APPENDICES

WHAT'S NEW

HISTORY

CONTRIBUTIONS OF AUTHORS

DECLARATIONS OF INTEREST

SOURCES OF SUPPORT

DIFFERENCES BETWEEN PROTOCOL AND REVIEW

INDEX TERMS 
[Intervention Review]

\section{Therapeutic ultrasound for venous leg ulcers}

Nicky Cullum ${ }^{1,2}$, Zhenmi Liu1

1Division of Nursing, Midwifery \& Social Work, School of Health Sciences, Faculty of Biology, Medicine \& Health, University of Manchester, Manchester Academic Health Science Centre, Manchester, UK. ${ }^{2}$ Research and Innovation Division, Central Manchester University Hospitals NHS Foundation Trust, Manchester Academic Health Science Centre, Manchester, UK

Contact: Nicky Cullum, Division of Nursing, Midwifery \& Social Work, School of Health Sciences, Faculty of Biology, Medicine \& Health, University of Manchester, Manchester Academic Health Science Centre, Jean McFarlane Building, Oxford Road, Manchester, M13 9PL, UK. nicky.cullum@manchester.ac.uk.

Editorial group: Cochrane Wounds Group.

Publication status and date: New search for studies and content updated (no change to conclusions), published in Issue 5, 2017.

Citation: Cullum N, Liu Z. Therapeutic ultrasound for venous leg ulcers. Cochrane Database of Systematic Reviews 2017, Issue 5. Art. No.: CD001180. DOI: 10.1002/14651858.CD001180.pub4.

Copyright () 2017 The Cochrane Collaboration. Published by John Wiley \& Sons, Ltd.

\section{A B S T R A C T}

\section{Background}

Venous leg ulcers are a type of chronic, recurring, complex wound that is more common in people aged over 65 years. Venous ulcers pose a significant burden to patients and healthcare systems. While compression therapy (such as bandages or stockings) is an effective firstline treatment, ultrasound may have a role to play in healing venous ulcers.

\section{Objectives}

To determine whether venous leg ulcers treated with ultrasound heal more quickly than those not treated with ultrasound.

\section{Search methods}

We searched the Cochrane Wounds Specialised Register (searched 19 September 2016); the Cochrane Central Register of Controlled Trials (CENTRAL; the Cochrane Library 2016, Issue 8); Ovid MEDLINE (including In-Process \& Other Non-Indexed Citations, MEDLINE Daily and Epub Ahead of Print) (1946 to 19 September 2016); Ovid Embase (1974 to 19 September 2016); and EBSCO CINAHL Plus (1937 to 19 September 2016). We also searched three clinical trials registries and the references of included studies and relevant systematic reviews. There were no restrictions based on language, date of publication or study setting.

\section{Selection criteria}

Randomised controlled trials (RCTs) that compared ultrasound with no ultrasound. Eligible non-ultrasound comparator treatments included usual care, sham ultrasound and alternative leg ulcer treatments.

\section{Data collection and analysis}

Two authors independently assessed the search results and selected eligible studies. Details from included studies were summarised using a data extraction sheet, and double-checked. We attempted to contact trial authors for missing data.

\section{Main results}

Eleven trials are included in this update; 10 of these we judged to be at an unclear or high risk of bias. The trials were clinically heterogeneous with differences in duration of follow-up, and ultrasound regimens. Nine trials evaluated high frequency ultrasound; seven studies provided data for ulcers healed and two provided data on change in ulcer size only. Two trials evaluated low frequency ultrasound and both reported ulcers healed data. 
It is uncertain whether high frequency ultrasound affects the proportion of ulcers healed compared with no ultrasound at any of the time points evaluated: at seven to eight weeks (RR 1.21, 95\% Cl 0.86 to 1.71; 6 trials, 678 participants; low quality evidence - downgraded once for risk of bias and once for imprecision); at 12 weeks (RR 1.26, 95\% Cl 0.92 to $1.73 ; 3$ trials, 489 participants; moderate quality evidence - downgraded once for imprecision); and at 12 months (RR 0.93, 95\% Cl 0.73 to 1.18; 1 trial, 337 participants; low quality evidence - downgraded once for unclear risk of bias and once for imprecision).

One trial (92 participants) reported that a greater percentage reduction in ulcer area was achieved at four weeks with high-frequency ultrasound, while another (73 participants) reported no clear difference in change in ulcer size at seven weeks. We downgraded the level of this evidence to very low, mainly for risk of bias (typically lack of blinded outcome assessment and attrition) and imprecision.

Data from one trial (337 participants) suggest that high frequency ultrasound may increase the risk of non-serious adverse events (RR 1.29, $95 \% \mathrm{Cl} 1.02$ to 1.64 ; moderate quality evidence - downgraded once for imprecision) and serious adverse events ( $R R$ 1.89; moderate quality evidence downgraded once for imprecision).

It is uncertain whether low frequency ultrasound affects venous ulcer healing at eight and 12 weeks (RR $3.91,95 \% \mathrm{Cl} 0.47$ to $32.85 ; 2$ trials, 61 participants; very low quality evidence (downgraded for risk of bias and imprecision)).

High-frequency ultrasound probably makes little or no difference to quality of life (moderate quality evidence, downgraded for imprecision). The outcomes of adverse effects, quality of life and cost were not reported for low-frequency ultrasound treatment.

\section{Authors' conclusions}

It is uncertain whether therapeutic ultrasound (either high or low frequency) improves the healing of venous leg ulcers. We rated most of the evidence as low or very low quality due to risk of bias and imprecision.

\section{PLAIN LANGUAGE SUMMARY}

\section{Can ultrasound therapy help to heal venous (varicose) leg ulcers and/or improve symptoms?}

\section{What are venous leg ulcers, and who is at risk?}

Venous leg ulcers are common wounds caused by damage or blockages in leg veins. This leads to pooling of blood and increased pressure in these veins. Eventually these changes can damage the skin and underlying tissue and form a long-lasting wound, or ulcer. These ulcers can be painful and leak fluid. They can also become infected. People at risk of developing venous leg ulcers include the elderly and those with mobility problems. They can be distressing for patients and costly to healthcare systems.

\section{Why use ultrasound to treat leg ulcers?}

Treatments for venous leg ulcers include compression bandages, which improve blood-flow in the legs, wound dressings, and medication such as antibiotics. Ultrasound therapy is sometimes used as an additional intervention, especially for difficult, long-standing ulcers. Sound waves are passed through the skin causing the tissue underneath to vibrate. The mechanisms by which ultrasound waves interact with healing tissues are not fully understood; they may have a positive or negative impact on the blood flow around the ulcers. We wanted to discover whether using ultrasound therapy can improve the healing of leg ulcers.

\section{What we found?}

In September 2016 we searched for randomised controlled trials (RCTs) that investigated whether ultrasound helps to heal or improves the symptoms of venous leg ulcers. We found 11 trials involving a total of 969 participants. The average (mean) age of participants ranged from 59 years to 70 years. The proportion of female participants ranged from $55 \%$ to $79 \%$. Eight studies compared ultrasound with use of no ultrasound for venous leg ulcers and the other three compared ultrasound with sham ultrasound. Seven out of the eleven studies were at high risk of bias and we could not assess the potential bias in three studies due to poor reporting. One study was at low risk of bias. The trials were all different, for example in their duration of follow-up (three weeks to 12 months), and the strength of the ultrasound waves used (high or low frequency ultrasound). It is not clear from this evidence whether ultrasound (high or low frequency) increases the healing of venous leg ulcers. The results of one study (337 participants) suggest that high-frequency ultrasound may be associated with more adverse events such as pain and skin redness (moderate quality evidence). The two studies that evaluated low-frequency ultrasound did not report whether participants experienced side effects. It is also uncertain whether either high-or low-frequency ultrasound affects participants' quality of life.

\section{Quality of the evidence}

Most of the studies we found did not have many participants, had short follow-up times and had weaknesses of study design that meant they were quite likely to give a misleading result. We consider the available evidence to be low quality due to these risks of bias.

This plain language summary is up to date as of September 2016. 
SUMMARY OF FINDINGS

\section{Summary of findings for the main comparison. High frequency ultrasound compared with no ultrasound for people with venous leg ulcers}

High frequency ultrasound compared with no ultrasound for people with venous leg ulcers

Patient or population: people with venous leg ulcers

Setting: any

Intervention: high frequency ultrasound

Comparison: no ultrasound

\begin{tabular}{|c|c|c|c|c|c|c|}
\hline \multirow[t]{2}{*}{ Outcomes } & \multicolumn{2}{|c|}{ Anticipated absolute effects ${ }^{\star}(95 \% \mathrm{CI})$} & \multirow{2}{*}{$\begin{array}{l}\text { Relative effect } \\
(95 \% \mathrm{Cl})\end{array}$} & \multirow{2}{*}{$\begin{array}{l}\text { № of partici- } \\
\text { pants } \\
\text { (studies) }\end{array}$} & \multirow{2}{*}{$\begin{array}{l}\text { Quality of the } \\
\text { evidence } \\
\text { (GRADE) }\end{array}$} & \multirow[t]{2}{*}{ Comments } \\
\hline & $\begin{array}{l}\text { Risk with no ultra- } \\
\text { sound }\end{array}$ & $\begin{array}{l}\text { Risk with high frequency ultra- } \\
\text { sound }\end{array}$ & & & & \\
\hline \multirow{4}{*}{$\begin{array}{l}\text { Proportion of ulcers } \\
\text { completely healed at } 3 \\
\text { weeks }\end{array}$} & Study population & & \multirow{4}{*}{$\begin{array}{l}\text { RR } 2.05 \\
\text { (0.24 to } 17.23)\end{array}$} & \multirow{4}{*}{$\begin{array}{l}65 \\
(1 \mathrm{RCT})\end{array}$} & \multirow{4}{*}{$\begin{array}{l}\oplus \odot \odot \ominus \\
\text { VERY LOW } \\
1,2,3,4\end{array}$} & \multirow{4}{*}{$\begin{array}{l}\text { Highly uncertain whether } \\
\text { high frequency ultrasound } \\
\text { affects healing at } 3 \text { weeks. }\end{array}$} \\
\hline & 45 per 1000 & $\begin{array}{l}93 \text { per } 1000 \\
\text { (11 to } 783)\end{array}$ & & & & \\
\hline & \multicolumn{2}{|l|}{ Moderate } & & & & \\
\hline & 45 per 1000 & $\begin{array}{l}92 \text { per } 1000 \\
\text { (11 to } 775)\end{array}$ & & & & \\
\hline \multirow{4}{*}{$\begin{array}{l}\text { Proportion of ulcers } \\
\text { completely healed at } \\
7 \text { or } 8 \text { weeks: losses to } \\
\text { follow-up regarded as } \\
\text { unhealed }\end{array}$} & \multicolumn{2}{|l|}{ Study population } & \multirow{4}{*}{$\begin{array}{l}\text { RR } 1.21 \\
\text { (0.86 to } 1.71)\end{array}$} & \multirow{4}{*}{$\begin{array}{l}678 \\
(6 \mathrm{RCTs})\end{array}$} & \multirow{4}{*}{$\begin{array}{l}\oplus \oplus \ominus \ominus \\
\text { LOW } 5,6\end{array}$} & \multirow{4}{*}{$\begin{array}{l}\text { Highly uncertain whether } \\
\text { high frequency ultrasound } \\
\text { affects healing at } 7 \text { to } 8 \\
\text { weeks. }\end{array}$} \\
\hline & 166 per 1000 & $\begin{array}{l}198 \text { per } 1000 \\
\text { (143 to } 284)\end{array}$ & & & & \\
\hline & \multicolumn{2}{|l|}{ Moderate } & & & & \\
\hline & 218 per 1000 & $\begin{array}{l}259 \text { per } 1000 \\
\text { (187 to } 372)\end{array}$ & & & & \\
\hline \multirow{4}{*}{$\begin{array}{l}\text { Proportion of ulcers } \\
\text { completely healed at } \\
12 \text { weeks: losses to fol- } \\
\text { low-up regarded as } \\
\text { unhealed }\end{array}$} & \multicolumn{2}{|l|}{ Study population } & \multirow{4}{*}{$\begin{array}{l}\text { RR } 1.26 \\
\text { (0.92 to } 1.73)\end{array}$} & \multirow{4}{*}{$\begin{array}{l}489 \\
\text { (3 RCTs) }\end{array}$} & \multirow{4}{*}{$\begin{array}{l}\oplus \oplus \oplus \odot \\
\text { MODERATE } 7\end{array}$} & \multirow{4}{*}{$\begin{array}{l}\text { Uncertain whether high } \\
\text { frequency ultrasound af- } \\
\text { fects healing at } 12 \text { weeks. }\end{array}$} \\
\hline & 202 per 1000 & $\begin{array}{l}255 \text { per } 1000 \\
(186 \text { to } 350)\end{array}$ & & & & \\
\hline & \multicolumn{2}{|l|}{ Moderate } & & & & \\
\hline & 304 per 1000 & 383 per 1000 & & & & \\
\hline
\end{tabular}




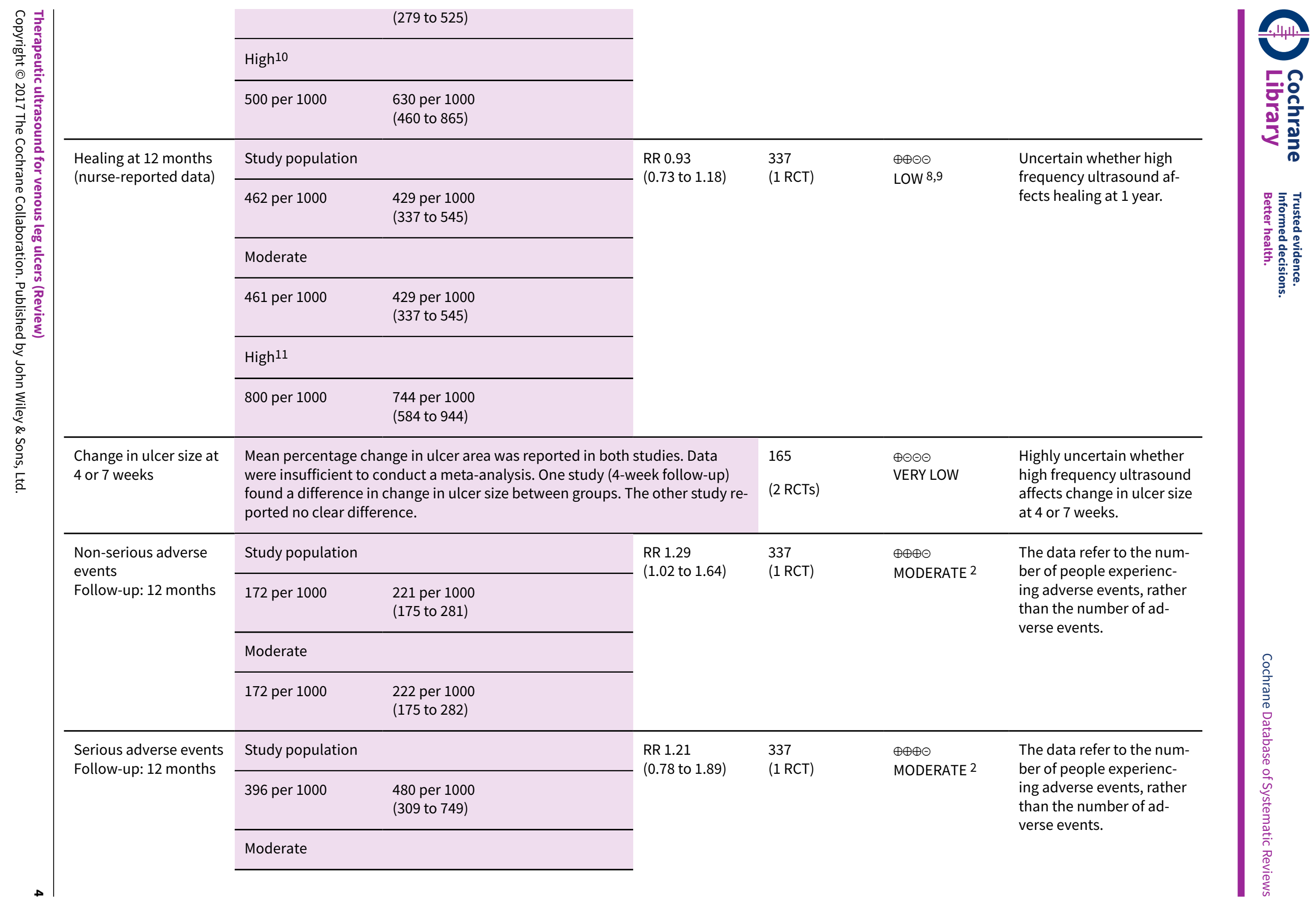




\begin{tabular}{|c|c|c|c|c|c|c|}
\hline & 396 per 1000 & $\begin{array}{l}479 \text { per } 1000 \\
\text { (309 to } 748)\end{array}$ & & & & \\
\hline $\begin{array}{l}\text { HRQoL: } 12 \text {-week SF-12 } \\
\text { mean Physical/Mental } \\
\text { Component Scores } \\
\text { scale from } 0 \text { to } 100 \\
\text { Follow-up: } 12 \text { weeks }\end{array}$ & $\begin{array}{l}\text { Physical Compo- } \\
\text { nent Score (PCS) } \\
\text { mean (SD): } 34.96 \\
(11.39) \\
\text { Mental Component } \\
\text { Score (MCS) mean } \\
\text { (SD): } 46.83(11.38)\end{array}$ & $\begin{array}{l}\text { PCS in the ultrasound group was } \\
1.09 \text { lower ( } 3.75 \text { lower to } 1.57 \text { high- } \\
\text { er) } \\
\text { MCS in the ultrasound group was } \\
0.88 \text { lower ( } 3.62 \text { lower to } 1.86 \text { high- } \\
\text { er) }\end{array}$ & See comment & $\begin{array}{l}285 \\
(1 \mathrm{RCT})\end{array}$ & $\begin{array}{l}\oplus \oplus \oplus \ominus \\
\text { MODERATE } 2\end{array}$ & $\begin{array}{l}\text { No clear differences in } \\
\text { physical or mental HRQoL } \\
\text { at } 12 \text { weeks }\end{array}$ \\
\hline $\begin{array}{l}\text { HRQoL: } 12 \text {-month } \\
\text { SF-12 Physical Compo- } \\
\text { nent Score } \\
\text { Scale from: } 0 \text { to } 100 \\
\text { Follow-up: } 12 \text { months }\end{array}$ & $\begin{array}{l}\text { PCS mean (SD): } \\
35.57 \text { (1.88) } \\
\text { MCS mean (SD): } \\
45.41(12.15)\end{array}$ & $\begin{array}{l}\text { PCS in ultrasound group was } 0.96 \\
\text { lower ( } 3.17 \text { lower to } 1.25 \text { higher) } \\
\text { MCS in ultrasound group was } 2.1 \\
\text { higher ( } 0.97 \text { lower to } 5.17 \text { higher) }\end{array}$ & See comment & $\begin{array}{l}229 \\
(1 \mathrm{RCT})\end{array}$ & $\begin{array}{l}\oplus \oplus \oplus \ominus \\
\text { MODERATE } 2\end{array}$ & $\begin{array}{l}\text { No clear differences in } \\
\text { physical or mental HRQoL } \\
\text { at } 12 \text { months }\end{array}$ \\
\hline $\begin{array}{l}\text { Cost } \\
\text { Follow-up: } 12 \text { months }\end{array}$ & $\begin{array}{l}\text { Addition of ultrasour } \\
\text { participant per year }\end{array}$ & $\begin{array}{l}\text { d treatment to standard care cost GBP } \\
95 \% \text { bias-corrected CI GBP }-35.19 \text { to } \mathrm{G}\end{array}$ & $\begin{array}{l}\text { 197.88 more per } \\
\text { P 420.32) }\end{array}$ & $\begin{array}{l}337 \\
(1 \mathrm{RCT})\end{array}$ & $\begin{array}{l}\oplus \oplus \oplus \ominus \\
\text { MODERATE } 2\end{array}$ & $\begin{array}{l}\text { No clear differences in } \\
\text { cost at } 12 \text { months }\end{array}$ \\
\hline
\end{tabular}

* The risk in the intervention group (and its $95 \%$ confidence interval) is based on the assumed risk in the comparison group and the relative effect of the intervention (and its $95 \% \mathrm{Cl}$ ).

CI: confidence interval; HRQoL: health-related quality of life; RR: risk ratio; OIS: Optimal information size

\section{GRADE Working Group grades of evidence}

High quality: We are very confident that the true effect lies close to that of the estimate of the effect

Moderate quality: We are moderately confident in the effect estimate: The true effect is likely to be close to the estimate of the effect, but there is a possibility that it is substantially different

Low quality: Our confidence in the effect estimate is limited: The true effect may be substantially different from the estimate of the effect

Very low quality: We have very little confidence in the effect estimate: The true effect is likely to be substantially different from the estimate of effect

1 Downgraded due to risk of bias (two levels) - at high or unclear risk of performance bias; the use of US was not the only difference in treatment between groups

2 Downgraded due to imprecision (one level) - $95 \%$ Cls were very wide

3 Downgraded due to imprecision (one level) - very short follow-up time

4 Only 5 participants reached the endpoint (complete ulcer healing) and 4 of them were in the intervention group

5 Downgraded due to risk of bias (one level) - most studies at high or unclear risk of bias

6 Downgraded due to imprecision (one level) - 95\% Cls were wide with only 122 participants reaching the endpoint

7 Downgraded due to imprecision (one level) - only 111 participants across the three trials reached the endpoints and the OIS is hard to reach (Guyatt 2011)

8 Downgraded due to risk of bias (one level) since the outcome of healed wounds was based on nurse-reported data

9 Downgraded due to imprecision estimate (one level) - low event rate; OIS is hard to reach

$10 \mathrm{High}$ risk of healing at 12 weeks of $50 \%$ taken from a large, well conducted RCT where patients all received best practice care (Iglesias 2004). Moderate risk taken from median 
11 With best practice (i.e. high compression bandaging), a baseline risk of healing at 12 months would be approximately $80 \%$ (Iglesias 2004)

\section{Summary of findings 2 . Low frequency ultrasound compared with no ultrasound for people with venous leg ulcers}

Low frequency ultrasound compared with no ultrasound for people with venous leg ulcers

Patient or population: venous leg ulcers

Setting: any

Intervention: low frequency ultrasound

Comparison: no ultrasound

\begin{tabular}{|c|c|c|c|c|c|c|}
\hline \multirow[t]{2}{*}{ Outcomes } & \multicolumn{2}{|c|}{ Anticipated absolute effects* $(95 \% \mathrm{Cl})$} & \multirow{2}{*}{$\begin{array}{l}\text { Relative effect } \\
(95 \% \mathrm{Cl})\end{array}$} & \multirow{2}{*}{$\begin{array}{l}\text { № of partici- } \\
\text { pants } \\
\text { (studies) }\end{array}$} & \multirow{2}{*}{$\begin{array}{l}\text { Quality of the } \\
\text { evidence } \\
\text { (GRADE) }\end{array}$} & \multirow[t]{2}{*}{ Comments } \\
\hline & $\begin{array}{l}\text { Risk with no ultra- } \\
\text { sound }\end{array}$ & $\begin{array}{l}\text { Risk with Low fre- } \\
\text { quency US }\end{array}$ & & & & \\
\hline \multirow{4}{*}{$\begin{array}{l}\text { Proportion of } \\
\text { ulcers com- } \\
\text { pletely healed } \\
\text { at } 8 \text { to } 12 \text { weeks }\end{array}$} & \multicolumn{2}{|l|}{ Study population } & \multirow{4}{*}{$\begin{array}{l}\text { RR } 3.91 \\
\text { (0.47 to } 32.85)\end{array}$} & \multirow{4}{*}{$\begin{array}{l}61 \\
(2 \mathrm{RCTs})\end{array}$} & \multirow{4}{*}{$\begin{array}{l}\oplus \odot \odot \odot \\
\text { VERY LOW } 1,2\end{array}$} & \multirow{4}{*}{$\begin{array}{l}\text { There were no events in the control groups } \\
\text { so we added } 0.5 \text { to the cell as a fixed value (as } \\
\text { per Cochrane Handbook). Highly uncertain } \\
\text { whether low frequency ultrasound affects } \\
\text { healing at } 8 \text { to } 12 \text { weeks. }\end{array}$} \\
\hline & 17 per 1000 & $\begin{array}{l}65 \text { per } 1000 \\
(8 \text { to } 548)\end{array}$ & & & & \\
\hline & \multicolumn{2}{|l|}{$\mathrm{High}^{3}$} & & & & \\
\hline & 300 per 1000 & $\begin{array}{l}1000 \text { per } 1000 \\
(141 \text { to } 1000)\end{array}$ & & & & \\
\hline Adverse events & \multicolumn{2}{|c|}{ No study reported adverse events } & & & & $\begin{array}{l}\text { Pain was reported; however, this does not ap- } \\
\text { pear to have been measured systematically. }\end{array}$ \\
\hline HRQoL & \multicolumn{2}{|c|}{ No study reported HRQoL } & & & & \\
\hline Cost & \multicolumn{2}{|c|}{ No study reported cost } & & & & \\
\hline
\end{tabular}

*The risk in the intervention group (and its $95 \%$ confidence interval) is based on the assumed risk in the comparison group and the relative effect of the intervention (and its $95 \% \mathrm{Cl}$ ).

CI: confidence interval; HRQoL: health-related quality of life; RR: risk ratio; OIS: Optimal information size

\section{GRADE Working Group grades of evidence}

High quality: We are very confident that the true effect lies close to that of the estimate of the effect

Moderate quality: We are moderately confident in the effect estimate: The true effect is likely to be close to the estimate of the effect, but there is a possibility that it is substantially different

Low quality: Our confidence in the effect estimate is limited: The true effect may be substantially different from the estimate of the effect

Very low quality: We have very little confidence in the effect estimate: The true effect is likely to be substantially different from the estimate of effect 
Downgraded due to risk of bias (one level) because both studies were at unclear or high risk

Downgraded due to imprecision (two levels): the OIS is hard to reach; very wide $95 \%$ Cls - ranging in the ultrasound group from a $53 \%$ reduction of risk for ulcer healing to a

$285 \%$ increased risk (Guyatt 2011)

With best practice (i.e. high compression bandaging), a baseline risk of healing at 10 weeks (midpoint of 8 and 12 weeks) would be approximately $30 \%$ (Iglesias 2004 ) 


\section{B A C K G R O U N D}

\section{Description of the condition}

A venous leg ulcer can be defined as "an open sore in the skin of the lower leg due to high pressure of the blood in the leg veins" (British Association of Dermatologists 2010). Venous insufficiency is a term used most frequently to describe the lack of flow (stasis) of venous blood in the lower limbs. The stasis and pooling of blood in the venous system can be caused by dysfunctional valves of the superficial or deep venous system, deep venous outflow obstruction, or failure of the muscular pump mechanism of the lower limbs (Valencia 2001). The exact pathophysiology behind skin damage and ulcer formation in venous insufficiency is not known; multiple hypotheses include white cell trapping, growth factor trapping, pericapillary fibrin cuffs and fibrinolytic abnormalities (Valencia 2001).

The prevalence of active venous leg ulceration has been variously estimated as 0.29 per 1000 population ( $95 \%$ confidence interval 0.25 to 0.33 per 1000) (Hall 2014), and $1 \%$ of the adult population in the western world (Donnelly 2009). Leg ulcers are more common among women and prevalence increases with age (Callam 1985; Margolis 2002), reaching up to 3\% in adults aged 65 years and over (Donnelly 2009). The incidence of venous ulceration in the elderly population has been estimated at $0.76 / 100$ person-years for men, and 1.42/100 person-years for women (Margolis 2002).

Active ulceration is known to have a profoundly detrimental effect upon quality of life, inflicting significant pain and restriction in mobility, which result in limitations of physical and social roles (Carradice 2011; Michaels 2009). Typically, ulcers produce exudate, reduce mobility and can incapacitate, causing social isolation (Graham 2003). Reported healing times vary, but are often long; sometimes healing takes many years. One large trial found that even with treatment and close monitoring, only $65 \%$ of ulcers healed within 24 weeks, and only around $90 \%$ within three years (Barwell 2004). Once healed, recurrence is frequent, with recurrence rates of $26 \%$ to $70 \%$ within the year after healing (Barwell 2004). Ulcer management is costly due to the need for frequent changes of dressing, home visits, and hospitalisation (Olin 1999). The financial cost of treating an unhealed leg ulcer in the UK has most recently been estimated at around GBP 1700 per year (price year 2012) (Ashby 2014); and venous leg ulcers alone have been estimated to cost between GBP 300 million and GBP 600 million per year in health expenditure (Posnett 2008). Younger people of working age also experience venous leg ulcers (Nelzen 1994), and their reduced ability to participate in the labour market adds to the economic impact of this disease (Lafuma 1994; Ruckley 1997).

\section{Description of the intervention}

The effects of therapeutic ultrasound have been explored in a diverse array of conditions including fractures (Busse 2009), osteoarthritis (Robinson 2001), rheumatoid arthritis (Casimiro 2002), ankle sprains (Van der Windt 2002), pelvic and perineal pain (Hay-Smith 1998) and pressure ulcers (Akbari Sari 2006). Therapeutic ultrasound has been proposed as a solution for venous leg ulcers that are difficult to treat, and a systematic review is required in order to summarize the results of existing studies accurately.
A typical therapeutic ultrasound device consists of a generator that is linked to an applicator head; this enables delivery of multiple frequencies in a continuous, or pulsed, manner. Ultrasound is administered directly, by application of the applicator head to the skin, usually with a coupling agent (direct ultrasound) (Hart 1998), or indirectly, where the affected area is placed in a constanttemperature water bath and the ultrasound administered through the water. Directly-applied ultrasound is usually applied to the skin around the ulcer (periulcer skin) rather than directly to the ulcer. Most trials in venous leg ulcers use a pulsed ultrasound, with a frequency range of $1 \mathrm{MHz}$ to $3 \mathrm{MHz}$, and intensity of $0.5 \mathrm{~W} / \mathrm{cm}^{2}$ to $1 \mathrm{~W} / \mathrm{cm}^{2}$, for a duration of five to 10 minutes, although there does not seem to be any evidence base for this particular regimen (Hart 1998).

\section{How the intervention might work}

The effects of therapeutic ultrasound are classified as either thermal or non-thermal on the basis of the proposed physiological effects (Baker 2001; Dyson 1987; Johns 2002; Ter Haar 1999). Careful choice of the exposure time, intensity and continuous movement of the ultrasound applicator are described as important factors to consider in the delivery of therapeutic ultrasound (McCulloch 2010).

\section{Thermal effects}

The thermal effects of ultrasound are achieved by using a higher intensity application to achieve, and maintain, a rise in tissue temperature to around $40^{\circ} \mathrm{C}$ (Dyson 1987). Thermal effects have been hypothesised as being capable of increasing blood flow (Dyson 1987), although some trials concluded that there was no obvious effect (Hansen 1973; Hogan 1982; Paul 1955). It has been suggested that the thermal effects of ultrasound produce favourable changes in the physical attributes of collagen-rich structures (Dyson 1987; Ter Haar 1999).

\section{Non-thermal effects}

The non-thermal effects of ultrasound are thought to be due to two ultrasound-induced phenomena:

- acoustic streaming: flow and displacement of particles in a fluid medium due to the physical forces of sound waves (Baker 2001; Johns 2002; Ter Haar 1999). Streaming can be further classified into bulk streaming or microstreaming, the latter being more powerful mechanically.

- cavitation: the formation and behaviour of microenvironmental gases within a fluid medium under the influence of sound waves (Baker 2001; Johns 2002; Ter Haar 1999).

Many in vitro studies investigating the non-thermal effect of therapeutic ultrasound on the different elements of tissue healing have been conducted. Ultrasound has been reported as: potentiating enzymatic fibrinolysis (Francis 1992; Olsson 1994); stimulating protein synthesis (Doan 1999; Ross 1983; Webster 1978); inducing cell proliferation (Doan 1999); inducing release of preformed substances from cells (Ito 2000; Young 1990a); stimulating inflammatory cells (Maxwell 1994; Young 1990a); increasing deposition of collagen (Byl 1992); and promoting formation of new blood vessels (angiogenesis) (Young 1990b). It is not clear, however, whether these effects can be reproduced in vivo, and, while some argue that the biophysical phenomena (cavitation 
and acoustic streaming) do not occur in vivo (Baker 2001), there are conflicting results from different studies (Carstensen 2000; Ter Haar 1981). Furthermore, another study had extreme difficulty in observing the occurrence of these phenomena reliably (Crum 1992). Further analysis and discussion of this issue is out with the scope of this review, but additional information can be found in the following reviews (Baker 2001; Johns 2002).

\section{Why it is important to do this review}

The effectiveness of ultrasound in enhancing the healing of tissue both in vivo and in vitro is uncertain. The delivery of ultrasound requires investment of health resources and patient time, and the equipment can be a potential vector for hospitalacquired (nosocomial) infection (Schabrun 2006), therefore, we need to establish whether ultrasound speeds the healing of venous ulcers. In the face of these uncertainties, an up-to-date review investigating the possible therapeutic effects of ultrasound in venous leg ulcers is important.

\section{O B JE C T IVES}

To determine whether venous leg ulcers treated with ultrasound heal more quickly than those not treated with ultrasound.

\section{METHODS}

\section{Criteria for considering studies for this review}

\section{Types of studies}

We included randomised controlled trials (RCTs) that evaluated the effectiveness of ultrasound therapy on the healing of venous leg ulcers. An earlier version of the review included quasi-randomised studies, but we now deem these to be at high risk of selection bias and their results to be potentially misleading, and so have excluded them.

\section{Types of participants}

We included trials involving people of any age, and in any care setting, who were described as having leg ulcers of venous aetiology. As the method of obtaining a differential diagnosis of the ulcer varies, we used study authors' definitions of what constituted a venous leg ulcer.

Trials that recruited people with arterial, diabetic or rheumatoid ulceration were only included if the results for participants with venous ulcers were presented separately.

\section{Types of interventions}

The primary intervention was ultrasound. Eligible comparison interventions were 'no ultrasound' in the form of usual care, sham ultrasound, or a combination of the two, or alternative treatments.

\section{Types of outcome measures}

We list primary and secondary outcome measures below. If a trial was eligible (correct study design, population, and intervention/ comparator) but did not report a listed outcome, we contacted the study authors, where possible, in order to establish whether a relevant outcome was measured but not reported. We did not exclude studies solely on the basis of reported outcomes.
Where possible, we anticipated grouping outcomes into the following periods of time:

- short-term: up to 30 days;

- medium-term: > 30 days to 12 months;

- long-term: $\geq 12$ months.

The review authors used their judgement to decide whether statistical pooling within these time periods was appropriate.

\section{Primary outcomes}

We sought RCTs that reported objective measures of wound healing. Trialists use a range of different methods of measuring and reporting this outcome. We regard the following as the most relevant and rigorous measures of wound healing:

- time to complete wound healing (correctly analysed using survival, time-to-event approaches). Ideally the outcome would be adjusted for appropriate covariates, e.g. baseline ulcer area/ duration.

- proportion of wounds completely healed during follow-up (frequency of complete healing), within a trial time period, or at maximal follow-up. We planned to use and report authors' definitions of complete wound healing.

We also planned to analyse percentage change in ulcer surface area and rate of change of ulcer surface area, with adjustment for baseline size (we planned to contact study authors to request adjusted means when these were not presented). When change or rate of change in wound size was reported without adjustment for baseline size, we planned to document the use of the outcome in the study, but not to extract, summarize or use the data in any metaanalysis.

\section{Secondary outcomes}

- Health related quality of life

- Adverse events, e.g. pain

- Costs.

\section{Search methods for identification of studies}

Search strategies we used to search the Cochrane Central Register of Controlled Trials (CENTRAL) for this update and for the previous update can be found in Appendix 1 and Appendix 2 respectively.

\section{Electronic searches}

For this third update, we searched the following databases:

- Cochrane Wounds Specialised Register (searched 19 September 2016);

- the Cochrane Central Register of Controlled Trials (CENTRAL; the Cochrane Library 2016, Issue 8);

- Ovid MEDLINE (1946 to 19 September 2016);

- Ovid MEDLINE In-Process \& Other Non-Indexed Citations (searched 19 September 2016);

- Ovid Embase (1974 to 19 September 2016);

- EBSCO CINAHL Plus (1937 to 19 September 2016).

The search strategies for Ovid MEDLINE, Ovid Embase and EBSCO CINAHL for this update can be found in Appendix 3, Appendix 4 and Appendix 5, respectively. The Ovid MEDLINE 
search was combined with the Cochrane Highly Sensitive Search Strategy for identifying randomised trials in MEDLINE: sensitivityand precision-maximizing version (2008 revision), Ovid format (Lefebvre 2011). The Embase and CINAHL searches were combined with the trial filters developed by the Scottish Intercollegiate Guidelines Network (SIGN 2015). There was no restriction by language, date or publication status.

We also searched the following clinical trials registries.

- ClinicalTrials.gov (www.clinicaltrials.gov/).

- WHO International Clinical Trials Registry Platform (apps.who.int/trialsearch/Default.aspx).

- EU Clinical Trials Register (www.clinicaltrialsregister.eu/).

\section{Searching other resources}

We evaluated guidelines from SIGN for recommendations on the use of therapeutic ultrasound for treating leg ulcers (SIGN 2010). We also searched the reference lists of guidelines and potentially useful articles for further reports of RCTs. In addition, we searched the reference lists of retrieved included trials, as well as relevant systematic reviews, meta-analyses and health technology assessment reports to identify other potentially eligible trials.

\section{Data collection and analysis}

\section{Selection of studies}

For this update, one review author (ZL) assessed the titles and abstracts of studies identified by the searches for eligibility. We obtained full reports if, from this initial assessment, they appeared to satisfy the inclusion criteria. Those rejected were checked by another review author (NC). ZL checked full text reports to identify those that were eligible for inclusion. We recorded all reasons for exclusion of studies that we obtained as full text reports. This was repeated independently by another review author (NC) to provide verification. Any disagreement was resolved by discussion.
We completed a PRISMA (Preferred Reporting Items for Systematic Reviews and Meta-Analyses) flow chart to summarise this process (Liberati 2009).

\section{Data extraction and management}

We extracted and summarised details of the studies using a data extraction sheet. If data were missing then we attempted to contact researchers to obtain the required information. All data extraction performed by one review author was checked by the other.

We extracted the following data:

- country of origin and healthcare setting of the study;

- eligibility criteria: baseline patient characteristics by treatment group;

- details of the ultrasound regimen received by the intervention group plus co interventions;

- details of the ulcer care regimen received by the comparison group;

- primary and secondary trial outcome(s);

- results including primary and secondary outcomes, adverse events, numbers of withdrawals, all by treatment group.

\section{Assessment of risk of bias in included studies}

Two review authors independently assessed each included study, without blinding to journal or authorship, using the Cochrane tool for assessing risk of bias (Higgins 2011). This tool addresses six specific domains, namely sequence generation, allocation concealment, blinding, incomplete outcome data, selective outcome reporting and other issues (e.g. extreme baseline imbalance) (see Appendix 6 for details of assessment criteria). We assessed blinding and completeness of outcome data separately for each outcome. We completed a risk of bias table for each eligible study. Both review authors discussed any disagreement to achieve a consensus (see Figure 1).

\section{Figure 1. Methodological quality graph: review authors' judgements about each methodological quality item} presented as percentages across all included studies.

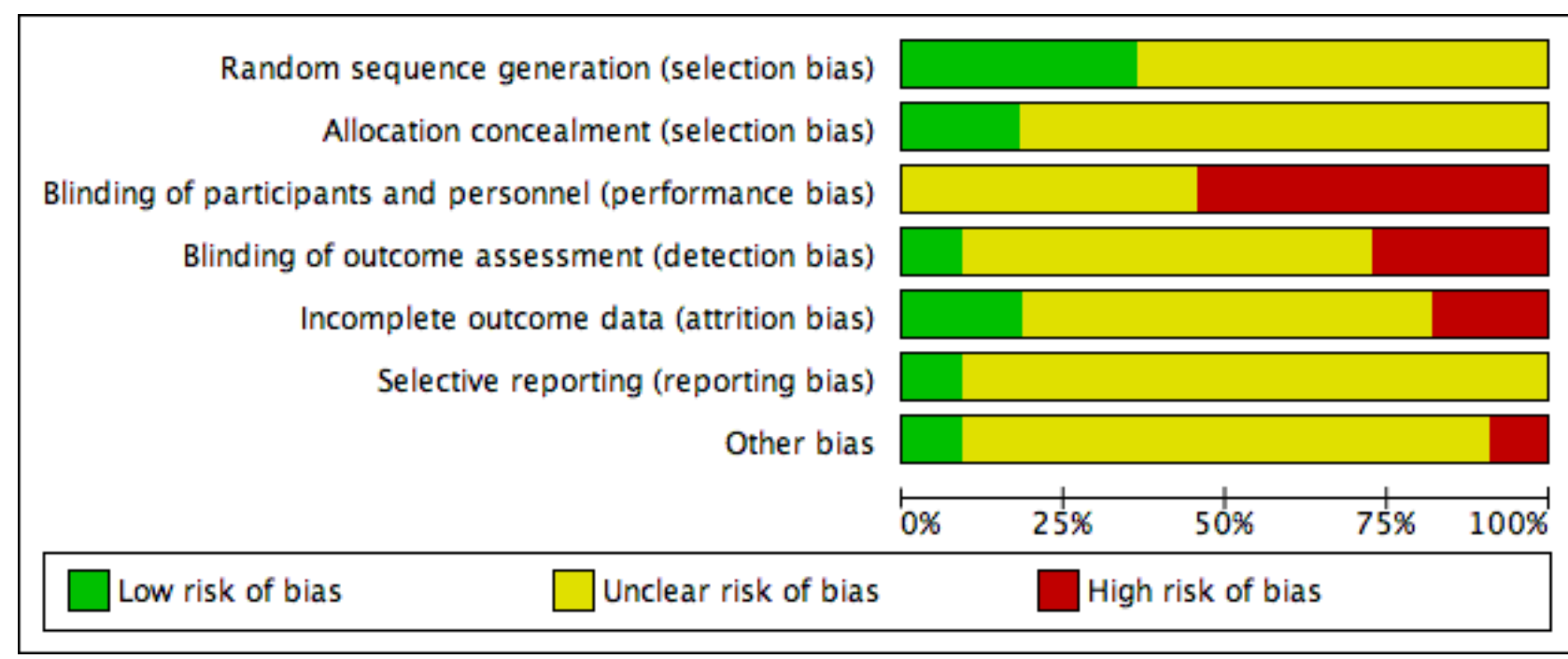

We present an assessment of risk of bias using a 'Risk of bias' summary figure (Figure 2), which presents all of the judgments in a cross-tabulation of study by entry. This display of internal validity indicates the weight the reader may give the results of each 
study. Studies were classed as being at high risk of bias if they were rated as 'high risk' for any of the four key criteria (random sequence generation, allocation concealment, blinding of outcome assessment and incomplete outcome data addressed) and they were classed as being at 'unclear risk' if they had at least one unclear criterion, with the remainder classed as 'low risk'. 
Figure 2. Methodological quality summary: review authors' judgements about each methodological quality item for each included study.

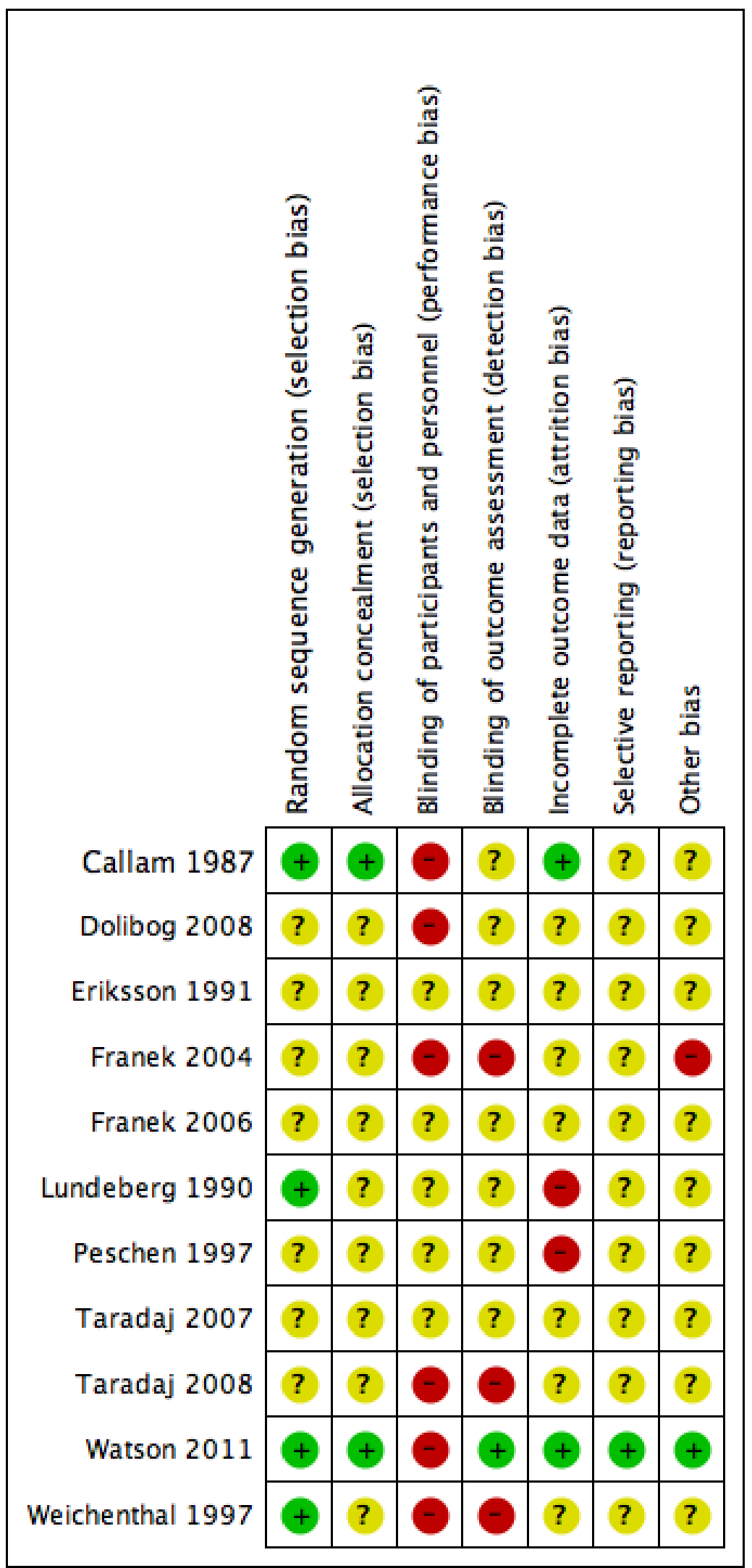




\section{Measures of treatment effect}

For dichotomous outcomes we calculated the risk ratio (RR) with $95 \%$ confidence intervals $(\mathrm{Cl})$. For continuous outcomes that used the same assessment scale we used the mean difference (MD) with $95 \% \mathrm{Cls}$. If trials used different assessment scales, we used the standardised mean difference (SMD) with $95 \% \mathrm{Cls}$. We only considered mean or median time to healing without survival analysis as a valid outcome if reports specified that all wounds healed. Time-to-event data (e.g. time-to-complete wound healing) were reported as hazard ratios (HR) where possible, in accordance with the methods described in the Cochrane Handbook for Systematic Reviews of Interventions (Deeks 2011). If studies reporting time-to-event data (e.g. time to healing) did not report a hazard ratio, then, where feasible, we planned to estimate this using other reported outcomes, such as the number of events, through the application of available statistical methods (Parmar 1998).

For dichotomous outcomes we also present absolute risk differences in the Summary of findings for the main comparison and Summary of findings 2. Hoffrage and colleagues suggested that physicians' inferences about statistical outcomes are more appropriate when they deal with 'natural frequencies' - whole numbers of people, both treated and untreated, than when effects are presented as percentages (Hoffrage 2000). In this case, we presented our outcomes as anticipated absolute effects.

\section{Unit of analysis issues}

Where studies randomised participants and reported outcomes for wounds, and the number of wounds appeared to be equal to the number of participants, we treated the participant as the unit of analysis.

We had anticipated a possible unit of analysis issue if: individual participants with multiple wounds were randomised; the allocated treatment was used on multiple wounds per participant (or perhaps only on some participants); and if data were presented and analysed by wound not person. This is a type of clustered data and presents a unit of analysis error that inflates precision. In cases where included studies contained some or only clustered data, we planned to report this alongside whether data had been (incorrectly) treated as independent. We recorded this as part of the 'Risk of bias' assessment. We did not plan to undertake further calculation to adjust for clustering.

\section{Dealing with missing data}

High rates of withdrawal from trials are common in chronic wounds research, and trialists have tended to exclude withdrawn and 'lost' participants from analysis. This approach clearly disrupts randomisation, and has a high potential for introducing bias largely by ignoring participants who have failed to heal. For the main analysis we have, therefore, regarded participants who were lost to follow-up (i.e. randomised but do not appear in the analysis) as unhealed - where healing was the main endpoint - as this seems the most plausible outcome, however, we have also tested this approach by conducting complete case analyses (see Analysis 1.2; Analysis 1.3).

Since in a time-to-healing analysis that uses survival analysis methods, drop-outs are accounted for as censored data, we took no action regarding missing data.
For continuous variables, for example, cost and for all secondary outcomes, we presented available data from the study reports or study authors and did not anticipate imputing missing data. We calculated missing measures of variance where possible. If calculation was not possible, we contacted the study authors. Where these measures of variation were not available, we excluded the study from any meta-analyses.

We did not specify application and comparison of these two approaches in the original protocol.

\section{Assessment of heterogeneity}

Assessment of heterogeneity can be a complex, multi-faceted process. Firstly, we planned to consider clinical and methodological heterogeneity, that is the degree to which the included studies varied in terms of participants, interventions, outcomes and characteristics such as length of follow-up. We supplemented this assessment of clinical and methodological heterogeneity with information regarding statistical heterogeneity gained by using the $\mathrm{Chi}^{2}$ test (we would consider a significance level of $\mathrm{P}<0.10$ to indicate statistically significant heterogeneity) in conjunction with the $1^{2}$ measure (Higgins 2003). $\left.\right|^{2}$ examines the percentage of total variation across RCTs that is due to heterogeneity rather than chance (Higgins 2003). Very broadly, we consider that $I^{2}$ values of $25 \%$ or less may mean a low level of heterogeneity (Higgins 2003), and values of $75 \%$ or more indicate very high heterogeneity (Deeks 2011). Where there was evidence of high heterogeneity we anticipated exploring this further where possible: see Data synthesis.

\section{Assessment of reporting biases}

Most reporting biases will be avoided by not restricting the literature search to published literature or by language and date. Due to the limited numbers of included studies, we were unable to investigate publication bias using a funnel plot.

\section{Data synthesis}

We combined the studies included in the review by narrative overview, with meta-analysis of appropriate data conducted with Review Manager 5.3 software (RevMan 2014). We planned to assess clinical and methodological heterogeneity and anticipated pooling data when studies appeared similar in terms of intervention type, duration of follow-up and outcome type. In terms of a metaanalytical approach, in the presence of clinical heterogeneity (review author judgement), or evidence of statistical heterogeneity, or both, we used a random-effects model. We planned to use a fixed-effect approach only when clinical heterogeneity was thought to be minimal and statistical heterogeneity was estimated as non-statistically significant for the $\mathrm{Chi}^{2}$ value and $0 \%$ for the $\mathrm{I}^{2}$ assessment (Higgins 2003).

For dichotomous outcomes we present the summary estimate as a risk ratio (RR) with $95 \% \mathrm{Cl}$. Where continuous outcomes were measured in the same way across studies, we planned to present a pooled difference in means (MD) with $95 \% \mathrm{Cl}$; we planned to pool standardised mean difference (SMD) estimates where studies measured the same outcome using different methods. For time-toevent data, we planned to plot (and, if appropriate, pool) estimates of hazard ratios and $95 \% \mathrm{Cls}$ as presented in the study reports using the generic inverse variance method in RevMan 5.3. Where time to healing was analysed as a continuous measure, but it was not clear 
if all wounds healed, we planned to document use of the outcome in the study, but not to summarize or use the data in any metaanalysis.

The studies are categorised into those delivering high or low frequency ultrasound (high frequency being $1 \mathrm{MHz}$ and low frequency being $30 \mathrm{kHz}$ ). We compiled two 'Summary of findings' tables using GRADEpro (GRADEpro GDT 2015); one each for high frequency and low frequency ultrasound. We estimated control group event rates for patients at medium risk of healing using the average risk of healing in the included studies; we estimated control group event rates for patients at high risk of healing from a large, well conducted trial that exposed participants to best practice (Iglesias 2004).

\section{Sensitivity analysis}

We planned to undertake sensitivity analysis to test the impact of different assumptions regarding the outcomes of participants who were lost to follow up, specifically regarding losses as unhealed compared with regarding losses as healed.

\section{RES U LTS}

\section{Description of studies}

See Characteristics of included studies; Characteristics of excluded studies

\section{Results of the search}

The initial version of this review included seven studies (Flemming 2000). The first update added one new study (Franek 2004). The second update, Cullum 2010, added two new studies: Dolibog 2008 and Taradaj 2008. Two studies that were originally included were not randomised and so have now been excluded (Dyson 1976; Roche 1984). The literature search for this 2016 update yielded 66 abstracts that we screened for eligibility. We obtained these 66 reports (for 65 studies) for a more detailed assessment and included three new studies (Franek 2006; Taradaj 2007; Watson 2011) which brings the total number of included studies to 11 . One further potentially eligible study (White 2016) is awaiting assessment (Figure 3).

\section{Figure 3. Study flow diagram}

\section{8 studies included in previous version of review}

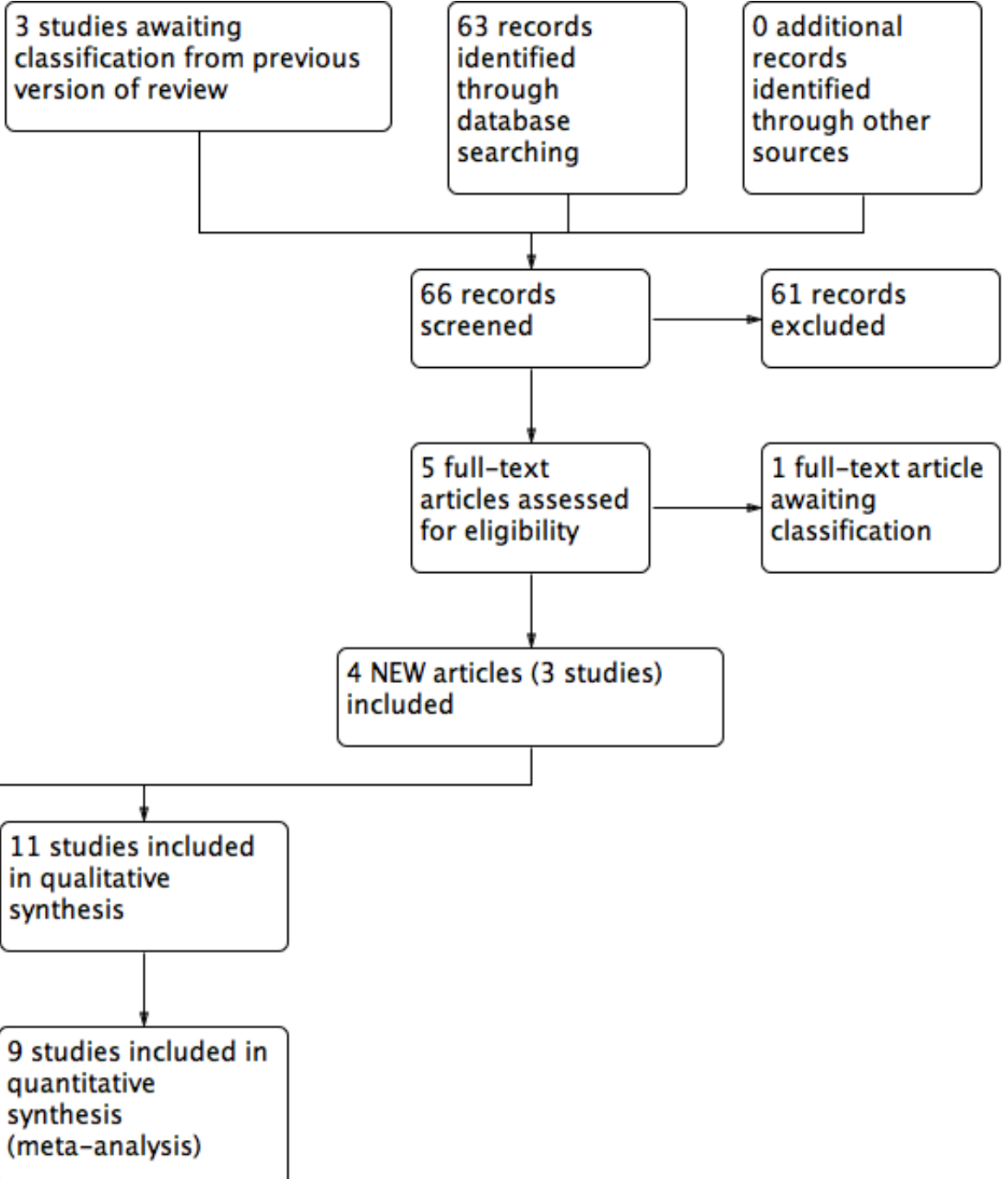




\section{Included studies}

\section{Design}

This 2016 update includes a total of 11 RCTs, and a total of 969 participants. Most included studies had two arms; two studies had three arms (Franek 2004; Taradaj 2007), and another two had four arms (Franek 2006; Taradaj 2008). Two studies were undertaken in Germany (Peschen 1997; Weichenthal 1997), two in Sweden (Eriksson 1991; Lundeberg 1990), five in Poland (Dolibog 2008; Franek 2004; Franek 2006; Taradaj 2007; Taradaj 2008), and two in the UK (Callam 1987; Watson 2011). Ten studies had follow-up periods of 12 weeks or less, and only one had a 12-month followup (Watson 2011). The included RCTs were reported between 1987 and 2011.

\section{Sample sizes}

Most of the included studies were small; sample sizes ranged from 24 to 337 participants. All participants were diagnosed with venous leg ulceration, though only six out of 11 trials reported the criteria by which this diagnosis was made (Dolibog 2008; Eriksson 1991; Peschen 1997; Taradaj 2008; Watson 2011; Weichenthal 1997).

\section{Setting}

The setting in which the trial was undertaken was stated for seven studies: a physiotherapy department (Callam 1987); hospital and primary care (Eriksson 1991); hospitals (Franek 2004; Franek 2006); outpatient clinics (Peschen 1997; Weichenthal 1997); a range of services including community nurse services, community leg ulcer clinics, and hospital outpatient leg ulcer clinics (Watson 2011). The remaining four RCTs did not report the setting.

\section{Participants}

The mean age of participants ranged from 59 years to 70 years. The proportion of female participants ranged from $55 \%$ to $79 \%$.

\section{Interventions}

Therapeutic ultrasound was compared with sham or placebo ultrasound in three trials (Eriksson 1991; Lundeberg 1990; Peschen 1997), and in the remaining eight it was compared with standard ulcer care. Four trials evaluated directly-applied ultrasound (Callam 1987; Eriksson 1991; Lundeberg 1990; Watson 2011), and the other seven evaluated ultrasound that was applied indirectly though water. Nine trials evaluated high-frequency therapeutic ultrasound (Callam 1987; Dolibog 2008; Eriksson 1991; Franek 2004; Franek 2006; Lundeberg 1990; Taradaj 2007; Taradaj 2008; Watson 2011), while the other two evaluated low-frequency ultrasound.

\section{Outcomes}

Wound healing trialists vary hugely in their selection and reporting of outcome measures, and there is very little methodological research to validate the wound outcome measures used. Arguably, time to wound healing is the most patient-oriented outcome, since, even in trials of treatments for chronic wounds, the majority do achieve healing. Survival analysis is the most appropriate strategy for analysing a time-to-event outcome such as time-tohealing, with hazard ratio as the effect measure; however, this is very rarely used. Three trials used life table methods to compare healing rates (Callam 1987; Lundeberg 1990; Peschen 1997), but did not undertake any adjustment for imbalances and did not report hazard ratios, whilst Watson 2011 conducted full survival analysis, implemented the Cox proportional hazards model and reported the hazard ratio. Eight trials reported the proportion of ulcers completely healed at arbitrary and varying follow-up times (duration of follow-up ranged from three weeks in Franek 2004 to 12 weeks in Callam 1987, Lundeberg 1990, and Peschen 1997); the remaining four trials reported healing by seven or eight weeks (Callam 1987; Dolibog 2008; Lundeberg 1990; Watson 2011). Watson 2011 reported median time to healing and the hazard ratio, but on request also supplied proportions of participants with healed ulcers at eight weeks, 12 weeks and 12 months. Franek 2006 and Taradaj 2007 only provided data on change in ulcer size at four and seven weeks respectively, without any healed data available.

Only one study, Watson 2011, measured and reported healthrelated quality of life, adverse events and costs. Several trials reported numbers of withdrawals due to pain or bleeding, and mentioned some adverse events; these have been described in narrative form alongside the trial results however only Watson 2011 appears to have had robust and systematic adverse event reporting and recording procedures in place.

\section{Excluded studies}

We excluded six studies from the review (see Characteristics of excluded studies). The main reasons for exclusion were:

- not a randomised controlled trial (five studies; Dissemond 2003; Dyson 1976; Kavros 2007b; Roche 1984; Tan 2007)

- study mainly included people with ulcers due to arterial rather than venous disease (one study; Kavros 2007a).

\section{Risk of bias in included studies}

We deemed seven out of the 11 studies to be at a high risk of bias (Callam 1987; Dolibog 2008; Franek 2004; Lundeberg 1990; Peschen 1997; Taradaj 2008; Weichenthal 1997); we rated Eriksson 1991, Franek 2006, and Taradaj 2007 as being at an unclear risk of bias for every criterion, and Watson 2011 as being at a low risk for every criterion except for performance bias (for which it was high risk) (see Figure 1; Figure 2 for a summary of the risk of bias judgements).

\section{Allocation}

\section{Adequacy of randomisation process}

All study authors stated that the participants were randomised. Four studies provided sufficient information to indicate that participants were randomised according to an adequate randomisation sequence. Weichenthal 1997 used computergenerated random numbers, Lundeberg 1990 and Callam 1987 used randomised permuted blocks, and Watson 2011 used computerised randomisation with varying block sizes of four and six participants. The randomisation method was not described in the remaining seven studies (Dolibog 2008; Eriksson 1991; Franek 2004; Franek 2006; Peschen 1997; Taradaj 2007; Taradaj 2008).

\section{Allocation concealment}

Callam 1987 and Watson 2011 used a central office to conceal allocation and were the only included studies to describe concealed allocation adequately; we rated the other studies as being at unclear risk of bias for allocation concealment. 


\section{Blinding}

Studies that we classified as being at a high risk of performance bias reported that blinding of care providers to the allocation was not possible, because of the appearance of the ultrasound intervention (Callam 1987; Dolibog 2008; Franek 2004; Taradaj 2008; Watson 2011; Weichenthal 1997). Three studies used sham ultrasound (Eriksson 1991; Lundeberg 1990; Peschen 1997); it was unclear whether healthcare personnel were blinded, as they may have been responsible for setting the ultrasound machine. Franek 2006 and Taradaj 2007 did not report information that helped us to judge their risk of performance bias and were therefore judged as being at unclear risk of bias.

Determination of whether a wound has healed or not involves judgement, and thus can be influenced by an assessor's knowledge of the treatment allocation. No study reported what could be regarded as a fully blinded outcome assessment. In three studies (Callam 1987; Eriksson 1991; Lundeberg 1990), ulcer tracings were completed by unblinded staff, but the analysis (computer-aided measurement of ulcer area) of coded tracings was undertaken by staff who were blinded to treatment group. In Watson 2011, photographs were taken by unblinded staff and healing judged from the photographs by assessors who were blinded to treatment allocation: we rated this as being at a low risk of detection bias. We judged blinding of outcome assessment to have been highly unlikely in three studies (Franek 2004; Taradaj 2008; Weichenthal 1997). Two trials did not provide sufficient information for us to judge whether outcome assessment was blinded (Dolibog 2008; Peschen 1997), and another two trials did not report any blinding of outcome assessment (Franek 2006; Taradaj 2007). These four trials were classified as being at unclear risk of bias.

\section{Incomplete outcome data}

Twenty-four per cent of 108 participants in Callam 1987 and 9\% of 337 participants in Watson 2011 were lost to follow-up, but these two trials conducted final analysis on the basis of the intentionto-treat approach.These two studies were classified as being at a low risk of attrition bias. We rated seven trials as unclear for risk of attrition bias (Dolibog 2008; Eriksson 1991; Franek 2004; Franek 2006; Taradaj 2007; Taradaj 2008; Weichenthal 1997); two studies appear to have omitted non-adherent participants from their analyses and we rated them as being at high risk of attrition bias (Lundeberg 1990; Peschen 1997).

\section{Selective reporting}

We deemed 10 studies to be at unclear risk of reporting bias, and one to be at low risk of reporting bias, as the protocol for this study was fully available and all outcomes had been reported (Watson 2011).

\section{Other potential sources of bias}

The results of Franek 2004 should be viewed with extreme caution, as the treatment groups differed in important aspects of care apart from the ultrasound treatment. The non-ultrasound group received an intensive wound treatment regimen that was not given to the two ultrasound groups, and, furthermore, while participants in the two ultrasound groups were admitted to the same hospital, the non-ultrasound group were admitted to a different hospital.

\section{Effects of interventions}

See: Summary of findings for the main comparison High frequency ultrasound compared with no ultrasound for people with venous leg ulcers; Summary of findings $\mathbf{2}$ Low frequency ultrasound compared with no ultrasound for people with venous leg ulcers

There was much heterogeneity in the nature and timing of outcomes reported across all trials. Trialists reported a combination of the number of ulcers healed at specified (and varied) time points, mean change in ulcer size at varied time points, or both.

\section{Comparison 1: High-frequency ultrasound compared with standard care/sham ultrasound (nine studies, 908 participants)}

Nine RCTs, with a total of 908 randomised participants, evaluated high-frequency ultrasound (Callam 1987; Dolibog 2008; Eriksson 1991; Franek 2004; Franek 2006; Lundeberg 1990;Taradaj 2007; Taradaj 2008; Watson 2011). The Franek 2006 and Taradaj 2007 studies did not report ulcer healing data, but the remaining seven studies (743 participants) did. The Franek 2004 study reported numbers of ulcers healed, and mean and median change in ulcer area at three weeks only. The Taradaj 2008 and Dolibog 2008 studies reported healing at seven weeks; the Eriksson 1991, Callam 1987 and Lundeberg 1990 studies reported healing at eight weeks and we obtained 8 week healing data for the Watson 2011study. Callam 1987, Lundeberg 1990 and Watson 2011 also reported ulcers healed at 12 weeks.

\subsection{Primary outcome: ulcer healing}

\subsubsection{Ulcer healing at three weeks (one trial; 43 participants)}

The results of Franek 2004 should be viewed with extreme caution for several reasons; apart from the paucity of endpoint data due to the brief follow-up, the trial arms received systematically different co interventions and the study was likely to be subject to important performance bias. We have included it here since we did not pre specify that we would exclude trials where ultrasound was not the only systematic difference in treatments. The trial involved three treatment arms: two ultrasound arms $\left(1 \mathrm{~W} / \mathrm{cm}^{2}\right.$ and $0.5 \mathrm{~W} / \mathrm{cm}^{2}$ ) and a control arm with no ultrasound. However, the control group received co interventions (in the form of local wound treatments) that were not received by the ultrasound groups (potassium permanganate and wet dressings of $0.1 \mathrm{M}$ copper sulphate solution plus compresses of fibrolan, chloramphenicol, colistin, and gentamicin), and were treated in a different hospital. At three weeks, complete healing had occurred in $1 / 22(4.5 \%)$ of the group receiving $1 \mathrm{~W} / \mathrm{cm}^{2}$ ultrasound, $3 / 21$ (14.3\%) of the group receiving $0.5 \mathrm{~W} / \mathrm{cm}^{2}$ ultrasound, and $1 / 22(4.5 \%)$ of people receiving no ultrasound. For the purposes of the main analysis we have pooled both ultrasound arms and compared them with no ultrasound. This preserves randomisation, but results in unequally sized groups. There was no clear difference in the proportion of ulcers healed with ultrasound compared with no ultrasound at three weeks (RR 2.05, 95\% Cl 0.24 to 17.23; Analysis 1.1). Using the GRADE approach, we judged the quality of evidence for this result to be very low (downgraded twice for risk of bias given the problems of design and twice for extreme imprecision); see Summary of findings for the main comparison. 


\subsubsection{Ulcer healing at seven to eight weeks (six trials; 678 participants)}

We pooled the results for Callam 1987; Dolibog 2008; Eriksson 1991; Lundeberg 1990; Taradaj 2008 and Watson 2011 for seven to eight weeks' follow-up as statistical heterogeneity was low $\left(1^{2}=13 \%\right)$. We regarded those randomised but lost to follow-up as unhealed in this analysis (i.e. they appeared in the denominator only). After seven to eight weeks of ultrasound treatment, on average, there was no evidence of a difference in the proportion of ulcers healed with ultrasound compared with no ultrasound (pooled RR 1.21, $95 \% \mathrm{Cl} 0.86$ to $1.71 ; \mathrm{I}^{2}=13 \%$; Analysis 1.2 ) (we used a randomeffects model, which was possibly the more appropriate approach given the differences between the trials). When this analysis was undertaken using a fixed-effect model, the estimate remained similar (RR $1.19,95 \% \mathrm{Cl} 0.87$ to 1.62 , not shown). We judged this to be low quality evidence; we downgraded once for high or unclear risk of bias and once for imprecision.

\subsubsection{Ulcer healing at 12 weeks (three trials; 489 participants)}

We pooled the data from three studies using the fixed-effect model, as there was no statistical heterogeneity $(12=0)$ (Callam 1987; Lundeberg 1990; Watson 2011). There was no evidence of a difference in healing at 12 weeks between participants treated with ultrasound and those treated without ultrasound (RR 1.26, 95\% Cl 0.92 to 1.73; fixed-effect; Analysis 1.3). We regarded both Callam 1987 and Lundeberg 1990 as being at high risk of detection bias for healing outcomes (due to non-blinding of outcome assessment). We regarded Watson 2011 as being at low risk for all criteria. We judged the quality of evidence to be moderate; we downgraded once for imprecision - Summary of findings for the main comparison.

\subsubsection{Ulcer healing at 12 months (one trial; 337 participants)}

We also obtained 12-month healing data from the authors of Watson 2011 (maximal follow-up in this study), who told us that $72 / 168$ people $(43 \%)$ healed with ultrasound at 12 months compared with $78 / 169(46 \%)$ who received standard care alone (RR $0.93,95 \% \mathrm{Cl} 0.73$ to 1.18 ; Analysis 1.4). Meanwhile, fitting the Cox proportional hazard regression model with a centre frailty parameter resulted in a hazard ratio of ultrasound versus standard care of $0.99(95 \% \mathrm{Cl} 0.70$ to 1.40$)(\mathrm{P}=0.97)$, adjusted for log (area), $\log$ (duration) and ulcer compression. This indicated that there was no current evidence of an effect of ultrasound treatment on the hazard of healing after adjustment for prespecified prognostic factors and treatment centre.We judged this to be low quality evidence; we downgraded once for unclear risk of bias and once for imprecision.

\subsection{Primary outcome: change in ulcer size}

The Franek 2006 study reported only unadjusted data for change in ulcer size; there was a greater reduction in mean percentage ulcer area for the ultrasound group compared with the control group (relative to baseline) at four weeks $(P=0.007)$ (Table 1). The Taradaj 2007 study provided data on change in ulcer size only; it reported the mean percentage change in ulcer area (relative to baseline) at seven weeks and found no significant difference between the ultrasound and control groups $(P>0.05)$.

\subsection{Secondary outcomes}

\subsubsection{Adverse events}

Watson 2011 reported outcomes for all 337 randomised participants, and reported data from participants who withdrew from the trial in the final analysis. The study reported a total of 88 serious adverse events (SAEs) experienced by 64 participants: $29(45 \%)$ in the standard care group and $35(55 \%)$ in the ultrasound group. The SAEs included death, life threatening risk, hospitalisation, persistent or significant disability, and new diagnosis as diabetic. There were 445 non-serious adverse events in 153 participants: 67 participants (44\%) in the standard care group and 86 participants $(56 \%)$ in the ultrasound group. Significantly more people receiving ultrasound experienced adverse events than those receiving standard care (from original trial report, as analysed by random-effects negative binomial regression); most were non-serious (Watson 2011). We judged the quality of evidence to be moderate; we downgraded once for imprecision - Summary of findings for the main comparison.

In Callam 1987 a total of 26/108 (24\%) randomised participants withdrew, leaving $76 \%$ of those randomised to provide outcome data. Proportions and reasons for withdrawal were similar across the two treatment groups: $11 / 52(21 \%)$ withdrew from the ultrasound group because of allergy (four), pain (four), death (two), and withdrawn consent (two); 15/56 (27\%) withdrew from the standard care group for reasons of allergy (six), pain (three), deterioration (two), withdrawal of consent (three), and newlydiagnosed arterial disease (one).

In the Eriksson 1991 trial 7/19 (37\%) participants withdrew from the ultrasound group (three for allergy, two for pain, and two withdrew consent) compared with 6/19 (32\%) from the control group (two for allergy, one for pain, three withdrew consent).

In the Lundeberg 1990 trial, 5/22 participants (23\%) randomised to ultrasound withdrew (two for allergy, one for pain, two withdrew consent) compared with seven out of $22(32 \%)$ from the sham group (three for allergy, one for pain, three withdrew consent). Dolibog 2008, Franek 2004, Franek 2006, Taradaj 2007 and Taradaj 2008 did not report any withdrawals or adverse events.

\subsubsection{Quality of life}

Only the Watson 2011 study reported on quality of life. There was no observable change in the physical component scores (PCS) or mental component scores (MCS) of the SF-12 over 12 months' follow-up, and no observed difference between treatment groups $(n=229)$. The mean health-related quality of life (HRQoL) PCS in the intervention group was 0.96 less ( 3.17 less to 1.25 more); and the MCS in the intervention group was 2.1 more (0.97 less to 5.17 more). Participants in both groups exhibited lower mean PCS and MCS than the general population of the USA, suggesting the leg ulcer patients in this trial had lower HRQoL than the USA population of a similar age (Watson 2011). The quality of evidence was moderate, downgraded for imprecision - Summary of findings for the main comparison.

\subsubsection{Cost}

Watson 2011 also reported the outcome of cost: addition of ultrasound treatment to standard care cost, on average, GBP 197.88 more per participant per year (95\% bias-corrected Cl GBP -35.19 to GBP 420.32). This difference was not statistically significant. The quality of evidence was moderate, downgraded for imprecision Summary of findings for the main comparison. 


\section{Summary: high-frequency ultrasound compared with no ultrasound}

Current evidence suggests no clear difference in the proportion of venous ulcers healed at any time-point nor for the hazard of healing, when high-frequency ultrasound was compared with no ultrasound. There are few comparative data available at most of the follow-up time points, especially for the short-term periods. The majority of trials included were small, reported very limited outcome data and were at an unclear or high risk of bias. Only one study (newly included in this 2016 update) was conducted well methodologically and contributed usefully to this review. One small, poor quality study reported a greater mean reduction in ulcer size at four weeks in the ultrasound group compared with the control group.

\section{Comparison 2: Low-frequency ultrasound compared with} standard care or sham ultrasound (two trials; 61 participants)

Two RCTs evaluated indirectly-applied, low-frequency ultrasound. Both Peschen 1997 and Weichenthal 1997 applied ultrasound at 30 $\mathrm{kHz}, 0.1 \mathrm{~W} / \mathrm{cm}^{2}$, three times a week via a water bath. These trials reported healing outcomes at different time points (12 weeks in Peschen 1997, and eight weeks in Weichenthal 1997).

\subsection{Primary outcome: ulcer healing at eight to 12 weeks}

We pooled these two studies for the outcome of healing at eight to 12 weeks, and used a fixed-effect model as the 12 value was 0 (Analysis 2.1). These studies found no clear difference in the risk of healing associated with low-frequency ultrasound applied three times a week (RR 3.91, 95\% Cl 0.47 to 32.85 ). This result did not change appreciably when we applied a random-effects model (RR $3.85,95 \% \mathrm{Cl} 0.45$ to 32.84 , not shown), however, as there were only three ulcers healed across these two trials, this comparison is underpowered and a treatment effect cannot be excluded. We judged that the quality of evidence to be very low: we downgraded once for risk of bias due to both studies being at unclear or high risk of bias, and twice for extreme imprecision; see Summary of findings 2.

\subsection{Secondary outcomes}

Weichenthal 1997: microbleeding around the ulcer occurred in $5 / 12$ ulcers in the ultrasound group compared with none in the sham ultrasound group. Participants' experiences of pain were reported, however, this does not appear to have been measured systematically. Pain was reported as follows: in the ultrasound group one participant reported no change in baseline pain, eight complained of pain prior to treatment; and pain was no longer reported by any participants at the start of week four. In the sham ultrasound group one participant reported no change in baseline pain, while 10 complained of pain at various time points. There was no reporting of HRQoL or cost.

Peschen 1997: this study reported treatment-related adverse events only for participants in the ultrasound group. Eleven out of 19 participants in the ultrasound group felt no pain or mild pain on fewer than three treatment occasions; $7 / 19$ reported pain on more than two occasions, but severe pain on fewer than three treatment occasions; $1 / 19$ reported severe pain on more than two occasions. Twelve out of 19 ultrasound participants experienced erythema on more than two occasions. There was no reporting of HRQoL or costs.

Summary: Low-frequency ultrasound compared with no ultrasound at eight to 12 weeks' follow-up
Two small studies with short follow-up periods that were at an unclear of bias reported limited outcome data. These found no evidence of a difference in ulcer healing with low-frequency ultrasound compared with no ultrasound at eight to 12 weeks' follow-up.

\section{Sensitivity analyses}

Where the number randomised differed from the number analysed, we undertook the primary analysis using the numbers randomised as the denominator (i.e. assuming losses to follow-up were unhealed). We then examined the impact of this decision in a sensitivity analysis where we analysed complete cases only.

\section{High-frequency ultrasound}

The result of the sensitivity analysis for high-frequency ultrasound at seven to eight weeks for the Callam 1987, Eriksson 1991, Lundeberg 1990, Dolibog 2008, and Taradaj 2008 studies; Analysis 1.2), using a complete case analysis (Average treatment RR for healing with ultrasound $1.21,95 \% \mathrm{Cl} 0.88$ to $1.67 ; \mathrm{I}=8 \%$, randomeffects) was consistent with the result when losses were regarded as unhealed (Average treatment RR for healing with ultrasound 1.21, $95 \% \mathrm{Cl} 0.86$ to $1.71 ; 12=13 \%$, random-effects). This was also the case for results at 12-week follow-up (RR for healing with ultrasound compared with no ultrasound using a complete case analysis was $1.20,95 \% \mathrm{Cl} 0.89$ to 1.62 (I2=0\%, fixed-effect); compared with an RR of $1.26,95 \% \mathrm{Cl} 0.92$ to 1.73 ( $12=0 \%$, fixed-effect) when losses were regarded as unhealed (Analysis 1.3).

\section{Low-frequency ultrasound}

In the Peschen 1997 study, two participants were withdrawn from the control group for non-compliance, however different assumptions about the healing outcome of these two participants did not affect the results (RR for ulcer healing at 12 weeks for ultrasound compared with no ultrasound when losses regarded as unhealed $5.00,95 \% \mathrm{Cl} 0.27$ to 94.34 ; RR for ulcer healing at 12 weeks using complete case analysis $4.23,95 \% \mathrm{Cl} 0.23$ to 79.10 , not shown).

\section{'Summary of findings' tables}

We have included two 'Summary of findings' tables (Summary of findings for the main comparison; Summary of findings 2), which give an overview of the volume and quality of the evidence.

\section{DISCUSSION}

\section{Summary of main results}

This review has identified, appraised and presented all available randomised controlled trial (RCT) evidence regarding the clinical effectiveness of ultrasound in the treatment of venous leg ulcers. The review includes 11 relevant studies with a total of 969 participants. Overall the evidence was limited: most included studies were small and therefore statistically underpowered to detect treatment differences, had they existed.

The addition of a large, multicentre trial (Watson 2011) of highfrequency, therapeutic ultrasound to this review update has made no appreciable difference to the conclusions of this review; we remain uncertain as to whether high-frequency therapeutic ultrasound affects the healing rate of venous leg ulcers. The addition of a 337 participant trial, Watson 2011, to a review which hitherto contained data from only 467 randomised participants 
greatly increased the power of this review update. Furthermore, while most of the previous evidence came from trials that were deemed to be at high risk of bias, we assessed the newly added Watson 2011 study as being at low risk of bias for all domains except blinding of participants and personnel (where it was deemed to be at high risk). Thus the addition of Watson 2011 represents the inclusion of a large amount of high-quality data for which we have greater confidence than that from the previous studies.

The primary outcome for this review was complete wound healing. Though nine of the 11 included studies reported this outcome, they did so at different time-points. There was no clear evidence of a difference in the number of ulcers healed between the ultrasound and non-ultrasound groups. Most included studies were small and underpowered, and our GRADE assessment classed the estimates from this evidence as being mainly of low quality. Only at 12 weeks, there was moderate quality evidence (due to Watson 2011) showing that it was uncertain whether high frequency ultrasound affects healing.

Another primary outcome, change in wound size (adjusted for baseline size), was reported by two studies - both reported percentage reduction in area compared with baseline (Franek 2006; Taradaj 2007). Only one study reported a greater reduction in ulcer area with ultrasound than without (Franek 2006), however this study was at unclear risk of bias.

In terms of secondary outcomes, only one trial, Watson 2011, measured and reported health-related quality of life and found no association with treatment. The same trial found significantly more adverse events in the ultrasound arm than in the standard care arm, though most of these were non-serious. It also reported the outcome of cost, and showed no significant difference between the two arms.

In summary, it is unclear whether therapeutic ultrasound increases the healing of venous leg ulcers and any effect is likely to be very small.

\section{Overall completeness and applicability of evidence}

There are significant weaknesses in the completeness and applicability of the evidence overall. The trials were clinically heterogeneous with differences in duration of follow-up (ranging from three weeks, through four weeks, seven weeks, eight weeks, and 12 weeks to 12 months). Four of the 11 studies were conducted by a single research team in Poland (Franek 2004; Franek 2006; Taradaj 2007; Taradaj 2008), and two of these studies were not included in meta-analysis due to the lack of complete healing data in the original published trial reports.

Only one study reported costs, adverse events and quality of life via reliable methodologies (Watson 2011). Clearly any impact of treatments on patients' quality of life is invaluable information for all decision makers - particularly patients. The relative costeffectiveness of ultrasound treatment is essential information for healthcare founders and providers. We therefore urge that future research in this field uses reliable methodologies to measure these outcomes.

There is relatively little replication of studies, with single, small studies for most comparisons. This weak evidence base makes it impossible to draw conclusions with confidence.

\section{Quality of the evidence}

\section{Limitations of design and implementation}

RCTs need to be adequately powered so that they are able to detect treatment effects of a specified size, should they exist. This means that sample size calculations should be used to help estimate the number of people who should be recruited to a trial. Additionally trials should have an adequate follow-up period to ensure enough time for important outcome events, such as complete wound healing, to occur. The trials included in this study were all small and their follow-up periods were generally short. This resulted in an evidence base with almost no complete healing data; generally the relevant outcome data that were reported were underpowered and imprecise, with wide confidence intervals.

Most studies included in this review were at a high or unclear risk of bias. In general, studies did not follow good practice for conduct and reporting guidelines, for example CONSORT (Schulz 2010). Key areas of good practice are the robust generation of a randomisation sequence, for example one that is computergenerated; robust allocation concealment, for example by use of a telephone randomisation service; and blinded outcome assessment where possible. All this information should be clearly stated in the study report, as all trial authors should anticipate the inclusion of their trials in systematic reviews. Additionally, studies should report clearly how they planned to collect adverse event data and how this process was standardised for both treatment arms. In terms of analysis, where possible, data from all participants should be included, that is, an intention-to-treat analysis should be conducted and measurements of variation such as the standard deviation or standard error should be presented around outcome measurements where appropriate. As far as is possible when conducting trials, steps should be taken to prevent missing data.

Where possible, studies should use validated scales to measure outcomes. The use of invalidated scales, including those that have been modified in an ad hoc way, can limit the value of the data collected, as it can be difficult to interpret and to synthesis across studies.

\section{Potential biases in the review process}

The review considered as much evidence as it was possible to obtain, including studies that were not published in English language journals. While there is a potential for publication bias, this is unlikely to be a problem for this review given the large number of negative findings that have been published.

\section{Agreements and disagreements with other studies or reviews}

Current evidence does not indicate a difference in the healing of venous leg ulcers when using or not using ultrasound. This finding is consistent with that of another systematic review of ultrasound on pressure ulcers (Akbari Sari 2006), which also found uncertain evidence of benefit of ultrasound therapy.

\section{AUTHORS' CONCLUSIONS}

\section{Implications for practice}

There is no clear evidence that therapeutic ultrasound increases the healing of venous leg ulcers and the existing evidence is of very 
low to moderate quality. This information needs to be interpreted with care, as only one study measured wound healing at 12 months, most studies had very short durations of follow-up. Furthermore, reporting of adverse events was poor across most included studies and only one study measured adverse events using accepted approaches.

\section{Implications for research}

We identified only one high quality randomised controlled trial (RCT) of therapeutic ultrasound for venous leg ulcers (Watson 2011), and few studies that measured the secondary outcomes of adverse events, pain, quality of life and cost. Any future trials of therapeutic ultrasound should measure and report these outcomes carefully alongside healing data.

Most of the RCTs included in this review had methodological and reporting problems. Future RCTs that evaluate ultrasound treatment should employ robust randomisation methods and concealment of allocation procedures to minimise bias. In addition, blinded outcome assessment and the intention-to-treat principle should be adopted, again, in order to minimise bias. Where participants have been lost to follow-up, appropriate and valid methods of imputation should be used and reported. These methodological aspects should be reported clearly, in line with the CONSORT (Consolidated Standards of Reporting Trials) guidelines (Schulz 2010). Length of time to healing should be measured and reported using appropriate survival analysis with adjustment for prognostic covariates such as ulcer area and duration. Future RCTs should be adequately powered in order to detect important treatment effects and sample size estimates should be transparent. Those planning future RCTs should consider the extent to which the recruited population is likely to represent patients seen in clinical practice, particularly with respect to mobility, ulcer size and duration, and the presence of ulcer infection.

Future research should carefully investigate the safety and adverse events associated with ultrasound use. Health-related quality of life assessment should be undertaken using a valid and reliable assessment instrument, with findings reported in full. As the ultrasound treatment for the management of venous leg ulcers may be guided by cost, those planning future RCTs should consider incorporation of meaningful cost-effectiveness information.

All trials should be registered with a trials register that meets the World Health Organization (WHO) criteria, and principal investigators should keep their contact details up to date on the register.

\section{A C K N OWLE D GEMENTS}

The review authors are grateful to the following peer reviewers for their time and comments: Andrew Jull, Pamela Houghton, Andrea Nelson, Gill Worthy and Anne-Marie Glenny. The review authors would like to acknowledge the contribution of copyeditor Elizabeth Royle. Kate Flemming was a co-author of the original review and Sally Bell-Syer and Deyaa Al-Khurdi were coauthors of previous updates, we acknowledge their contributions. The authors are also grateful to Pawel Kanturski for his Polish translation services. 


\section{R E F E R E N C E S}

\section{References to studies included in this review}

Callam 1987 \{published data only\}

Callam MJ. Trial of ultrasound in the treatment of chronic leg ulceration. 5th Annual Symposium on Advanced Wound Care; 1992 April 23-25; New Orleans, (LA). 1992:124.

Callam MJ, Dale JJ, Ruckley CV, Harper DR. Trial of ultrasound in the treatment of chronic leg ulceration. In: Negus D, Jantet G editor(s). Phlebology. Eastleigh (Australia): John Libbey Co Ltd, 1986:625-6.

* Callam MJ, Harper DR, Dale JJ, Ruckley CV, Prescott RJ. A controlled trial of weekly ultrasound therapy in chronic leg ulceration. Lancet 1987;8552:204-6.

\section{Dolibog 2008 \{published data only\}}

Dolibog P, Franek A, Tardaj J, Blaszczak E, Cierpka L. Efficiency of therapeutic ultrasound for healing venous leg ulcers in surgical treated patients. Wounds 2008;20(12):334-40.

\section{Eriksson 1991 \{published data only\}}

Eriksson SV, Lundeberg T, Malm M. A placebo controlled trial of ultrasound therapy in chronic leg ulceration. Scandinavian Journal of Rehabilitation Medicine 1991;23:211-3.

\section{Franek 2004 \{published data only\}}

Franek A, Chmielewska D, Brzezinska-Wcislo L, Slezak A, Blaszczak E. Application of various power densities of ultrasound in the treatment of leg ulcers. Journal of Dermatological Treatment 2004;15(6):379-86.

\section{Franek 2006 \{published data only\}}

Blaszczak E, Franek A, Taradaj J, Dolibog P. Evaluation of healing process dynamics of the leg venous ulcers treated by means of selected physical methods. Fizjoterapia 2007;15(1):3-16.

Franek A, Krol P, Chmielewska D, Blaszczak E, Polak A, Kucharzewski M, et al. The venous ulcer therapy in use of the selected physical methods (Part 2) The comparison analysis. Polski Merkuriusz Lekraski 2006;20(120):691-5.

\section{Lundeberg 1990 \{published data only\}}

Lundeberg T, Nordstrom F, Brodda-Jansen G, Eriksson SV, Kjartansson J, Samuelson UE. Pulsed ultrasound does not improve healing of venous ulcers. Scandinavian Journal of Rehabilitation Medicine 1990;22:195-7.

Peschen 1997 \{published data only\}

Peschen M, Vanscheidt W. Low frequency ultrasound of chronic venous leg ulcers as part of an out-patient treatment. Proceedings of the 5th European Conference on Advances in Wound Management; 1995 November 21-24, Harrogate (UK). 1996:271.

* Peschen M, Weichenthal M, Schopf E, Vanscheidt W. Lowfrequency ultrasound treatment of chronic venous leg ulcers in an outpatient therapy. Acta Dermato-venereologica 1997;77(4):311-4.
Taradaj 2007 \{published data only\}

Taradaj J, Franek A, Dolibog P, Cierpka L, Blaszczak E. The impact of the sonotherapy and compression therapy on enhancement of healing venous leg ulcers after surgical treatment. Polski Merkuriusz Lekraski 2007;23(138):426-9.

Taradaj 2008 \{published data only\}

Taradaj J, Franek A, Brzezinska-Wcislo L, Cierpka L, Dolibog P, Chmielewska $D$, et al. The use of therapeutic ultrasound in venous leg ulcers: a randomized, controlled clinical trial. Phlebology 2008;23(4):178-83.

\section{Watson 2011 \{published data only\}}

Watson JM, Kang'ombe AR, Soares MO, Chuang L-H, Worthy G, Bland JM, et al. on behalf of the VenUS III team. VenUS III: a randomised controlled trial of therapeutic ultrasound in the management of venous leg ulcers. Health Technology Assessment 2011;15(13):1-192.

\section{Weichenthal 1997 \{published data only\}}

Mohr P, Weichenthal M, Stegmann W, Brietbart EW. Ultrasound treatment of chronic leg ulcers. 1st Joint Meeting of the Wound Healing Society and the European Tissue Repair Society; 1993 August 22-25; Amsterdam (The Netherlands). 1993:89.

Weichenthal M. $30 \mathrm{kHz}$ ultrasound treatment of chronic leg ulcer. 4th Annual Meeting of the European Tissue Repair Society; 1994 August 25-28; Oxford (UK). 1994:203.

* Weichenthal M, Mohr P, Stegmann W, Brietbart EW. Lowfrequency ultrasound treatment of chronic venous ulcers. Wound Repair and Regeneration 1997;5(1):18-22.

\section{References to studies excluded from this review}

Dissemond 2003 \{published data only\}

Dissemond J, Fitz G, Goos M. Wound bed preparation of chronic wounds with ultrasound. Hautarzt 2003;54(6):524-9.

Dyson 1976 \{published data only\}

Dyson M, Franks C, Suckling J. Stimulation of healing of varicose ulcers by ultrasound. Ultrasonics 1976;14:232-6.

Kavros 2007a \{published data only\} Kavros SJ, Miller JL, Hanna SW. Treatment of ischemic wounds with noncontact, low-frequency ultrasound: the Mayo clinic experience, 2004-2006. Advances in Skin and Wound Care 2007;40(4):221-6

\section{Kavros 2007b \{published data only\}}

Kavros SJ, Schenck EC. Use of noncontact low-frequency ultrasound in the treatment of chronic foot and leg ulcerations: a 51-patient analysis. Journal of the American Podiatric Medical Association 2007;97(2):95-101.

Roche 1984 \{published data only\}

Roche C, West J. A controlled trial investigating the effect of ultrasound on venous ulcers referred from general practitioners. Physiotherapy 1984;70(12):475-7. 
Tan 2007 \{published data only\}

Tan J, Abisi S, Smith A, Burnand KG. A painless method of ultrasonically assisted debridement of chronic leg ulcers: a pilot study. European Journal of Vascular and Endovascular Surgery 2007;33(2):234-8.

\section{References to studies awaiting assessment}

White 2016 \{published data only\}

White J, Ivins N, Wilkes A, Carolan-Rees G, Harding KG. Noncontact low-frequency ultrasound therapy compared with UK standard of care for venous leg ulcers: a single-centre, assessorblinded, randomised controlled trial. International Wound Journal 2016;13(5):833-42.

\section{Additional references}

\section{Akbari Sari 2006}

Akbari Sari A, Flemming K, Cullum NA, Wollina U. Therapeutic ultrasound for pressure ulcers. Cochrane Database of Systematic Reviews 2006, Issue 3. [DOI: 10.1002/14651858.CD001275.pub2]

\section{Ashby 2014}

Ashby RL, Gabe R, Ali S, Adderly U. Clinical and cost effectiveness of compression hosiery versus compression bandages in treatment of venous leg ulcers (Venous leg Ulcer Study IV, VenUS IV): a randomised controlled trial. Lancet 2014;383:871-9.

\section{Baker 2001}

Baker KG, Robertson VJ, Duck FA. A review of therapeutic ultrasound: biophysical effects. Physical Therapy 2001;81(7):1351-8

\section{Barwell 2004}

Barwell JR, Davies CE, Deacon J, Harvey K, Minor J, Sassano A, et al. Comparison of surgery and compression with compression alone in chronic venous ulceration (ESCHAR study): randomised controlled trial. Lancet 2004;363(9424):1854-9.

\section{British Association of Dermatologists 2010}

British Association of Dermatologists. Venous leg ulcers: patient information leaflet. www.bad.org.uk/for-the-public/patientinformation-leaflets/venous-leg-ulcers (accessed 26 October 2016).

\section{Busse 2009}

Busse JS, Kaur J, Mollon B, Bhandari M, Tornetta P, Schünemann $\mathrm{HJ}$, et al. Low intensity pulsed ultrasonography for fractures: systematic review of randomised controlled trials. BMJ 2009;338:b351.

\section{Byl 1992}

Byl NN, McKenzie AL, West JM, Whitney JD, Hunt TK, Scheuenstuhl HA. Low-dose ultrasound effects on wound healing: a controlled study with utacan pigs. Archives of Physical Medicine and Rehabilitation 1992;73:656-64.

\section{Callam 1985}

Callam MJ, Ruckley CV, Harper DR, Dale JJ. Chronic ulceration of the leg: extent of the problem and provision of care. British Medical Journal 1985;290:1855-6.

\section{Carradice 2011}

Carradice D, Mazari FA, Samuel N, Allgar V, Hatfield J, Chetter IC. Modelling the effect of venous disease on quality of life. British Journal of Surgery 2011;98(8):1089-98.

\section{Carstensen 2000}

Carstensen EL, Gracewski S, Dalecki D. The search for cavitation in vivo. Ultrasound in Medicine and Biology 2000;26(9):1377-85.

\section{Casimiro 2002}

Casimiro L, Brosseau L, Robinson V, Milne S, Judd M, Wells G, et al. Therapeutic ultrasound for the treatment of rheumatoid arthritis. Cochrane Database of Systematic Reviews 2002, Issue 3. [DOI: 10.1002/14651858.CD003787]

\section{Crum 1992}

Crum LA, Roy RA, Dinno MA, Church CC, Apfel RE, Holland CK, et al. Acoustic cavitation produced by microsecond pulses of ultrasound: a discussion of some selected results. Journal of the Acoustical Society of America 1992;91(2):1113-9.

\section{Deeks 2011}

Deeks JJ, Higgins JP, Altman DG. Chapter 9: Analysing data and undertaking meta-analyses. In: Higgins JP, Green S, editor(s). Cochrane Handbook for Systematic Reviews of Interventions Version 5.1.0 (updated March 2011). The Cochrane Collaboration, 2011. Available from handbook.cochrane.org. The Cochrane Collaboration, 2011. Available from www.cochrane-handbook.org.

\section{Doan 1999}

Doan N, Reher P, Meghji S. In vitro effects of therapeutic ultrasound on cell proliferation, protein synthesis, and cytokine production by human fibroblasts, osteoblasts, and monocytes. Journal of Oral and Maxillofacial Surgery 1999;57:409-19.

\section{Donnelly 2009}

Donnelly R, London N. In: Hoboken, NJ editor(s). ABC of arterial and venous disease. 2nd Edition. Chichester, UK: Wiley Blackwell/BMJ, 2009.

\section{Dyson 1987}

Dyson M. Mechanisms involved in therapeutic ultrasound. Physiotherapy 1987;73(3):116-20.

\section{Francis 1992}

Francis CW, Onundarson PT, Carstensen EL, Blinc A, Meltzer RS, Schwarz K, et al. Enhancement of fibrinolysis in vitro by ultrasound. Journal of Clinical Investigation 1992;90(5):2063-8.

\section{GRADEpro GDT 2015 [Computer program]}

McMaster University (developed by Evidence Prime, Inc.). GRADEpro Guideline Development Tool. Version updated December 2015. McMaster University (developed by Evidence Prime, Inc.), 2015. 


\section{Graham 2003}

Graham ID, Harrison MB, Shafey M, Keast D. Knowledge and attitudes regarding care of leg ulcers: survey of family physicians. Canadian Family Physician 2003;49:896-902.

\section{Guyatt 2011}

Guyatt GH, Oxman AD, Kunz R. GRADE Guidelines 6. Rating the quality of evidence: imprecision. Journal of Clinical Epidemiology 2011;64:1283-93.

\section{Hall 2014}

Hall J, Buckley HL, Lamb KA, Stubbs N, Saramago P, Dumville JC, et al. Point prevalence of complex wounds in a defined United Kingdom population. Wound Repair and Regeneration 2014;22(6):694-700.

\section{Hansen 1973}

Hansen TI, Kristensen JH. Effect of massage, shortwave diathermy and ultrasound upon 133 Xe disappearance rate from muscle and subcutaneous tissue in the human calf. Scandinavian Journal of Rehabilitaion Medicine 1973;5:179-82.

\section{Hart 1998}

Hart J. The use of ultrasound therapy in wound healing. Journal of Wound Care 1998;7(1):25-8.

\section{Hay-Smith 1998}

Hay-Smith EJ. Therapeutic ultrasound for postpartum perineal pain and dyspareunia. Cochrane Database of Systematic Reviews 1998, Issue 3. [DOI: 10.1002/14651858.CD000495]

\section{Higgins 2003}

Higgins JP, Thompson SG, Deeks JJ, Altman DG. Measuring inconsistency in meta-analyses. BMJ 2003;327:557-60.

\section{Higgins 2011}

Higgins JP, Green S, editor(s). Cochrane Handbook for Systematic Reviews of Interventions Version 5.1.0 (updated March 2011). The Cochrane Collaboration, 2011. Available from handbook.cochrane.org. The Cochrane Collaboration, available from www.cochrane-handbook.org.

\section{Hoffrage 2000}

Hoffrage U, Lindsey S, Hertwig R, Gigerenzer G. Medicine: communicating statistical information. Science 2000;290(5500):2261-2.

\section{Hogan 1982}

Hogan RD, Franklin TD, Fry FJ. The effect of ultrasound on microvascular hemodynamics in skeletal muscle: effect on arterioles. Ultrasound in Medicine and Biology 1982;8(1):45-55.

\section{Iglesias 2004}

Iglesias C, Nelson EA, Cullum NA, Torgerson DJ and the VenUS I team. VenUS I: a randomised controlled trial of two types of bandage for treating venous leg ulcers. Health Technology Assessment 2004;8:1-105.

\section{Ito 2000}

Ito M, Azuma Y, Ohta T, Komoriya K. Effects of ultrasound and 1,25-dihydroxyvitamin D3 on growth factor secretion in co- cultures of osteoblasts and endothelial cells. Ultrasound in Medicine and Biology 2000;26(1):161-6.

\section{Johns 2002}

Johns LD. Nonthermal effects of therapeutic ultrasound: the frequency resonance hypothesis. Journal of Athletic Training 2002;37(3):293-9.

\section{Lafuma 1994}

Lafuma A, Fangani F, Peltier-Pujol F, Rauss A. Venous disease in France: an unrecognized health problem [La maladie veineuse en France: un problème de santé publique méconnu]. Journal des Maladies Vasculaires 1994;19:185-9.

\section{Lefebvre 2011}

Lefebvre C, Manheimer E, Glanville J, on behalf of the Cochrane Information Retrieval Methods Group. Chapter 6: Searching for studies. In: Cochrane Handbook for Systematic Reviews of Interventions Version 5.1.0 (updated March 2011). The Cochrane Collaboration, 2011. Available from handbook.cochrane.org.

\section{Liberati 2009}

Liberati A, Altman DG, Tetzlaff J, Mulrow C, Gotzsche PC, loannidis JP, et al. The PRISMA statement for reporting systematic reviews and meta-analyses of studies that evaluate health care interventions: explanation and elaboration. PLOS Medicine 2009;6(7):e1000100.

\section{Margolis 2002}

Margolis DJ, Bilker W, Santanna J, Baumgarten M. Venous leg ulcer: incidence and prevalence in the elderly. Journal of the American Academy of Dermatology 2002;46(3):381-6.

\section{Maxwell 1994}

Maxwell L, Collecutt T, Gledhill M, Sharma S, Edgar S, Gavin JB. The augmentation of leucocyte adhesion to endothelium by therapeutic ultrasound. Ultrasound in Medicine and Biology 1994;20(4):383-90.

\section{McCulloch 2010}

McCulloch JM, Kloth L. Wound Healing: Evidence-Based Management. 4th Edition. Philadelphia (PA): Davis Company, 2010.

\section{Michaels 2009}

Michaels JA, Campbell WB, King BM, Macintyre J, Palfreyman SJ, Shackley $\mathrm{P}$, et al. A prospective randomised controlled trial and economic modelling of antimicrobial silver dressings versus non-adherent control dressings for venous leg ulcers: the VULCAN trial. Health Technology Assessment 2009;13(56):1-114.

\section{Nelzen 1994}

Nelzen O, Bergqvist D, Lindhagen A. Venous and non-venous leg ulcers: clinical history and appearance in a population study. British Journal of Surgery 1994;81(2):182-7.

\section{Olin 1999}

Olin JW, Beuerstein KM, Childs MB, Seavey C, McHugh L, Griffiths RI. Medical costs of treating venous status ulcers: evidence from a retrospective cohort study. Vascular Medicine 1999;4(1):1-7. 


\section{Olsson 1994}

Olsson SB, Johansson B, Nilsson AM, Olsson C, Roijer A. Enhancement of thrombolysis by ultrasound. Ultrasound in Medicine and Biology 1994;20:375-82.

\section{Parmar 1998}

Parmar MK, Torri V, Stewert L. Extracting summary statistics to perform meta-analysis of the published literature for survival endpoints. Statistics in Medicine 1998;17:2815-34.

\section{Paul 1955}

Paul WD, Imig CJ. Temperature and blood flow studies after ultrasound irradiation. American Journal of Physical Medicine 1955;34:370-5.

\section{Posnett 2008}

Posnett J, Franks PJ. The burden of chronic wounds in the UK. Nursing Times 2008;104(3):44-5.

\section{RevMan 2014 [Computer program]}

Nordic Cochrane Centre, The Cochrane Collaboration. Review Manager 5 (RevMan 5). Version 5.3. Copenhagen: Nordic Cochrane Centre, The Cochrane Collaboration, 2014.

\section{Robinson 2001}

Robinson VA, Brosseau L, Peterson J, Shea BJ, Tugwell P, Wells $\mathrm{G}$. Therapeutic ultrasound for osteoarthritis of the knee. Cochrane Database of Systematic Reviews 2001, Issue 3. [DOI: 10.1002/14651858.CD003132]

\section{Ross 1983}

Ross P, Edmonds PD. Ultrasound induced protein synthesis as a result of membrane damage. Journal of Ultrasound in Medicine 1983;2:47.

\section{Ruckley 1997}

Ruckley CV. Socioeconomic impact of chronic venous insufficiency and leg ulcers. Angiology 1997;48(1):67-9.

\section{Schabrun 2006}

Schabrun S, Chipchase L, Rickard H. Are therapeutic ultrasound units a potential vector for nosocomial infection?. Physiotherapy Research International 2006;11(2):61-71.

\section{SIGN 2010}

SIGN. Management of chronic venous leg ulcers. Clinical guideline no 120. August 2010. www.sign.ac.uk/guidelines/ fulltext/120/ (accessed 26 October 2016).

\section{SIGN 2015}

Scottish Intercollegiate Guidelines Network (SIGN). Search filters. www.sign.ac.uk/methodology/filters.html\#random (accessed 26 October 2016).

\section{Ter Haar 1981}

Ter Haar GR, Daniels S. Evidence for ultrasonically induced cavitation in-vivo. Physics in Medicine and Biology 1981;26:1145-9.

\section{Ter Haar 1999}

Ter Haar G. Therapeutic ultrasound. European Journal of Ultrasound 199;9(1):3-9.

\section{Valencia 2001}

Valencia IC, Falabella A, Kirsner RS, Eaglstein WH. Chronic venous insufficiency and venous leg ulceration. Journal of the American Academy of Dermatology 2001;44(3):401-24.

\section{Van der Windt 2002}

Van der Windt DA, Van der Heijden GJ, Van den Berg SG, Ter Riet G, De Winter AF, Bouter LM. Therapeutic ultrasound for acute ankle sprains. Cochrane Database of Systematic Reviews 2002, Issue 1. [DOI: 10.1002/14651858.CD001250]

\section{Webster 1978}

Webster DF, Pond JB, Dyson M, Harvey W. The role of cavitation in the in vitro stimulation of protein synthesis in human fibroblasts by ultrasound. Ultrasound in Medicine and Biology 1978;4(4):343-51.

\section{Young 1990a}

Young SR, Dyson M. Macrophage responsiveness to therapeutic ultrasound. Ultrasound in Medicine and Biology 1990;16(8):809-16.

\section{Young 1990b}

Young SR, Dyson M. The effect of therapeutic ultrasound on angiogenesis. Ultrasound in Medicine and Biology 1990;16(3):261-9.

\section{References to other published versions of this review}

\section{Al-Kurdi 2008}

Al-Kurdi D, Bell-Syer SE, Flemming K. Therapeutic ultrasound for venous leg ulcers. Cochrane Database of Systematic Reviews 2008, Issue 1. [DOI: 10.1002/14651858.CD001180.pub2]

\section{Cullum 2010}

Cullum N, Al-Kurdi D, Bell-Syer SE. Therapeutic ultrasound for venous leg ulcers. Cochrane Database of Systematic Reviews 2010, Issue 6. [DOI: 10.1002/14651858.CD001180.pub3]

\section{Flemming 2000}

Flemming K, Cullum N. Therapeutic ultrasound for venous leg ulcers. Cochrane Database of Systematic Reviews 2000, Issue 4. [DOI: 10.1002/14651858.CD001180]

\footnotetext{
* Indicates the major publication for the study
}

\section{CHARACTERISTICS OF STUDIES}

Characteristics of included studies [ordered by study ID] 
Callam 1987

\begin{tabular}{ll}
\hline Methods & Randomised controlled trial in Scotland, UK \\
\hline Participants & 108 people with chronic leg ulcers attending participating physiotherapy clinics \\
& $\begin{array}{l}\text { Exclusion criteria: allergy to standard treatments, peripheral vascular disease } \\
\text { US group: } n=52 ; \\
\text { Standard treatment group: } 56\end{array}$ \\
\hline Interventions & $\begin{array}{l}\text { US group: once weekly pulsed, direct US } 0.5 \mathrm{~W} / \mathrm{cm}^{2} \text { at a frequency of } 1 \text { MHz, applied directly to the tis- } \\
\text { ment (see below) } \\
\text { Standard treatment group: standard regimen of } 1 \% \text { cetrimide in normal saline, followed by } \text { Arachis oil } \\
\text { to the skin (no massage), a paste bandage (Calaband), a Lestreflex support bandage and an exercise in- } \\
\text { struction sheet }\end{array}$
\end{tabular}

Outcomes Tracings of ulcer at $0,4,8,12$ weeks. Analysed using computerised planimetry.

Number of ulcers completely healed at 12 weeks (losses considered as treatment failures)

Mean percentage of initial ulcer area remaining at 12 weeks

Withdrawals by treatment group with reasons

Notes

Withdrawn participants were censored at the point of withdrawal except for those who withdrew due to deterioration, who were regarded as unhealed at 12 weeks.

NB the original Lancet paper report of this trial stated that the ultrasound frequency was $1 \mathrm{mHz}$. We contacted Mr Callam, the Principal Investigator, in November 2009. He confirmed that the frequency was $1 \mathrm{MHz}$ (bringing the trial into line with most of the others).

Duration of follow-up: 12 weeks

\section{Risk of bias}

\begin{tabular}{lll}
\hline Bias & Authors' judgement & Support for judgement \\
\hline $\begin{array}{l}\text { Random sequence genera- } \\
\text { tion (selection bias) }\end{array}$ & Low risk & $\begin{array}{l}\text { Quote: "Patients were randomised into a control group ... and a treatment } \\
\text { group" }\end{array}$ \\
\hline $\begin{array}{l}\text { Allocation concealment } \\
\text { (selection bias) }\end{array}$ & Low risk & $\begin{array}{l}\text { Quote: "Randomisation was made through a central office and was based on } \\
\text { the use of randomised permuted blocks, with stratification to ensure that ap- } \\
\text { propriate balance between the treatment groups was maintained at each cen- } \\
\text { tre" }\end{array}$
\end{tabular}

Blinding of participants High risk Participants and personnel not blinded
and personnel (perfor-
mance bias)
All outcomes

\begin{tabular}{|c|c|c|}
\hline $\begin{array}{l}\text { Blinding of outcome as- } \\
\text { sessment (detection bias) } \\
\text { All outcomes }\end{array}$ & Unclear risk & $\begin{array}{l}\text { Outcome assessors: tracings of the ulcer circumference were completed by } \\
\text { people who were not blind to treatment group, however, analysis of the trac- } \\
\text { ings (calculation of percentage area ulcer remaining) was blinded to treatment } \\
\text { group. }\end{array}$ \\
\hline
\end{tabular}

Quote: "The tracings were identified only by a code number to exclude observer bias"

\begin{tabular}{|c|c|c|}
\hline $\begin{array}{l}\text { Incomplete outcome data } \\
\text { (attrition bias) } \\
\text { Ulcer healing }\end{array}$ & Low risk & $\begin{array}{l}\text { Similar numbers withdrew from treatment groups for similar reasons; } 21 \% \\
\text { (11/52) withdrawals in US group and } 27 \%(15 / 56) \text { withdrawals in control group } \\
\text { due to allergy, pain, withdrawal of consent, deterioration, arterial disease and } \\
\text { death. These data were considered in intention-to-treatment analysis by study } \\
\text { authors. }\end{array}$ \\
\hline
\end{tabular}


Callam 1987 (Continued)

Selective reporting (re- Unclear risk $\quad$ Expected outcomes reported, though we did not request a study protocol. porting bias)

Other bias Unclear risk No details provided.

Dolibog 2008

\begin{tabular}{ll}
\hline Methods & Randomised controlled trial in Poland. \\
\hline Participants & \begin{tabular}{l}
70 participants post venous surgery, whose venous disease was diagnosed by Duplex scan (to rule out \\
arterial disease and locate the venous insufficiency) \\
Exclusion criteria: diabetes, and rheumatoid arthritis \\
US plus standard care group: $\mathrm{n}=33 ;$ \\
Standard care group: $\mathrm{n}=37$ \\
\hline US group: US via a water bath at $0.5 \mathrm{~W} / \mathrm{cm}^{2} ; 1$ MHz frequency, US probe $10 \mathrm{~cm}^{2}$ placed $2 \mathrm{~cm}$ above ul- \\
cer. An ulcer of $5 \mathrm{~cm} 2$ or less had 5 minutes treatment with 1 minute extra of treatment for every $1 \mathrm{~cm}{ }^{2}$ \\
by which the ulcer exceeded an area of $5 \mathrm{~cm}^{2}$. Treatment provided daily for 6 days/week for 7 weeks. \\
Between treatments ulcers were covered with saline-soaked gauze, received compression and $1 \mathrm{~g}$ \\
flavonoid fraction daily. US commenced 5 days after surgery. \\
Standard care group: saline soaks, compression, $1 \mathrm{~g}$ flavonoid fraction daily
\end{tabular} \\
\hline Proportion of ulcers completely healed \\
\hline Notes & $\begin{array}{l}\text { Ulcers were observed for complete healing and measured for area, volume and a range of dimensions } \\
\text { using planimetry. } \\
\text { Duration of follow-up: } 7 \text { weeks }\end{array}$ \\
\hline
\end{tabular}

\section{Risk of bias}

\begin{tabular}{lll}
\hline Bias & Authors' judgement & Support for judgement \\
\hline $\begin{array}{l}\text { Random sequence genera- } \\
\text { tion (selection bias) }\end{array}$ & Unclear risk & $\begin{array}{l}\text { Quote: "70 patients ... were included and allocated into two comparative } \\
\text { groups", "A prospective, randomised, controlled clinical trial was conducted" }\end{array}$ \\
\hline $\begin{array}{l}\text { Allocation concealment } \\
\text { (selection bias) }\end{array}$ & Unclear risk & Not mentioned, see above. \\
\hline $\begin{array}{l}\text { Blinding of participants } \\
\text { and personnel (perfor- } \\
\text { mance bias) } \\
\text { All outcomes }\end{array}$ & High risk & Participants: not blinded, since they did not receive sham US. \\
\hline $\begin{array}{l}\text { Blinding of outcome as- } \\
\text { sessment (detection bias) } \\
\text { All outcomes }\end{array}$ & Unclear risk & $\begin{array}{l}\text { Personnel: unclear, but presumably not blinded since study was not sham con- } \\
\text { trolled. }\end{array}$ \\
\hline $\begin{array}{l}\text { Incomplete outcome data } \\
\text { (attrition bias) } \\
\text { Ulcer healing }\end{array}$ & Unclear risk & $\begin{array}{l}\text { Outcome assessors: unclear } \\
\text { Quote: "Treatment progress was evaluated by observing the number of com- } \\
\text { pletely healed ulcers, and measuring the area ... by planimetry" }\end{array}$ \\
\hline
\end{tabular}


Dolibog 2008 (Continued)

Selective reporting (re- Unclear risk No details provided. porting bias)

Other bias Unclear risk No details provided.

\section{Eriksson 1991}

\begin{tabular}{|c|c|}
\hline Methods & Randomised trial comparing US plus standard care with sham US plus standard care in Sweden. \\
\hline \multirow[t]{4}{*}{ Participants } & $\begin{array}{l}\text { People with venous leg ulcers referred from departments of internal medicine and surgery, and prima- } \\
\text { ry care providers }\end{array}$ \\
\hline & $\begin{array}{l}\text { Exclusion criteria: allergy to the standard treatment, or evidence of peripheral arterial disease, rheuma- } \\
\text { toid arthritis, diabetic ulcers, or traumatic venous ulcers }\end{array}$ \\
\hline & US group: $\mathrm{n}=19$ \\
\hline & Sham US group: $\mathrm{n}=19$ \\
\hline Interventions & $\begin{array}{l}\text { US group: US } 1 \mathrm{~W} / \mathrm{cm}^{2} \text { at } 1 \mathrm{MHz} \text {, for } 10 \text { minutes twice a week for } 8 \text { weeks, plus standard treatment } \\
\text { Sham US group: standard treatment plus sham US as above, but with no output. Standard care com- } \\
\text { prised cleansing with saline; paste bandage, support bandage plus exercise advice. }\end{array}$ \\
\hline \multirow[t]{3}{*}{ Outcomes } & Number of ulcers known to be completely healed at 8 weeks (of those randomised) \\
\hline & Percentage ulcer area healed at 8 weeks (SD) \\
\hline & Withdrawals with reasons, and by group \\
\hline Notes & Duration of follow-up: 8 weeks \\
\hline
\end{tabular}

\section{Risk of bias}

\begin{tabular}{lll}
\hline Bias & Authors' judgement & Support for judgement \\
\hline $\begin{array}{l}\text { Random sequence genera- } \\
\text { tion (selection bias) }\end{array}$ & Unclear risk & $\begin{array}{l}\text { Quote: "patients were randomly assigned to either a control group ... or a } \\
\text { treatment group" }\end{array}$ \\
\hline $\begin{array}{l}\text { Allocation concealment } \\
\text { selection bias) }\end{array}$ & Unclear risk & See above. \\
\hline $\begin{array}{l}\text { Blinding of participants } \\
\text { and personnel (perfor- } \\
\text { mance bias) }\end{array}$ & Unclear risk & $\begin{array}{l}\text { Participants: this was a placebo (sham) US controlled trial, therefore, it was } \\
\text { implied that the participants did not know their allocation. }\end{array}$ \\
\hline $\begin{array}{l}\text { Blinding of outcome as- } \\
\text { sessment (detection bias) } \\
\text { All outcomes }\end{array}$ & Unclear risk & $\begin{array}{l}\text { Personnel: unclear (they may have been responsible for setting the ultrasound } \\
\text { machine to zero). }\end{array}$ \\
& $\begin{array}{l}\text { Outcome assessors: unclear whether those responsible for taking ulcer trac- } \\
\text { ings were blinded. Those responsible for analysing the tracings were blinded, } \\
\text { quote: "At the end of the } 8 \text { week study all tracings were analysed using a com- } \\
\text { puter graphics program to calculate the areas of each ulcer...The tracings were } \\
\text { identified by code numbers to exclude observer bias." }\end{array}$
\end{tabular}

Incomplete outcome data Unclear risk

(attrition bias)

Ulcer healing
38 people randomised; 13 withdrew. Not clear how these were handled.

Quote: "The cumulative percentage of healed ulcers in the two groups was compared by the use of life table methods" (censoring not mentioned), and. In 
Eriksson 1991 (Continued)

the Results section: "If analysed by intention to treat there were similar nonsignificant findings between the groups".

\begin{tabular}{lll}
\hline $\begin{array}{l}\text { Selective reporting (re- } \\
\text { porting bias) }\end{array}$ & Unclear risk & No details provided. \\
\hline Other bias & Unclear risk & No details provided. \\
\hline
\end{tabular}

\section{Franek 2004}

$\begin{array}{ll}\text { Methods } & \begin{array}{l}\text { Randomised trial comparing two US densities }\left(0.5 \mathrm{~W} / \mathrm{cm}^{2} \text { and } 1 \mathrm{~W} / \mathrm{cm}^{2}\right) \text { with no US and pharmacother- } \\ \text { apy }\end{array}\end{array}$

Participants
People were excluded if they had diabetes mellitus or advanced sclerosis.
US group $1\left(1 \mathrm{~W} / \mathrm{cm}^{2}\right): \mathrm{n}=22 ;$
US group $2\left(0.5 \mathrm{~W} / \mathrm{cm}^{2}\right): \mathrm{n}=21 ;$
Pharmacotherapy group: $\mathrm{n}=22$.
Mean (median) baseline area $\left(\mathrm{cm}^{2}\right):$
US group 1: $15.62(12.51) ;$
US group 2: $15.57(6.71) ;$
Pharmacotherapy group: $23.74(11.72)$.
The authors did not publish the SD or SE around the mean.

Interventions US group 1: pulsed $1 \mathrm{MHz}, 1 \mathrm{~W} / \mathrm{cm}^{2}$ in a water bath with a temperature of $34^{\circ} \mathrm{C}$ plus standard treatment of topical wet dressings of isotonic salt solution and compression therapy. Participants were admitted to the Dermatology Clinic of the Silesian Medical University in Katowice.

US group 2: pulsed $1 \mathrm{MHz}, 0.5 \mathrm{~W} / \mathrm{cm}^{2}$ in a water bath with a temperature of $34^{\circ} \mathrm{C}$ plus standard treatment of topical wet dressings of isotonic salt solution and compression therapy. Participants were admitted to the Dermatology Clinic of the Silesian Medical University in Katowice.

Pharmacotherapy group: topical pharmacotherapy including potassium permanganate local baths, wet dressing of $0.1 \mathrm{M}$ copper sulphate solution, compresses of fibrolan, chloramphenicol, colistin, gentamicin plus compressive therapy. Participants were hospitalised in the Dermatology Department of Hospital No. 2 in Zabrze.

These 3 treatment groups differed systematically not only in the US treatment but the pharmacotherapy received by the pharmacotherapy group and its place of treatment (different from that of the US groups).

\begin{tabular}{|c|c|}
\hline Outcomes & $\begin{array}{l}\text { Number of ulcers completely healed at } 3 \text { weeks } \\
\text { Average weekly rate of ulcer area reduction (\% per week) }\end{array}$ \\
\hline Notes & $\begin{array}{l}\text { No withdrawals reported. } \\
\text { "Planimetric measurements of homothetic, congruent projections of the ulcerated areas using a digi- } \\
\text { tising tablet. Ulcer depth measured ...with a precision built mechanical micrometer..." } \\
\text { Duration of follow-up: } 3 \text { weeks }\end{array}$ \\
\hline
\end{tabular}

\section{Risk of bias}

\begin{tabular}{lll}
\hline Bias & Authors' judgement & Support for judgement \\
\hline $\begin{array}{l}\text { Random sequence genera- } \\
\text { tion (selection bias) }\end{array}$ & Unclear risk & $\begin{array}{l}\text { Quote: "A total of } 65 \text { patients with venous ulcers were randomly divided into } \\
\text { three groups ...". }\end{array}$ \\
\hline
\end{tabular}


Franek 2004 (Continued)

\begin{tabular}{l}
$\begin{array}{l}\text { Allocation concealment } \\
\text { (selection bias) }\end{array}$ \\
\hline
\end{tabular}

Blinding of participants and personnel (performance bias)

All outcomes

\section{High risk}

Participants: no (no sham US).

Personnel: no, as the control patients were treated in a different hospital.

\section{Blinding of outcome as- High risk} sessment (detection bias) All outcomes Outcome assessors: no: "To check how the ulcers healed we measured the longest dimensions ... and the widest dimensions perpendicular to the former ... measurements were taken before the treatment, every week during treatment and upon completion ...".

\begin{tabular}{|c|c|c|}
\hline $\begin{array}{l}\text { Incomplete outcome data } \\
\text { (attrition bias) }\end{array}$ & Unclear risk & $\begin{array}{l}\text { Complete follow-up implied but not stated. No mention of intention-to-treat } \\
\text { analysis. }\end{array}$ \\
\hline
\end{tabular}

Ulcer healing analysis.

Selective reporting (re- Unclear risk No details provided.
porting bias)

Other bias High risk

Major performance bias. Control group patients (pharmacotherapy group) received topical ulcer treatments that were not received by the US patients, and they were admitted to a different hospital.

Franek 2006

Methods $\quad$ Randomised trial in different hospitals in Poland

Participants

92 people with venous leg ulcers presenting symptoms of chronic venous insufficiency, some had varicose veins and symptoms of postthrombotic syndrome. $\mathrm{ABPI}>0.8$

Exclusion criteria: presence of diabetes or atherosclerosis

Number of male: female participants: Electrostimulation group: 8:18; Laser therapy group: 4:17; US group: 4:11; Compression + pharmacological agents: 3:21

Mean (range) participant age in years: Electrostimulation group: 69.8 (48-90); Laser therapy group: 65.2 (44-80); US group: 63.6 (37-82); Compression + pharmacological agents: 67 (43-86)

Mean (range) initial ulcer area in $\mathrm{cm}^{2}$ : Electrostimulation group: 17.6 (2.6-65.8); Laser therapy group: 15.8 (0.5-59.6); US group: 15.6 (0.4-84.7); Compression + pharmacological agents: 17.3 (1.9-84)

Mean (range) ulcer duration in months/years: Electrostimulation group: 4.5 years (2 months-12 years); Laser therapy group: 3.5 years ( 2 months-24 years); US group: 1.7 years ( 3 months- 8 years); Compression + pharmacological agents: 2.7 years ( 3 months- 11 years)

All groups received compression therapy, bandages were removed for purposes of physical therapy and then put back on.

Electrostimulation group: 50-minute session once daily, for 6 consecutive days, for a total of 4 weeks total ( 2 weeks katodic and 2 weeks anodic stimulation), $\mathrm{NaCl} 0.9 \%$ locally (no further details provided)

Laser therapy group: $65 \mathrm{~mW}$ laser therapy session once daily, for 5 consecutive days, the duration of each session depended on the size of ulceration area - device was set up to develop $4 \mathrm{~J} / \mathrm{cm}^{2}$ on average power $65 \mathrm{~mW}$, various pharmacological agents applied locally, for a total of 4 weeks 
US group: $0.5 \mathrm{~W} / \mathrm{cm}^{2}$ once daily, duration of each session depended on the size of ulceration area: 5 minutes of therapy given for $5 \mathrm{~cm}^{2}$ ulcer, 1 additional minute of therapy given for each additional $1 \mathrm{~cm}^{2}$ of ulceration area, for a total of 4 weeks, $\mathrm{NaCl} 0.9 \%$ locally

Compression (no further details provided) plus pharmacological agents: compression and local application of collistin (no further details provided), chloramphenicol, gentamycin, fibrolan, potassium permanganate, copper sulphate, according to medical indications, no phlebotropic drugs), for a total of 4 weeks

\begin{tabular}{ll}
\hline Outcomes & Changes in the area, length, width and volume of the tissue defect after above physical therapies \\
\hline Notes & No withdrawals reported. \\
& Duration of follow-up: 4 weeks \\
\hline
\end{tabular}

\section{Risk of bias}

\section{Bias Authors' judgement Support for judgement}

Random sequence genera- Unclear risk
tion (selection bias)

From translator: "... random assignment ... "

Comment: no randomisation method specified. Authors did not state whether participants were randomized before or after surgery.

Allocation concealment Unclear risk No details provided.

(selection bias)

Blinding of participants Unclear risk No details provided.

and personnel (perfor-

mance bias)

All outcomes

\begin{tabular}{lll}
\hline $\begin{array}{l}\text { Blinding of outcome as- } \\
\text { sessment (detection bias) } \\
\text { All outcomes }\end{array}$ & Unclear risk & No details provided. \\
\hline $\begin{array}{l}\text { Incomplete outcome data } \\
\begin{array}{l}\text { (attrition bias) } \\
\text { Ulcer healing }\end{array}\end{array}$ & Unclear risk & $\begin{array}{l}\text { No report of withdrawals, and not clear from report whether all participants } \\
\text { were included in the analyses. }\end{array}$ \\
\hline $\begin{array}{l}\text { Selective reporting (re- } \\
\text { porting bias) }\end{array}$ & Unclear risk & No details provided. \\
\hline Other bias & Unclear risk & No details provided. \\
\hline
\end{tabular}

Lundeberg 1990

\begin{tabular}{ll}
\hline Methods & Randomised controlled trial of high-frequency US compared with sham US \\
\hline Participants & 44 people with venous leg ulcers referred from departments of internal medicine, surgery, and primary \\
care & \\
& Exclusion criteria: peripheral vascular disease, rheumatoid arthritis, diabetes mellitus, or traumatic ve- \\
& nous ulcer \\
& US group: $\mathrm{n}=22 ;$ \\
& Sham US group: $\mathrm{n}=22$
\end{tabular}


Lundeberg 1990 (Continued)

Interventions
US group: US $0.5 \mathrm{~W} / \mathrm{cm}^{2}$, at $1 \mathrm{MHz}$ for 10 minutes. US was directly applied to the ulcer and surrounding tissue. Treatment frequency: 3 times a week for 4 weeks, twice a week for 4 weeks, and once weekly for 4 weeks, unless healing had occurred. Participants also received standard treatment (see below). Sham US group: sham US plus standard treatment of ulcer, i.e. cleansed with saline, application of paste bandage, support bandage and advice on exercise from a standard instruction sheet.

\begin{tabular}{ll}
\hline Outcomes & Number of ulcers completely healed at 12 weeks \\
Mean percentage of initial ulcer area remaining at 12 weeks \\
Withdrawals by group, with reasons
\end{tabular}

Notes Duration of follow-up: 12 weeks

\section{Risk of bias}

\begin{tabular}{|c|c|c|}
\hline Bias & Authors' judgement & Support for judgement \\
\hline $\begin{array}{l}\text { Random sequence genera- } \\
\text { tion (selection bias) }\end{array}$ & Low risk & $\begin{array}{l}\text { Quote: "The patients were randomly assigned ...The distribution of the pa- } \\
\text { tients was based on the use of randomised permuted blocks" }\end{array}$ \\
\hline $\begin{array}{l}\text { Allocation concealment } \\
\text { (selection bias) }\end{array}$ & Unclear risk & Not mentioned. \\
\hline $\begin{array}{l}\text { Blinding of participants } \\
\text { and personnel (perfor- } \\
\text { mance bias) } \\
\text { All outcomes }\end{array}$ & Unclear risk & $\begin{array}{l}\text { Participants: blinded (sham compared with active). } \\
\text { Personnel: unclear whether they were blinded, as they might have been re- } \\
\text { sponsible for setting the ultrasound machine to zero. }\end{array}$ \\
\hline $\begin{array}{l}\text { Blinding of outcome as- } \\
\text { sessment (detection bias) } \\
\text { All outcomes }\end{array}$ & Unclear risk & $\begin{array}{l}\text { Outcome assessors: unclear whether person taking the ulcer tracing was } \\
\text { aware of allocation. Person analysing the tracing was blinded, quote: "At the } \\
\text { end of the } 12 \text { week study all tracings were analysed using a computer graphics } \\
\text { program to calculate the areas of each ulcer ... tracings were identified by code } \\
\text { numbers to exclude observer bias" }\end{array}$ \\
\hline
\end{tabular}

\section{Incomplete outcome data High risk} (attrition bias)

Ulcer healing

\begin{abstract}
44 participants were randomised; 12 withdrew (evenly distributed between groups and for similar reasons).

Quote: "Patients refused to continue or withdrew from the study for any of the following reasons: allergy to treatment; excessive pain; intervening illness ...". The analysis was by "life table methods" but it is not clear if withdrawn patients were censored. A quote from the Results: "The lack of difference was also maintained when taking withdrawals into consideration. If analysed by intention to treat there were similar non-significant findings ..." would suggest they were not.
\end{abstract}

\begin{tabular}{|c|c|}
\hline $\begin{array}{l}\text { Selective reporting (re- } \\
\text { porting bias) }\end{array}$ & No details provided. \\
\hline Other bias & No details provided. \\
\hline \multicolumn{2}{|l|}{ Peschen 1997} \\
\hline Methods & Randomised controlled trial in Germany. \\
\hline Participants & $\begin{array}{l}24 \text { people attending an outpatient clinic, with a venous leg ulcer of minimum area } 2 \mathrm{~cm}^{2} \text {, and minimum } \\
\text { duration of } 3 \text { months. Clinical diagnosis of venous disease confirmed by history, Doppler US, light re- } \\
\text { flection rheography, ABPI } \geq 0.8\end{array}$ \\
\hline
\end{tabular}


Peschen 1997 (Continued)

Exclusion criteria: arterial disease, liver disease, cardiac or renal insufficiency, haemorrhagic gastroduodenitis, colitis, leukaemia, diabetes, rheumatoid arthritis, treatment allergy

US group: $\mathrm{n}=12$;

Sham US group: $\mathrm{n}=12$

Mean ulcer area $\left(\mathrm{cm}^{2}\right)(\mathrm{SD})$ :

US group: 15.67 (19.91);

Sham US group: 19.94 (17.11)

Mean ulcer duration (SD) (months):

US group: 5.5 (3.2);

Sham US group: $4.5(1.1)$

Interventions

US group: US $30 \mathrm{kHz}$, at $0.1 \mathrm{~W} / \mathrm{cm}^{2}$ for 10 minutes 3 times a week plus standard therapy (comprised of hydrocolloid dressings and "strong" compression therapy). The US (indirect method) was delivered by placing legs in a footbath of $32^{\circ} \mathrm{C}-34^{\circ} \mathrm{C}$ water at filled to $10 \mathrm{~cm}$ above the ulcer. The US probe was immersed in the bath $5 \mathrm{~cm}$ from the ulcer. Continuous US was given for 10 minutes.

Sham US group: sham US plus standard therapy

The ulcer was measured using planimetry at $2,4,6,8,10,12$
lated from the initial area and thereafter the daily ulcer radiu
tographs were taken at the same time points.
Ulcers completely healed at 12 weeks
Mean percentage decrease in ulcer area at 12 weeks
Adverse events: microbleeding and pain around the ulcer
Withdrawals by group and with reasons

Notes

No variance data supplied for continuous outcomes.

Duration of follow-up: 12 weeks

\section{Risk of bias}

\begin{tabular}{|c|c|c|}
\hline Bias & Authors' judgement & Support for judgement \\
\hline $\begin{array}{l}\text { Random sequence genera- } \\
\text { tion (selection bias) }\end{array}$ & Unclear risk & Quote: "Patients were randomised in parallel groups ..." \\
\hline $\begin{array}{l}\text { Allocation concealment } \\
\text { (selection bias) }\end{array}$ & Unclear risk & See above; no further information provided. \\
\hline $\begin{array}{l}\text { Blinding of participants } \\
\text { and personnel (perfor- } \\
\text { mance bias) } \\
\text { All outcomes }\end{array}$ & Unclear risk & $\begin{array}{l}\text { Participants: blinded via sham control } \\
\text { Personnel: almost certainly not blinded, quote: "The same procedure was se- } \\
\text { lected for the placebo treatment, but no ultrasound was generated during the } \\
10 \text { min footbath" }\end{array}$ \\
\hline $\begin{array}{l}\text { Blinding of outcome as- } \\
\text { sessment (detection bias) } \\
\text { All outcomes }\end{array}$ & Unclear risk & $\begin{array}{l}\text { Outcome assessors: unclear, } \\
\text { Quote: "the ulcer area was measured using planimetry ... prior to treatment } \\
\text { and after } 2,4,6,8,10 \text { and } 12 \text { weeks of therapy". }\end{array}$ \\
\hline $\begin{array}{l}\text { Incomplete outcome data } \\
\text { (attrition bias) } \\
\text { Ulcer healing }\end{array}$ & High risk & Two patients (both control group) were withdrawn due to "non-compliance". \\
\hline $\begin{array}{l}\text { Selective reporting (re- } \\
\text { porting bias) }\end{array}$ & Unclear risk & No details provided. \\
\hline Other bias & Unclear risk & No details provided. \\
\hline
\end{tabular}




Methods Randomised trial in an outpatients clinic in Poland

Participants

73 people with venous leg ulcers recruited after surgery for ligation and stripping (Babcock procedure) on saphenous or sagittal veins

Inclusion criteria: venous leg ulcer confirmed with Doppler ultrasound

Exclusion criteria: presence of diabetes, atherosclerosis or rheumatoid arthritis; steroid treatment; metal implants present at ultrasound application site; ulcer aetiology other than venous

Number of participants: US group: $n=24$; Compression group: $n=25$; Standard care group: $n=24$

Number of male:female participants: US group: 9:15; Compression group: 9:16; Standard care group: 13:11

Mean \pm SD (range) participant age in years: US group: $62.0 \pm 9.8$ (47-85); Compression group: $61.6 \pm 8.3$ (43-78); Standard care group: $62.3 \pm 9.5$ (40-79)

Number of participants with superficial vs superficial and deep venous insufficiency: US group: 9 vs 15; Compression group: 9 vs 16; Standard care group: 9 vs 15

Mean \pm SD ulcer area in $\mathrm{cm}^{2}$ : US group: $26.5 \pm 17.0$; Compression group: $24.4 \pm 12.9$; Standard care group: $22.0 \pm 15.5$

Mean \pm SD (range) ulcer duration in weeks: US group: $33 \pm 27$ (4-124); Compression group: $36 \pm 39$ (6-176); Standard care group: $32 \pm 35(2-120)$

Compression group: moist normal saline dressing, 2-component compression system comprising an elastic bandage (Sigvaris) applied at $30 \mathrm{~mm} \mathrm{Hg}$ ankle pressure for superficial venous insufficiency, and $40 \mathrm{~mm} \mathrm{Hg}$ for superficial and deep venous insufficiency (unclear whether pressure was verified) plus stocking (no further details of this) and pharmacotherapy as above

Standard care group: moist normal saline dressing plus pharmacotherapy as above

Treatment duration was 7 weeks for all participants.

Mean percentage change in ulcer area (relative to baseline) at 7 weeks
Mean percentage change in ulcer area/week (NB: values read from figure)
Mean \pm SD ulcer area in $\mathrm{cm}^{2}$ at 7 weeks
No secondary outcomes reported.
No report of withdrawals from the trial.

Notes

Ulcers assessed at baseline and weekly during treatment using a digitiser combined with computerised planimetry. In addition, ulcers were photographed (frequency and other details of this unclear).

No information provided about experience or skill of care providers.

Participants were the unit of randomisation.

Trial report was in Polish; we extracted data with the assistance of a translator.

\section{Risk of bias}


Taradaj 2007 (Continued)

\begin{tabular}{lll} 
Bias & Authors' judgement & Support for judgement \\
\hline $\begin{array}{l}\text { Random sequence genera- } \\
\text { tion (selection bias) }\end{array}$ & Unclear risk & From translator: " ... random assignment ..." \\
& & $\begin{array}{l}\text { Comment: no randomisation method specified. Authors did not state whether } \\
\text { participants were randomised before or after surgery. }\end{array}$ \\
\hline $\begin{array}{l}\text { Allocation concealment } \\
\text { (selection bias) }\end{array}$ & Unclear risk & No details provided.
\end{tabular}

Blinding of participants $\quad$ Unclear risk $\quad$ No details provided.
and personnel (perfor-
mance bias)
All outcomes

Blinding of outcome as- Unclear risk No details provided.

sessment (detection bias)

All outcomes

\begin{tabular}{|c|c|c|}
\hline $\begin{array}{l}\text { Incomplete outcome data } \\
\text { (attrition bias) } \\
\text { Ulcer healing }\end{array}$ & Unclear risk & $\begin{array}{l}\text { No report of withdrawals, and not clear from report whether all participants } \\
\text { were included in the analyses. }\end{array}$ \\
\hline
\end{tabular}

\begin{tabular}{lll}
\hline $\begin{array}{l}\text { Selective reporting (re- } \\
\text { porting bias) }\end{array}$ & Unclear risk & No details provided. \\
\hline Other bias & Unclear risk & No details provided. \\
\hline
\end{tabular}

Taradaj 2008

\begin{tabular}{ll}
\hline Methods & Randomised controlled trial in Poland. \\
\hline Participants & People assessed as having venous disease by assessment of symptoms and Duplex scanning. \\
& Number of participants: \\
& Surgery + US group: $\mathrm{n}=21 ;$ \\
& Surgery - US group: $\mathrm{n}=20 ;$ \\
& No surgery + US group: $\mathrm{n}=20 ;$ \\
& No surgery - US group: $\mathrm{n}=20$ \\
& Baseline characteristics: mean duration of ulcer (months) (SD): \\
& Surgery + US group: $32.04(22.12) ;$ \\
& Surgery - US group: $32.89(20.89) ;$ \\
& No surgery + US group: $30.99(20.09) ;$ \\
& No surgery - US group: $30.87(20.12)$ \\
& Mean baseline area (cm 2 ) (SD): \\
& Surgery + US group: $18.66(10.22) ;$ \\
& Surgery - US group: $18.02(10.72) ;$ \\
& No surgery + US group: $17.07(10.42) ;$ \\
& No surgery - US group: $18.06(11.09)$ \\
& Surog
\end{tabular}

Interventions

Surgery: as appropriate for each person included crossectomy, partial stripping of the greater or lesser saphenous veins, local phlebectomy and ligation of insufficient perforators. 
Taradaj 2008 (Continued)

Compression: Sigvaris compression stockings (30-40 $\mathrm{mmHg}$ at ankle)

Ultrasound: US $0.5 \mathrm{~W} / \mathrm{cm}^{2}$ pulsed; impulse $2 \mathrm{mS}$, interval $8 \mathrm{mS}$. Frequency $1 \mathrm{MHz}$. Performed in a bath of $34^{\circ} \mathrm{C}$ water. Probe head $10 \mathrm{~cm}^{2}$ placed $2 \mathrm{~cm}$ above ulcer. An ulcer of $5 \mathrm{~cm}^{2}$ or less had 5 minutes of treatment, with 1 minute of extra treatment for every $1 \mathrm{~cm}^{2}$ by which the ulcer exceeded an area of 5 $\mathrm{cm}^{2}$. Treatment occurred daily for 6 days/week for 7 weeks.

Drug therapy: flavonoids (450 mg diosmin, $50 \mathrm{mg}$ hesperidin), twice daily

Dressings: Ulcers covered with saline soaks. Dressings changed once daily in clinic.

\begin{tabular}{ll}
\hline Outcomes & $\begin{array}{l}\text { Treatment progress evaluated by observation of number of healed ulcers, measuring area by planime- } \\
\text { try by projecting image onto transparency paper using a digitising pallet. Measurements of area and } \\
\text { volume made at baseline, and before treatment each week. }\end{array}$ \\
\hline Notes & $\begin{array}{l}\text { Duration of follow-up } 7 \text { weeks. People who refused surgery were also randomised to US or standard } \\
\text { care. }\end{array}$
\end{tabular}

\section{Risk of bias}

\begin{tabular}{lll}
\hline Bias & Authors' judgement & Support for judgement \\
\hline $\begin{array}{l}\text { Random sequence genera- } \\
\text { tion (selection bias) }\end{array}$ & Unclear risk & $\begin{array}{l}\text { Quote: "In this randomised controlled clinical trial ...”. Method of randomisa- } \\
\text { tion not stated. }\end{array}$ \\
\hline $\begin{array}{l}\text { Allocation concealment } \\
\text { (selection bias) }\end{array}$ & Unclear risk & $\begin{array}{l}\text { Quote: "Eighty one patients with venous leg ulcers were included ... Forty one } \\
\text { individuals - who agreed on surgical operation ... were ultimately allocated in- } \\
\text { to two comparative groups 1 and 2. Other individuals - who did not agree on } \\
\text { surgical procedure - were ultimately allocated into two comparative groups 3 } \\
\text { and 4..." }\end{array}$
\end{tabular}

\begin{tabular}{|c|c|c|}
\hline $\begin{array}{l}\text { Blinding of participants } \\
\text { and personnel (perfor- }\end{array}$ & High risk & $\begin{array}{l}\text { Participants: not blinded, since study was not sham controlled. } \\
\text { Personnel: not blinded, see above. }\end{array}$ \\
\hline
\end{tabular}

mance bias)

All outcomes

Blinding of outcome as-
sessment (detection bias) $\quad$ High risk Outcome assessors: almost certainly not blinded

sessment (detection bias)

All outcomes

\begin{tabular}{lll}
\hline $\begin{array}{l}\text { Incomplete outcome data } \\
\text { (attrition bias) } \\
\text { Ulcer healing }\end{array}$ & Unclear risk & $\begin{array}{l}\text { Not mentioned. Withdrawals not mentioned (100\% follow-up implied but not } \\
\text { stated). }\end{array}$ \\
\hline $\begin{array}{l}\text { Selective reporting (re- } \\
\text { porting bias) }\end{array}$ & Unclear risk & No details provided. \\
\hline Other bias & Unclear risk & No details provided. \\
\hline
\end{tabular}

\section{Watson 2011}

\begin{tabular}{ll}
\hline Methods & Randomised controlled trial in a variety of settings in UK and Ireland. \\
\hline Participants & 337 people with hard to heal venous leg ulcers (defined as more than 6 months' duration or area \\
& greater than $5 \mathrm{~cm}^{2}$ or both); $\mathrm{ABPI} \geq 0.8$. \\
& Variety of settings in UK and Ireland (community nursing services, hospital outpatients clinics). \\
& US group: $\mathrm{n}=168 ;$
\end{tabular}


Watson 2011 (Continued)

Standard care group: $\mathrm{n}=169$

Interventions US group: low dose $\left(0.5 \mathrm{~W} / \mathrm{cm}^{2}\right)$ ultrasound at $1 \mathrm{MHz}$ with a pulsed pattern of 1:4 applied to the periulcer skin (using a water-based contact gel) once a week for up to 12 weeks plus standard care.

US was applied for a period of 5-10 minutes per treatment to the reference ulcer; the actual time being determined by a protocol based on ulcer area.

Standard care group: simple low adherent dressing and high compression (4-layer bandaging), reduced compression or no compression according to the clinician's assessment of the level of pressure tolerated by the participant

Time to healing of the reference ulcer
Cost effectiveness
Proportion of participants with healed ulcers at 3, 6, 12 months
Percentage and absolute change in ulcer size
HRQoL and adverse events

Notes Maximal duration of follow-up was of 12 months.

\section{Risk of bias}

Bias Authors' judgement Support for judgement

Random sequence genera- Low risk tion (selection bias)

Quote: "Participants were randomised equally between the two trial arms: ultrasound plus standard care and standard care alone. Randomisation was carried out using varying block sizes of four and six participants ... The computerised randomisation system was checked periodically during the trial following standard operating procedures."

\begin{tabular}{ll}
\hline $\begin{array}{l}\text { Allocation concealment } \\
\text { (selection bias) }\end{array}$ & Low risk \\
& $\begin{array}{l}\text { Quote: "To maintain allocation concealment the generation of the randomi- } \\
\text { sation sequence and subsequent treatment allocation were performed by an } \\
\text { independent, secure, remote, telephone randomisation service (York Trials } \\
\text { Unit)." }\end{array}$
\end{tabular}

\begin{tabular}{|c|c|c|}
\hline $\begin{array}{l}\text { Blinding of participants } \\
\text { and personnel (perfor- } \\
\text { mance bias) }\end{array}$ & High risk & $\begin{array}{l}\text { Quote: "Owing to the nature of the intervention, it was not possible to con- } \\
\text { ceal the treatment allocation from either the patient or the nurse" This lack of } \\
\text { blinding leaves the study susceptible to performance bias. }\end{array}$ \\
\hline
\end{tabular}

All outcomes

\section{Blinding of outcome as- Low risk} sessment (detection bias) All outcomes

(n)

Quote for 12-week outcome: "The reference ulcer was the largest ulcer on either leg (as assessed at the time of trial entry). The date of healing was recorded by the research nurses on the Ulcer Healed Form and the photographs of the reference ulcer were assessed independently by two people blind to treatment group. Any disagreements were resolved by discussion or referral to a third blinded assessor. The primary outcome was calculated using the date of healing as decided by the blind assessors. If the blinded assessors did not agree on a healing date, then the date as recorded on the Ulcer Healed Form was used."

This blinded, remote adjudication of healing reduced the risk of detection bias. It is difficult to accurately judge the risk of bias in this scenario because an unmasked research nurse took a photograph. However, the blinded adjudication gives some reassurance that the risk of detection bias is low. 
12-month outcome: unclear. Quote: "The number of leg ulcers that had completely healed by 12 months was based on nurse-reported data and not on blinded photographs ..."

Incomplete outcome data Low risk (attrition bias)

Ulcer healing

Quote: "Time to healing was derived as the number of days between randomisation and the first date that healing was confirmed. Patients who withdrew unhealed from the trial or died prior to healing were treated as censored in the analysis. Their time to censoring was derived using the date of trial exit, the date of their last ulcer assessment or the date of trial closure." Participants who completed the full 12-month follow-up without their reference ulcer healing were treated as censored and their time to censoring was calculated as 12 months (365 days).

Quote: "All randomised participants were included in the analysis and numbers of full withdrawals were low (only 10 patients ceased contributing data on the primary endpoint)."

Analysis was by intention to treat.

$\begin{aligned} & \text { Selective reporting (re- } \\ & \begin{array}{l}\text { porting bias) } \\ \text { Low risk }\end{array}\end{aligned} \quad \begin{aligned} & \text { A full protocol was available and the published trial followed the protocol. } \\ & \text { Amendments to the original protocol were detailed and justified. }\end{aligned}$

Other bias Low risk No other serious bias.

\section{Weichenthal 1997}

\begin{tabular}{|c|c|c|}
\hline Methods & \multicolumn{2}{|c|}{ Randomised controlled trial in Germany. } \\
\hline \multirow[t]{4}{*}{ Participants } & \multicolumn{2}{|c|}{ People admitted to an outpatient clinic for chronic leg ulcers. } \\
\hline & \multirow{3}{*}{\multicolumn{2}{|c|}{$\begin{array}{l}38 \text { participants with chronic venous leg ulceration of } 3 \text { months minimum duration plus evidence of in- } \\
\text { competent perforating or superficial veins } \\
\text { US group: } n=19 \text {; } \\
\text { Conventional therapy group: } n=18\end{array}$}} \\
\hline & & \\
\hline & & \\
\hline Interventions & \multirow{2}{*}{\multicolumn{2}{|c|}{$\begin{array}{l}\text { US group: } 30 \mathrm{kHz} \text {, intensity } 0.1 \mathrm{~W} / \mathrm{cm}^{2} \text { for } 10 \text { minutes, delivered via the indirect (water-bath) method, } \\
\text { plus conventional therapy } \\
\text { Conventional therapy group: conventional therapy of fibrinolytic agents, antibiotics, or other antisep- } \\
\text { tic agents, plus "generally compression therapy performed with elastic bandages" }\end{array}$}} \\
\hline & & \\
\hline Outcomes & \multirow{4}{*}{\multicolumn{2}{|c|}{$\begin{array}{l}\text { Number of ulcers healed at } 8 \text { weeks } \\
\text { Mean percentage of initial ulcer area present at } 8 \text { weeks } \\
\text { Withdrawals by group and with reasons } \\
\text { Adverse events reported as pain and erythema (reported for US group only) }\end{array}$}} \\
\hline & & \\
\hline & & \\
\hline & & \\
\hline Notes & \multicolumn{2}{|c|}{ Duration of follow-up: 8 weeks } \\
\hline \multicolumn{3}{|l|}{ Risk of bias } \\
\hline Bias & Authors' judgement & Support for judgement \\
\hline $\begin{array}{l}\text { Random sequence genera- } \\
\text { tion (selection bias) }\end{array}$ & Low risk & $\begin{array}{l}\text { Quote: "Each patient was randomly assigned to receive ...", and "Randomisa- } \\
\text { tion was performed with sequential treatment cards which labelled the pa- } \\
\text { tient as either control or treatment. The cards were produced with a computer } \\
\text { random number generator, preserving balance for each group" }\end{array}$ \\
\hline
\end{tabular}


Weichenthal 1997 (Continued)

\begin{tabular}{l}
$\begin{array}{l}\text { Allocation concealment } \\
\text { (selection bias) }\end{array}$ \\
\hline
\end{tabular}

\begin{tabular}{|c|c|c|}
\hline $\begin{array}{l}\text { Blinding of participants } \\
\text { and personnel (perfor- } \\
\text { mance bias) } \\
\text { All outcomes }\end{array}$ & High risk & $\begin{array}{l}\text { Participants: no blinding, since study was not sham controlled. } \\
\text { Personnel: see above. }\end{array}$ \\
\hline $\begin{array}{l}\text { Blinding of outcome as- } \\
\text { sessment (detection bias) } \\
\text { All outcomes }\end{array}$ & High risk & Outcome assessors: highly unlikely that outcome assessors were blinded \\
\hline $\begin{array}{l}\text { Incomplete outcome data } \\
\text { (attrition bias) } \\
\text { Ulcer healing }\end{array}$ & Unclear risk & $\begin{array}{l}1 \text { ineligible participant was excluded from the analysis, quote: "Within the con- } \\
\text { trol group only } 18 \text { patients were evaluated for the study endpoints because at } \\
\text { the end of the study evidence of arterial vascular disease was present in one } \\
\text { patient, who was therefore excluded from the evaluation." Otherwise com- } \\
\text { plete follow-up and analysis by intention-to-treat analysis implied, but not } \\
\text { stated. }\end{array}$ \\
\hline
\end{tabular}

\begin{tabular}{lll}
\hline $\begin{array}{l}\text { Selective reporting (re- } \\
\text { porting bias) }\end{array}$ & Unclear risk & No details provided. \\
\hline Other bias & Unclear risk & No details provided. \\
\hline
\end{tabular}

\author{
Abbreviations \\ $>=$ greater than \\ $\geq=$ greater than or equal to \\ $\mathrm{ABPI}=$ ankle-brachial pressure index \\ $\mathrm{HRQ}$ oL: health-related quality of life \\ $\mathrm{n}=$ number of participants in group(s) \\ $\mathrm{RCT}=$ randomised controlled trial \\ $\mathrm{SD}=$ standard deviation \\ US $=$ ultrasound \\ $\mathrm{mS}=$ millisiemens
}

Characteristics of excluded studies [ordered by study ID]

\begin{tabular}{ll}
\hline Study & Reason for exclusion \\
\hline Dissemond 2003 & Not a trial \\
\hline Dyson 1976 & Not a randomised trial \\
\hline Kavros 2007a & Trial predominantly involved people with ulcers secondary to critical limb ischaemia. \\
\hline Kavros 2007b & Trial was an open-label, non-randomised, baseline-controlled clinical case series. \\
\hline Roche 1984 & Not a randomised trial \\
\hline Tan 2007 & Non-controlled pilot study \\
\hline
\end{tabular}

\title{
Characteristics of studies awaiting assessment [ordered by study ID]
}


White 2016

\begin{tabular}{|c|c|}
\hline Methods & $\begin{array}{l}\text { A UK-based, assessor-blinded, randomised, controlled trial, conducted in a single dedicated unit } \\
\text { specialising in wound healing research. The trial consisted of a 4-week run-in phase, followed by an } \\
\text { 8-week treatment phase. }\end{array}$ \\
\hline Participants & $\begin{array}{l}\text { Adults with chronic venous leg ulcers (duration } \geq 6 \text { weeks and } \leq 5 \text { years, and area } 5 \mathrm{~cm}^{2}-100 \mathrm{~cm}^{2} \\
\text { at randomisation) and an ABPI of }>0.8 \text {. Those whose wounds reduced by }>40 \% \text { during the first } 4 \\
\text { weeks (the run-in phase) did not progress to randomisation. } 36 \text { people were randomised. } \\
\text { US group: } n=17 ; \\
\text { Standard care group: } n=19\end{array}$ \\
\hline Interventions & $\begin{array}{l}\text { US group: non-contact low-frequency US (NLFU) + standard care (SOC) } 3 \text { times a week. NLFU con- } \\
\text { sisted of the application of MIST US therapy (Therapy System; Celleration Inc., Eden Prairie, MN) } \\
\text { to a clean wound bed for 3-12 minutes (depending on the wound area) } 3 \text { times a week for up to } 8 \\
\text { weeks; a non-adherent dressing and strong compression therapy was applied after NLFU applica- } \\
\text { tion. Standard care alone at least once a week. }\end{array}$ \\
\hline Outcomes & $\begin{array}{l}\text { The primary outcome was the change in wound area from baseline (week 5) to week } 13 \text { (or the } \\
\text { point of healing) controlling for the baseline wound area measurement. } \\
\text { Secondary outcomes were change in HRQoL from enrolment to week } 13 \text { (or point of healing), inci- } \\
\text { dence of clinical infection, pain (assessed with a visual analogue scale), and wound characteristics } \\
\text { (e.g. odour, exudate, wound bed characteristics). The proportion of healed wounds that remained } \\
\text { closed } 90 \text { days later was recorded. }\end{array}$ \\
\hline Notes & $\begin{array}{l}\text { We are seeking independent guidance as to whether this is a distinct intervention for the purpose } \\
\text { of debridement. }\end{array}$ \\
\hline
\end{tabular}

\section{Abbreviations}

$\mathrm{ABPI}=$ ankle-brachial pressure index $\mathrm{HRQOL}=$ health-related quality of life NLFU: non-contact low-frequency US = ultrasound

\section{DATA AND ANALYSES}

\section{Comparison 1. High frequency US vs no US}

\begin{tabular}{|c|c|c|c|c|}
\hline Outcome or subgroup title & No. of studies & $\begin{array}{l}\text { No. of partici- } \\
\text { pants }\end{array}$ & Statistical method & Effect size \\
\hline $\begin{array}{l}1 \text { Proportion of ulcers completely } \\
\text { healed at } 3 \text { weeks }\end{array}$ & 1 & & $\begin{array}{l}\text { Risk Ratio (M-H, Fixed, 95\% } \\
\mathrm{Cl} \text { ) }\end{array}$ & $\begin{array}{l}\text { Totals not select- } \\
\text { ed }\end{array}$ \\
\hline $\begin{array}{l}2 \text { Proportion of ulcers completely } \\
\text { healed at } 7 \text { or } 8 \text { weeks }\end{array}$ & 6 & & $\begin{array}{l}\text { Risk Ratio (M-H, Random, } \\
95 \% \mathrm{Cl})\end{array}$ & Subtotals only \\
\hline 2.1 Losses as unhealed & 6 & 678 & $\begin{array}{l}\text { Risk Ratio (M-H, Random, } \\
95 \% \mathrm{Cl})\end{array}$ & $1.21[0.86,1.71]$ \\
\hline 2.2 Complete case analysis & 6 & 627 & $\begin{array}{l}\text { Risk Ratio (M-H, Random, } \\
95 \% \mathrm{Cl})\end{array}$ & $1.21[0.88,1.67]$ \\
\hline $\begin{array}{l}3 \text { Proportion of ulcers completely } \\
\text { healed at } 12 \text { weeks }\end{array}$ & 3 & & $\begin{array}{l}\text { Risk Ratio (M-H, Fixed, 95\% } \\
\mathrm{Cl})\end{array}$ & Subtotals only \\
\hline
\end{tabular}




\begin{tabular}{|c|c|c|c|c|}
\hline Outcome or subgroup title & No. of studies & $\begin{array}{l}\text { No. of partici- } \\
\text { pants }\end{array}$ & Statistical method & Effect size \\
\hline 3.1 Losses as unhealed & 3 & 489 & $\begin{array}{l}\text { Risk Ratio (M-H, Fixed, 95\% } \\
\mathrm{Cl})\end{array}$ & $1.26[0.92,1.73]$ \\
\hline 3.2 Complete case analysis & 3 & 451 & $\begin{array}{l}\text { Risk Ratio (M-H, Fixed, 95\% } \\
\mathrm{Cl} \text { ) }\end{array}$ & $1.20[0.89,1.62]$ \\
\hline $\begin{array}{l}4 \text { Proportion of ulcers completely } \\
\text { healed at } 12 \text { months (nurse-reported } \\
\text { data) }\end{array}$ & 1 & & $\begin{array}{l}\text { Risk Ratio (M-H, Fixed, 95\% } \\
\mathrm{Cl})\end{array}$ & $\begin{array}{l}\text { Totals not select- } \\
\text { ed }\end{array}$ \\
\hline $\begin{array}{l}5 \text { HRQoL: } 12 \text {-week SF-12 Physical } \\
\text { Component Score }\end{array}$ & 1 & & $\begin{array}{l}\text { Mean Difference (IV, Fixed, } \\
95 \% \mathrm{CI})\end{array}$ & $\begin{array}{l}\text { Totals not select- } \\
\text { ed }\end{array}$ \\
\hline $\begin{array}{l}6 \mathrm{HRQ} \text { oL: } 12 \text {-week SF-12 Mental Com- } \\
\text { ponent Score }\end{array}$ & 1 & & $\begin{array}{l}\text { Mean Difference (IV, Fixed, } \\
95 \% \mathrm{CI})\end{array}$ & $\begin{array}{l}\text { Totals not select- } \\
\text { ed }\end{array}$ \\
\hline $\begin{array}{l}7 \mathrm{HRQ} \text { oL: } 12 \text {-month SF-12 Physical } \\
\text { Component Score }\end{array}$ & 1 & & $\begin{array}{l}\text { Mean Difference (IV, Fixed, } \\
95 \% \mathrm{CI})\end{array}$ & $\begin{array}{l}\text { Totals not select- } \\
\text { ed }\end{array}$ \\
\hline $\begin{array}{l}8 \mathrm{HRQ} \text { L: } 12 \text {-month SF-12 Mental } \\
\text { Component Score }\end{array}$ & 1 & & $\begin{array}{l}\text { Mean Difference (IV, Fixed, } \\
95 \% \mathrm{CI})\end{array}$ & $\begin{array}{l}\text { Totals not select- } \\
\text { ed }\end{array}$ \\
\hline $\begin{array}{l}9 \text { Non-serious and serious adverse } \\
\text { events }\end{array}$ & 1 & & $\begin{array}{l}\text { Risk Ratio (M-H, Fixed, 95\% } \\
\mathrm{Cl})\end{array}$ & $\begin{array}{l}\text { Totals not select- } \\
\text { ed }\end{array}$ \\
\hline 9.1 Non-serious adverse events & 1 & & $\begin{array}{l}\text { Risk Ratio (M-H, Fixed, 95\% } \\
\mathrm{Cl})\end{array}$ & $0.0[0.0,0.0]$ \\
\hline 9.2 Serious adverse events & 1 & & $\begin{array}{l}\text { Risk Ratio (M-H, Fixed, 95\% } \\
\mathrm{Cl} \text { ) }\end{array}$ & $0.0[0.0,0.0]$ \\
\hline
\end{tabular}

Analysis 1.1. Comparison 1 High frequency US vs no US, Outcome 1 Proportion of ulcers completely healed at 3 weeks.

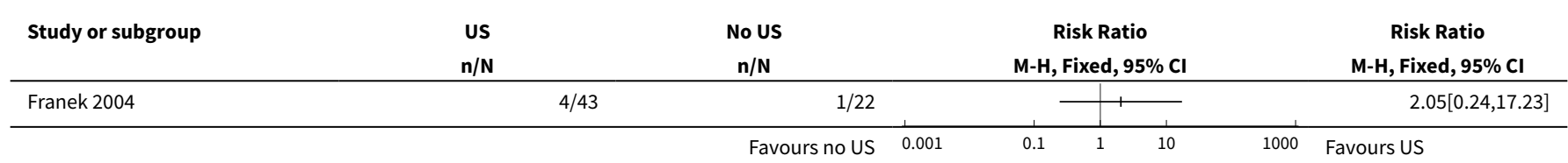

\section{Analysis 1.2. Comparison 1 High frequency US vs no US, Outcome} 2 Proportion of ulcers completely healed at 7 or $\mathbf{8}$ weeks.

\begin{tabular}{|c|c|c|c|c|c|}
\hline Study or subgroup & $\begin{array}{c}\text { US } \\
n / N\end{array}$ & $\begin{array}{c}\text { No US } \\
n / N\end{array}$ & $\begin{array}{c}\text { Risk Ratio } \\
\text { M-H, Random, } 95 \% \text { Cl }\end{array}$ & Weight & $\begin{array}{c}\text { Risk Ratio } \\
\text { M-H, Random, 95\% Cl }\end{array}$ \\
\hline \multicolumn{6}{|c|}{ 1.2.1 Losses as unhealed } \\
\hline Watson 2011 & $9 / 168$ & $15 / 169$ & $\rightarrow$ & $16.07 \%$ & $0.6[0.27,1.34]$ \\
\hline Dolibog 2008 & $10 / 33$ & $12 / 37$ & $\rightarrow$ & $20.33 \%$ & $0.93[0.47,1.87]$ \\
\hline Taradaj 2008 & $12 / 41$ & $9 / 40$ & $\rightarrow$ & $18.04 \%$ & $1.3[0.62,2.74]$ \\
\hline
\end{tabular}




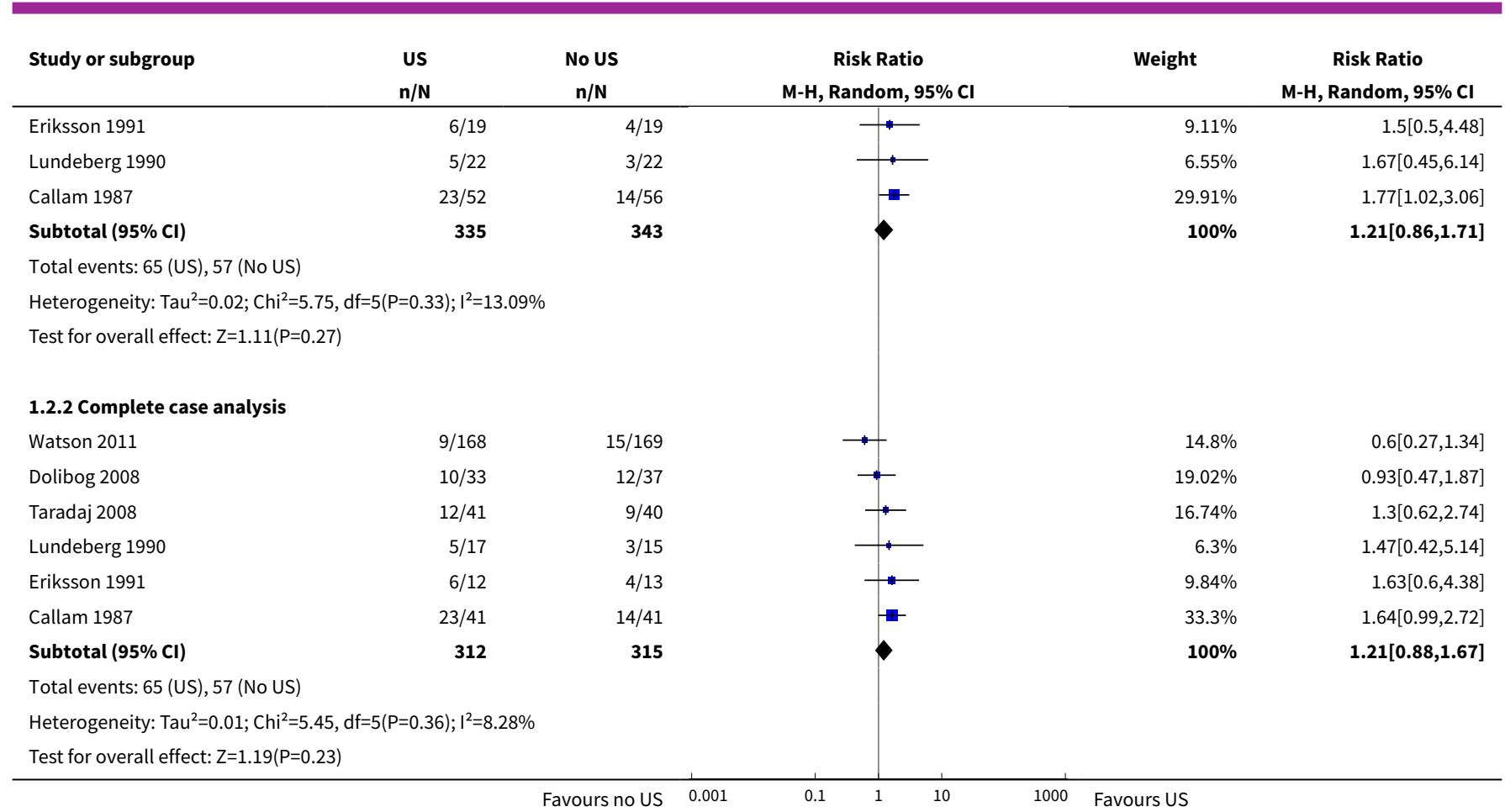

Analysis 1.3. Comparison 1 High frequency US vs no US, Outcome 3 Proportion of ulcers completely healed at 12 weeks.

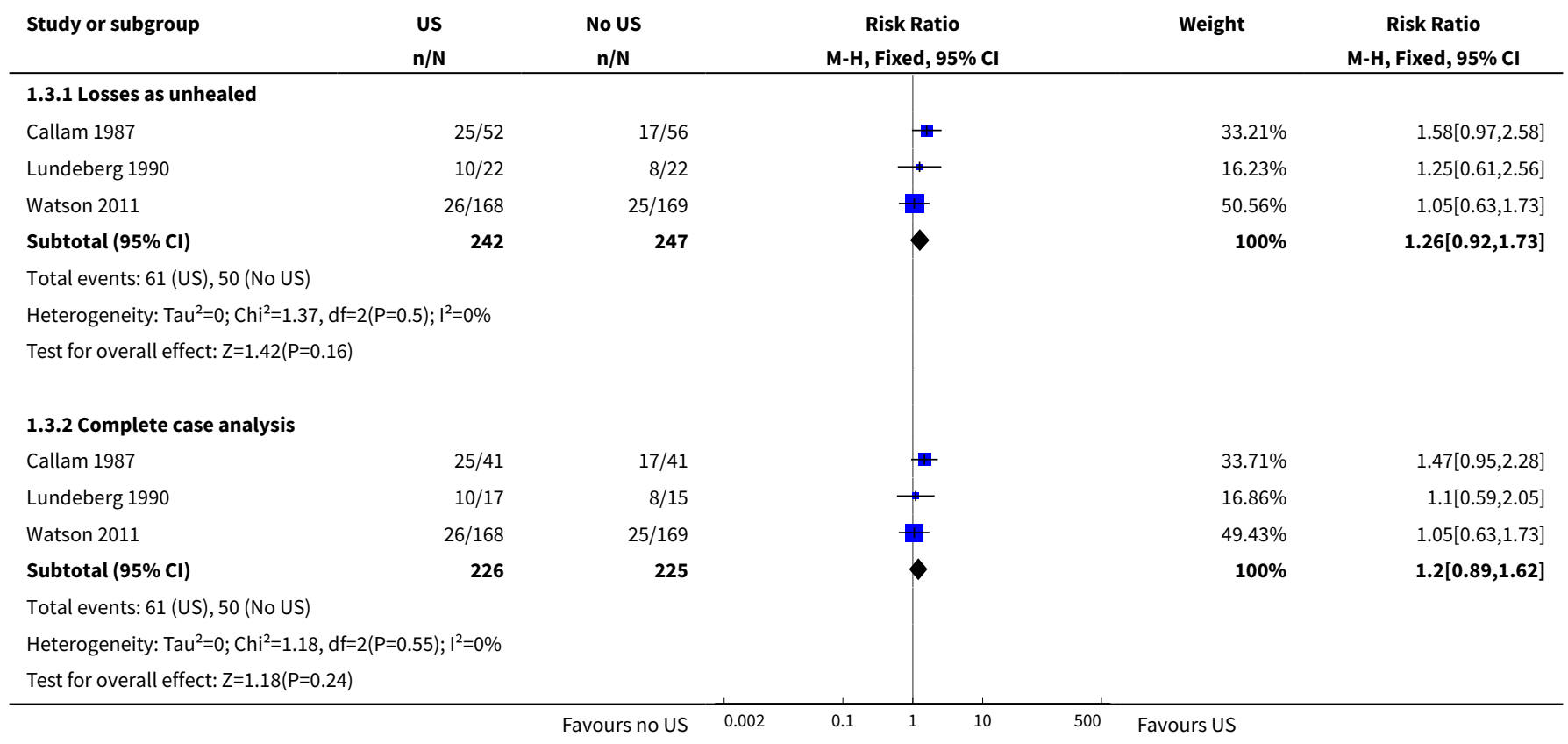

Therapeutic ultrasound for venous leg ulcers (Review) 
Analysis 1.4. Comparison 1 High frequency US vs no US, Outcome 4

Proportion of ulcers completely healed at 12 months (nurse-reported data).

\begin{tabular}{|c|c|c|c|c|}
\hline Study or subgroup & $\begin{array}{l}\text { US } \\
n / N\end{array}$ & $\begin{array}{l}\text { No US } \\
n / N\end{array}$ & $\begin{array}{c}\text { Risk Ratio } \\
\text { M-H, Fixed, } 95 \% \text { Cl }\end{array}$ & $\begin{array}{c}\text { Risk Ratio } \\
\text { M-H, Fixed, } 95 \% \mathrm{Cl}\end{array}$ \\
\hline Watson 2011 & $72 / 168$ & $78 / 169$ & 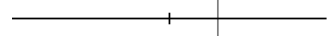 & $0.93[0.73,1.18]$ \\
\hline
\end{tabular}

Analysis 1.5. Comparison 1 High frequency US vs no US, Outcome 5 HRQoL: 12-week SF-12 Physical Component Score.

\begin{tabular}{|c|c|c|c|c|c|c|}
\hline \multirow[t]{2}{*}{ Study or subgroup } & \multicolumn{2}{|c|}{ US } & \multicolumn{2}{|c|}{ No US } & \multirow{2}{*}{$\begin{array}{l}\text { Mean Difference } \\
\text { Fixed, } 95 \% \mathrm{Cl}\end{array}$} & \multirow{2}{*}{$\begin{array}{c}\text { Mean Difference } \\
\text { Fixed, } 95 \% \mathrm{Cl}\end{array}$} \\
\hline & $\mathbf{N}$ & $\operatorname{Mean}(\mathrm{SD})$ & $\mathbf{N}$ & $\operatorname{Mean}(\mathrm{SD})$ & & \\
\hline Watson 2011 & 143 & 33.9 (11.5) & 142 & $35(11.4)$ & $1-$ & $-1.09[-3.75,1.57]$ \\
\hline
\end{tabular}

Analysis 1.6. Comparison 1 High frequency US vs no US, Outcome 6 HRQoL: 12-week SF-12 Mental Component Score.

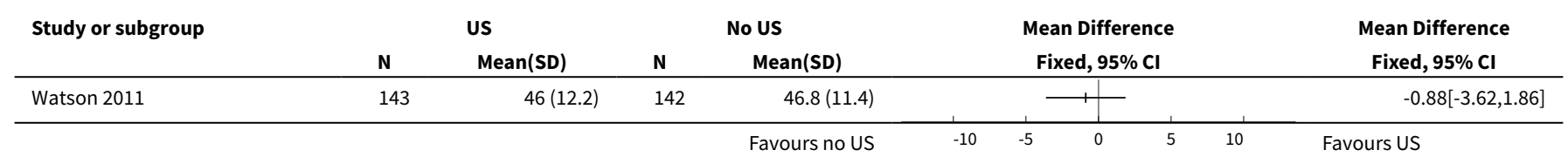

Analysis 1.7. Comparison 1 High frequency US vs no US, Outcome 7 HRQoL: 12-month SF-12 Physical Component Score.

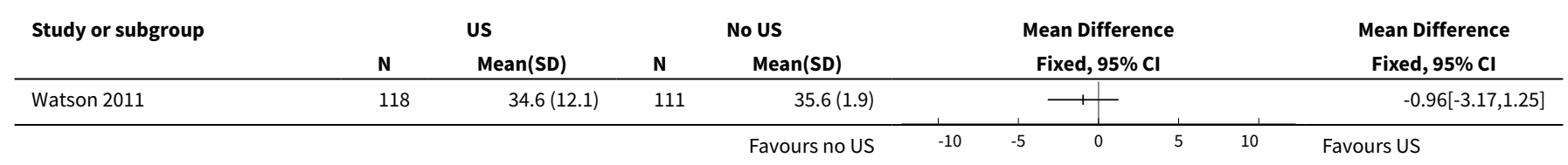

Analysis 1.8. Comparison 1 High frequency US vs no US, Outcome 8 HRQoL: 12-month SF-12 Mental Component Score.

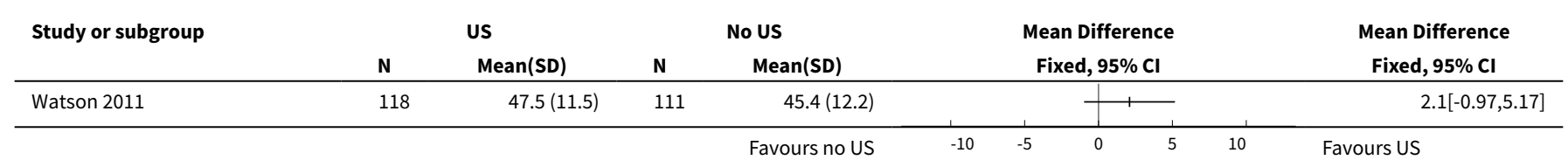


Analysis 1.9. Comparison 1 High frequency US vs no US, Outcome 9 Non-serious and serious adverse events.

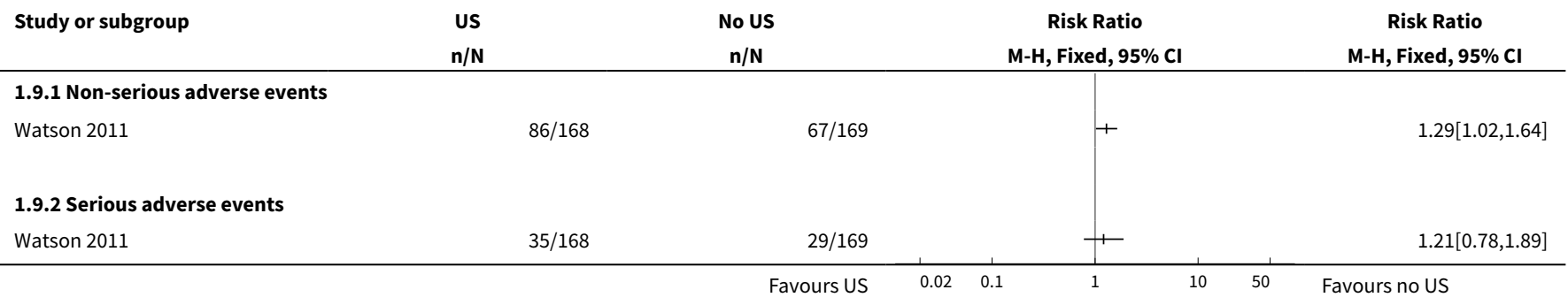

\section{Comparison 2. Low frequency US vs no US}

\begin{tabular}{lllll}
\hline Outcome or subgroup title & No. of studies & $\begin{array}{l}\text { No. of partici- } \\
\text { pants }\end{array}$ & Statistical method & Effect size \\
\hline $\begin{array}{l}\text { 1 Proportion of ulcers completely healed at } \\
8-12 \text { weeks }\end{array}$ & 61 & 6 & $\begin{array}{l}\text { Risk Ratio (M-H, Fixed, } \\
95 \% \mathrm{Cl})\end{array}$ & $3.91[0.47,32.85]$ \\
\hline
\end{tabular}

Analysis 2.1. Comparison 2 Low frequency US vs no US, Outcome 1 Proportion of ulcers completely healed at 8-12 weeks.

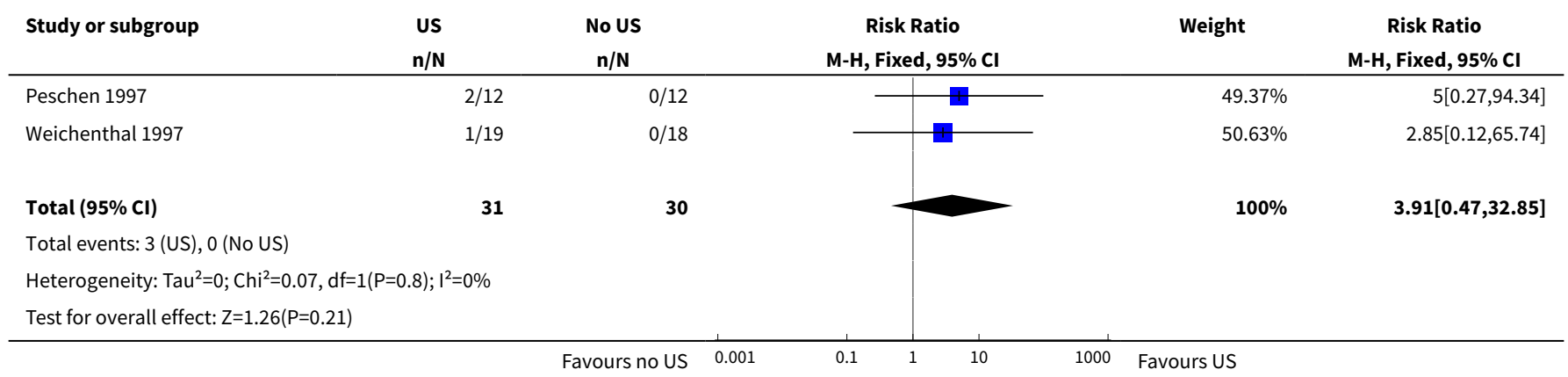

ADDITIONAL TABLES

Table 1. Data extraction table

\begin{tabular}{|c|c|c|c|c|}
\hline Study & $\begin{array}{l}\text { Intervention and Co-in- } \\
\text { terventions }\end{array}$ & $\begin{array}{l}\text { Comparison inter- } \\
\text { vention }\end{array}$ & Participants & Results \\
\hline Callam 1987 & \multirow{2}{*}{$\begin{array}{l}\text { US group }(n=52) \text { : } \\
\text { DIRECT and HIGH FRE- } \\
\text { QUENCY }\end{array}$} & \multirow{4}{*}{$\begin{array}{l}\text { Standard treatment } \\
\text { group ( } \mathrm{n}=56) \text { : } \\
\text { cleansing with } 1 \% \\
\text { saline; application } \\
\text { of } \text { Arachis oil to } \\
\text { skin without mas- } \\
\text { sage; application of } \\
\text { paste bandage (Cal- } \\
\text { aband); application }\end{array}$} & \multirow{2}{*}{$\begin{array}{l}\text { Included: pa- } \\
\text { tients attending } \\
\text { clinics for treat- } \\
\text { ment of chronic } \\
\text { leg ulcers }\end{array}$} & Ulcers completely healed by 12 wks: \\
\hline $\begin{array}{l}5 \text { physiotherapy } \\
\text { departments }\end{array}$ & & & & $\begin{array}{l}\text { US: } 25 / 52(48 \%) \\
\text { C: } 17 / 56(30 \%)\end{array}$ \\
\hline Scotland & $\begin{array}{l}\text { *Lancet paper reports this } \\
\text { frequency as } 1 \mathrm{mHz} \text {. Veri- } \\
\text { fied with M Callam in Dec }\end{array}$ & & $\begin{array}{l}\text { Excluded: non } \\
\text { consent, aller- } \\
\text { gy to standard }\end{array}$ & Read from graph: \\
\hline & & & treatment, PVD & Ulcers completely healed at 8 wks: \\
\hline
\end{tabular}

Therapeutic ultrasound for venous leg ulcers (Review) 
Table 1. Data extraction table (Continued) 09 that this should have read $1 \mathrm{MHz}$.

NB 2 related abstracts say there were 110 participants of support bandage (Lestreflex); advice on exercise.

Weekly treatment.

(lack of ankle pulses)

US: $23 / 52(45 \%)$

C: $14 / 56(25 \%)$

Ulcers completely healed by 12 wks (complete case):

US: $25 / 41$ (61\%)

C: $17 / 41(41 \%)$

US treated healed sig more quickly by log rank $;=0.03$. this effect persisted even when withdrawals due to pain and deterioration counted as failures.

Mean $\%$ ulcer unhealed at 12 weeks (no variance):

US: $9 \%$

C: $27 \%$

$\mathrm{P}<0.05$

Withdrawals:

US: $11 / 52(21 \%)$

Allergy 4

Pain 4

DNA/refused 2

Death 2

C: $15 / 56(27 \%)$

Allergy 6

Pain 3

Refused/DNA 3

Deterioration 2

Arterial disease 1

$\begin{array}{ll}\text { Dolibog } 2008 & \text { US group: } 33 \text { participants } \\ & \text { treated with US, compres- } \\ & \text { sion (Sigvaris), and drug } \\ & \text { therapy. }\end{array}$

Poland

Standard care group $(\mathrm{n}=37)$ : compression and drug therapy.

Dressings changed daily for 7 weeks.
70 participants with venous leg ulcers who all had venous surgery, and diagnosed as having venous dis-
Ulcers healed completely:

Group 1: 10/33

Group 2: 12/37

Therapeutic ultrasound for venous leg ulcers (Review) 
Table 1. Data extraction table (Continued) INDIRECT and HIGH FREQUENCY mary care

Sweden

Eriksson 1991
Hospital and pri-
mary care

US group: $1.0 \mathrm{~W} / \mathrm{cm}^{2}$ at 1 $\mathrm{MHz}$. Enraf Nonius US machine with aquasonic gel. Ultrasound head was 2.8 $\mathrm{cm}$ diameter for superficial ulcers and $1.2 \mathrm{~cm}$ diameter for deep ulcers. US applied to ulcer surface area and surrounding tissue for 10 minutes twice a week for 8 weeks.

DIRECT and HIGH FREQUENCY ease with Duplex scanning.

Excluded: diabetes, rheumatoid arthritis

Surgery included crossectomy, partial stripping of GSV or LSV, local phlebectomy, ligation of perforators.

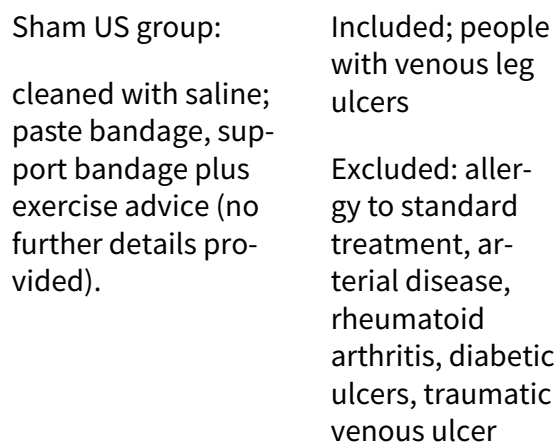

Mean area after therapy (SD)

Group 1: 13.15 (11.55)

Group 2: 13.12 (14.57)
Ulcers completely healed at 8 wks:

US: 6/19 (6/12 completers)

C: 4/19 (4/13 completers)

Cumulative \% healed compared using life table methods.

$\%$ ulcers completely healed at different times (wks) US:C

2 wks: 8:0

4 wks: $17: 8$

6 wks: $25: 15$

8 wks: $41: 30$

$\%$ ulcer area healed at 8 wks (SD):

US: $42(9)$

C: $48(13)$

Withdrawals:

US: $7 / 19$

C: $6 / 19$

For allergy:

US: 3

C: 2 
Table 1. Data extraction table (Continued)

For pain:

US: 2

C: 1

Refusal/DNA:

US: 2

C: 3

\section{Franek 2004}

US group 1: US at $1 \mathrm{~W} / \mathrm{cm}^{2}$
$(n=22)$

US group 2: US at $0.5 \mathrm{~W} /$ $\mathrm{cm}^{2}(\mathrm{n}=21)$

Poland

Hospital inpatients

Both groups received pulsed cycle of $1: 5$, frequency $1 \mathrm{MHz}$.

Cointerventions: saline soaked gauze. Single-layer elastic compression (Hartmann).

INDIRECT and HIGH FREQUENCY
Pharmacotherapy group ( $n=22)$ : no US. Local baths of potassium permanganate and wet dressings of $0.1 \mathrm{M}$ copper sulphate solution plus compresses of fibrolan, chloramphenicol, colistin, gentamicin. Drugs alternated every few days. Single layer elastic compression (Hartmann). Treatment for 3 weeks.

This was problematic as the use of US or not was not the only difference in treatment between the groups i.e. performance bias. Also US groups 1 and 2 were hospitalised in the Dermatology Clinic of Katowice and Group $C$ in the Dermatology Dept of Zabrze.
Included: people with venous ulcers (signs of venous disease) and ABPI > 1.0. Excluded: people with diabetes, advanced sclerosis

Mean (median) area after treatment $\left(\mathrm{cm}^{2}\right)$ :

A: $14(11.14) p=0.0001$

B: $9.29(3.78) p=0.00006$

$C: 20.58(9.86) p=0.002$

Complete ulcer healing by 3 weeks:
A: $1 / 22$
B: $3 / 21$
C: $1 / 22$

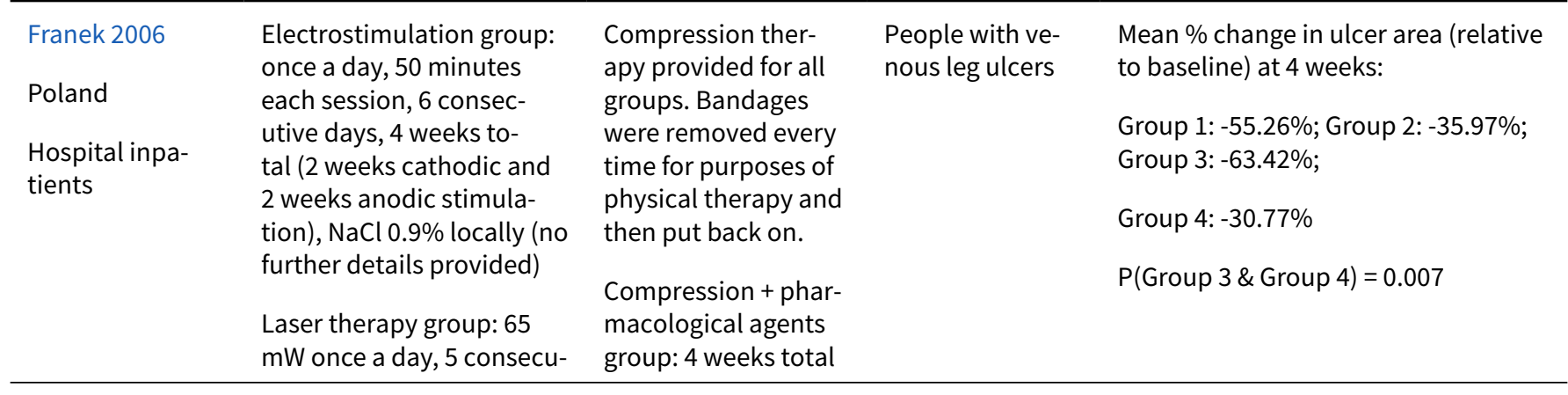

Therapeutic ultrasound for venous leg ulcers (Review) 
Table 1. Data extraction table (Continued) tive days, duration of each session depending of ulceration area - device was set up to develop $4 \mathrm{~J} / \mathrm{cm}^{2}$ on average power $65 \mathrm{~mW}$, various pharmacological agents locally, 4 weeks total

US group: $0.5 \mathrm{~W} / \mathrm{cm}^{2}-$ once a day, duration of each session depending on ulceration area: $5 \mathrm{~cm}^{2}$ received 5 minutes, plus 1 minute more for each $1 \mathrm{~cm}^{2}$ of additional ulcer area, 4 weeks total, $0.9 \%$ $\mathrm{NaCl}$ locally

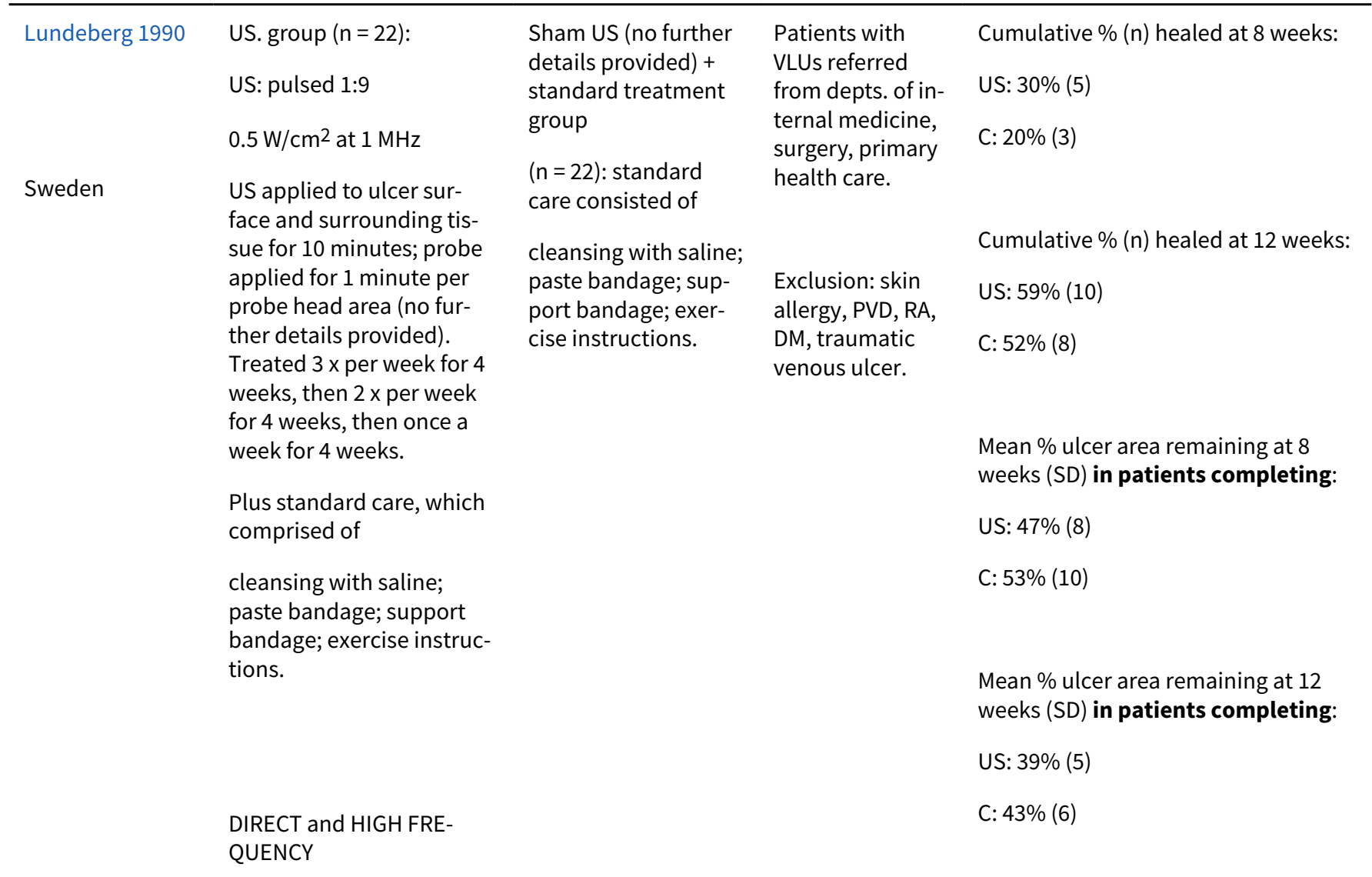

12/44 patients withdrew ( 7 placebo group, 5 US group).

Placebo: 3 allergy, 1 pain, 3 DNA/refused.

US: 2 allergy, 1 pain, 2 DNA/refused 
Table 1. Data extraction table (Continued)

Peschen 1997

Germany

Outpatient clinic
US group $(n=12)$ :

US treatment involved placing legs in footbath of water at $32^{\circ} \mathrm{C}-34^{\circ} \mathrm{C}$ filled to $10 \mathrm{~cm}$ above the ulcer. US sound head transducer immersed in bath and placed in line with ulcer 5 $\mathrm{cm}$ away. The continuous US was given for $10 \mathrm{~min}$ utes at $30 \mathrm{kHz}, 0.1 \mathrm{~W} / \mathrm{cm}^{2} 3$ $x$ per week.

Standard care was also given.

This comprised HCL dressings (Coloplast); compression therapy using "strong-quality elastic compression bandages (Beiersdorf)"

INDIRECT and LOW FREQUENCY
Sham US group ( $\mathrm{n}$ = 12): sham US plus standard care

Sham procedure involved placing legs in footbath of water at $32{ }^{\circ} \mathrm{C}-34^{\circ} \mathrm{C}$ filled to $10 \mathrm{~cm}$ above the ulcer. US sound head transducer immersed in bath and placed in line with ulcer $5 \mathrm{~cm}$ away. Sham US for 10 minutes $3 x$ per week.

Standard care consisted of

HCL dressings (Coloplast); compression therapy using "strong-quality elastic compression bandages (Beiersdorf)"
24 people attending outpatients clinic.

Included: people with chronic VLUs at least $2 \mathrm{~cm}^{2}$ and 3 months' duration. Clinical diagnosis of VLU confirmed by history, Doppler US, light reflection rheography, ABPI of 0.8 or above.

Excluded: arterial disease, liver, cardiac or renal insufficiency, heamorrhagic gastroduodenitis, colitis, leukaemia, diabetes, RA, treatment allergy.
Complete ulcer healing at 12 weeks:

US: $2 / 12$

C: $0 / 12$ (or $0 / 10$ completers)

Mean \% decrease in ulcer area 12 weeks:

\section{US: $55.4 \%$}

C: $16.5 \%$

No variance data

$p<0.007$

Micro-bleeding around the ulcer:

US: 5

C: 0

Pain:

US: $3 / 12$

C: $4 / 10$ pain free

Irritation:

US: $8 / 12$

C: 0

8 US patients felt tingling sensation during US.

After 12 wk treatment phase, standard care continued.

At 3 months post treatment:

Mean ulcer area:

US: $30.6 \%$

C: $70.2 \%$

Mean change ulcer radius ( $\mathrm{mm}$ )

Therapeutic ultrasound for venous leg ulcers (Review) 
Table 1. Data extraction table (Continued)

US: $9.9 \mathrm{~mm}(n=12)$

C: $5.3 \mathrm{~mm}(\mathrm{n}=10)$

$(\mathrm{P}<0.012)$

\section{Taradaj 2007}

Poland
US group $(n=24)$ : sonotherapy with sonicator 730 device, in water bath, $1 \mathrm{MHZ}, 0.5 \mathrm{~W} / \mathrm{cm}^{2}$, duration dependent on area of ulceration - e.g. 5 $\min$ for $\leqq 5 \mathrm{~cm}^{2}$ ), 6 days/ week for 7 weeks plus pharmacotherapy
Taradaj 2008

Poland

No surgery + US group: US, compression and drug therapy

Drug therapy was flavonoid (450 mg diosmin, 50 mg hesperidin), 2 tabs (one of each) twice daily.

Ulcers covered by saline soaks. Dressings changed once day only in clinic.

Ultrasound; $0.5 \mathrm{~W} / \mathrm{cm}^{2}$ pulsed; impulse $2 \mathrm{mS}$, interval $8 \mathrm{mS}$. Frequency 1 $\mathrm{MHz}$. Performed in a bath
All participants used moist normal saline dressing, and pharmacotherapy (diosmin $450 \mathrm{mg}$ and hesperidin $50 \mathrm{mg}$ combined as proprietary preparation (Detralex)

All patients: treatment duration 7 weeks.

Compression group ( $n=25)$ : compression plus stocking and pharmacotherapy

Standard care group cotherapy $(n=24)$ : pharma-

People with venous ulcers who had undergone venous surgery by modified Babcock method.

Surgery - US group $(n=20)$ : surgery plus compression and drug therapy group $(n=20)$ : compression and drug therapy

People with venous disease assessed by symptoms and Duplex scanning. All offered venous surgery. Those refusing surgery were randomised to US or no US.

Group 1 vs. Group 2

Group 3 vs. Group 4

\section{Numbers completely healed at 7} weeks:

Group 1: 6/21

Group 2: 6/20

Group 3: 6/20

Drug therapy was flavonoid (450 mg diosmin, $50 \mathrm{mg}$ hesperidin), 2 tabs (one of each) twice daily.

Ulcers covered by saline soaks. Dressings changed once day only in clinic. 
Table 1. Data extraction table (Continued) of water with temp $34^{\circ} \mathrm{C}$. probe head $10 \mathrm{~cm}^{2}$ placed $2 \mathrm{~cm}$ above ulcer. An ulcer of $5 \mathrm{~cm}^{2}$ or less had 5 minutes treatment, with 1 minute more for each 1 $\mathrm{cm}^{2}$ by which the ulcer exceeded this size. If larger than $20 \mathrm{~cm}^{2}$ the ulcer was divided in 2. Treatment daily for 6 days/week for 7 weeks.

INDIRECT and HIGH FREQUENCY

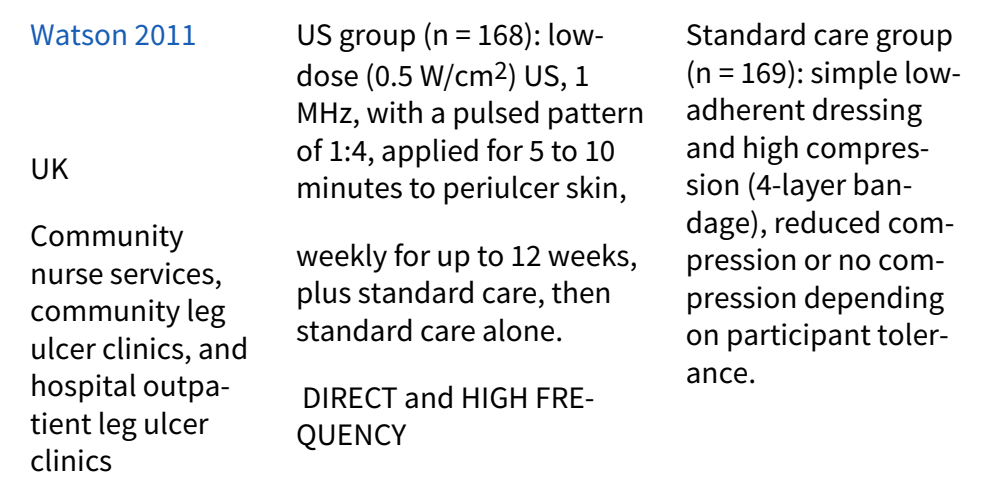

337 patients with hard-to-heal venous leg ulcers i.e., ulcer of 6 months' duration or more and/or area greater than 5 $\mathrm{cm}^{2}$. Considered a venous ulcer if no other obvious causative factor and ulcer appeared clinically venous (moist, shallow, irregular shape, venous eczema, ankle oedema, lipodermatosclerosis, ulcer not confined to the foot). Participants had to have ABPI of 0.8 or greater. Excluded if poorly controlled diabetes, ankle prostheses, thrombophlebitis, active infection including cellulitis, local or metastatic cancer.
Hazard ratio* for US vs. SC 0.99 (0.70 to 1.40$), p=0.969$ (NSD).

* the analysis adjusted for centre as a random effect, ulcer area (from baseline tracing), ulcer duration and whether or not the patient was treated with high-compression bandaging.

Median time (for all ulcers) to complete healing:

US: 365 days ( $95 \% \mathrm{Cl} 224$, inestimable)

SC: 328 days $(95 \% \mathrm{Cl} 235$, inestimable) $\mathrm{P}=0.9051, \log$ rank.

Ulcers completely healed/not healed (\%) at 8 wks (personal communication):

US: $9 / 168$

SC: $15 / 169$

Ulcers completely healed/not healed (\%) at 12 wks (personal communication):

US: $26 / 168$

\section{SC: $25 / 169$}

Ulcers completely healed/not healed (\%) at 12 month (personal communication):

US: $72 / 168$ 
Table 1. Data extraction table (Continued)

SC: $78 / 169$

HRQoL by SF-12:

Mean Baseline PCS (SD):

US: $36.55(11.32) ; \mathrm{n}=160$

SC: $35.33(11.47) ; n=167$

3 month PCS (SD):

US:33.87 (11.49); $\mathrm{n}=143$

SC: 34.96 (11.39); $n=142$

12 month PCS (SD):

US:34.61 (12.09); $\mathrm{n}=118$

SC: 35.57 (11.39); $\mathrm{n}=111$

Baseline MCS (SD):

US: 46.72 (11.52); $\mathrm{n}=160$

SC: $47.11(11.29) ; n=167$

3 month MCS (SD):

US: $45.95(12.22) ; n=143$

SC: $46.83(11.38) ; n=142$

12 month MCS (SD):

US: $47.51(11.54) ; n=118$

SC: 45.41 (12.15); $n=111$

Serious

Adverse Events (SAEs):

US: 35/168 patients

SC: $29 / 169$ patients

Non serious AEs:

US: $86 / 168$ patients

SC: $67 / 169$ patients

NS using random effects negative binomial regression $(p=0.3904)$. 
Table 1. Data extraction table (Continued)

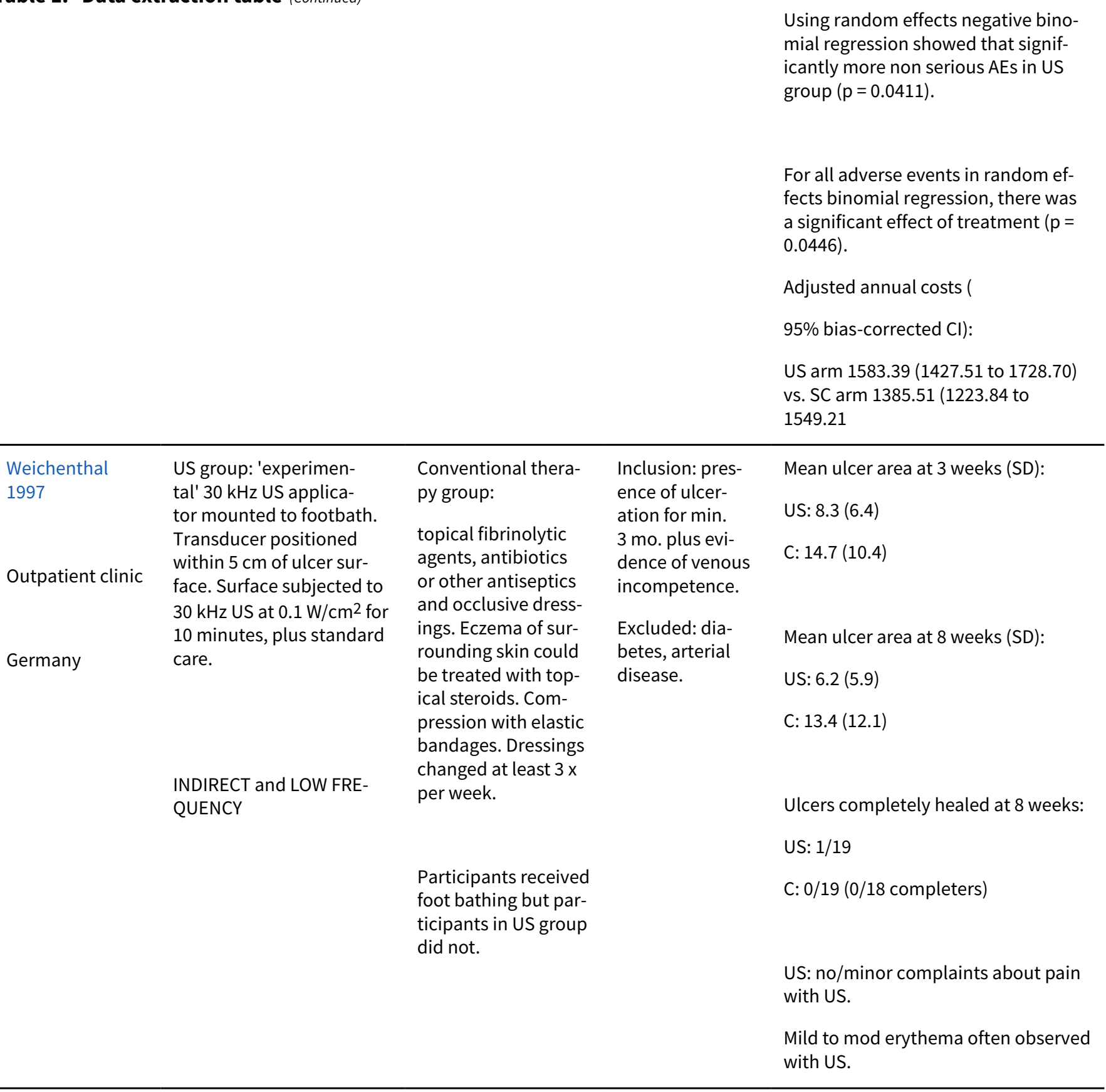

\section{AP PEN DICES}

\section{Appendix 1. CENTRAL search strategy for this update (2016)}

\#1 MeSH descriptor Varicose Ulcer explode all trees

\#2 MeSH descriptor Leg Ulcer explode all trees

\#3 (varicose NEXT ulcer ${ }^{\star}$ ) or (venous NEXT ulcer ${ }^{\star}$ ) or (leg NEXT ulcer ${ }^{\star}$ ) or (foot NEXT ulcer ${ }^{\star}$ ) or (stasis NEXT ulcer ${ }^{\star}$ )

\#4 (\#1 OR \#2 OR \#3)

\#5 MeSH descriptor Ultrasonic Therapy explode all trees

\#6 ultrasound NEAR/5 therap*

\#7 ultrason* NEAR/5 therap* 
\#8 (\#5 OR \#6 OR \#7)

\#9 (\#4 AND \#8)

\section{Appendix 2. Search strategy for 2011 update}

For the original review, the Cochrane Wounds Specialised Register was searched for RCTs of therapeutic ultrasound up to December 1999. The reference lists of reviews and papers obtained from this search were scrutinised to identify additional studies.

For the 2011 update, review authors performed a search of the Cochrane Wounds Specialised Register (searched 01/07/11). Trials on the register are identified by hand searching of relevant journals, conference proceedings, and searching electronic databases. We carried out an additional search of the following electronic databases:

The Cochrane Central Register of Controlled Trials (CENTRAL) - The Cochrane Library Issue 2, 2011

Ovid MEDLINE - 1950 to June Week 42011

Ovid EMBASE - 1980 to 2011 Week 25

EBSCO CINAHL - 1982 to 24 June 2011

Review authors searched The Cochrane Central Register of Controlled Trials (CENTRAL) using the following strategy, which was adapted for other databases where appropriate:

\#1 MeSH descriptor Varicose Ulcer explode all trees

\#2 MeSH descriptor Leg Ulcer explode all trees

\#3 (varicose NEXT ulcer ${ }^{\star}$ ) or (venous NEXT ulcer ${ }^{\star}$ ) or (leg NEXT ulcer ${ }^{\star}$ ) or (foot NEXT ulcer ${ }^{\star}$ ) or (stasis NEXT ulcer ${ }^{\star}$ )

\#4 (\#1 OR \#2 OR \#3)

\#5 MeSH descriptor Ultrasonic Therapy explode all trees

\#6 ultrasound NEAR/5 therap*

\#7 ultrason* NEAR/5 therap*

\#8 (\#5 OR \#6 OR \#7)

\#9 (\#4 AND \#8)

The MEDLINE search was combined with the Cochrane highly sensitive search strategy for identifying reports of randomised controlled trials (Higgins 2005). The EMBASE and CINAHL searches were combined with the trial filters developed by the Scottish Intercollegiate Guidelines Network (SIGN).

We contacted researchers to obtain any unpublished data when needed. Reference lists of potentially useful articles were also searched. There was no restriction by language, date or publication status.

\section{Appendix 3. Ovid MEDLINE search strategy}

1 exp Leg Ulcer/

2 (varicose ulcer ${ }^{\star}$ or venous ulcer ${ }^{\star}$ or leg ulcer ${ }^{\star}$ or foot ulcer* or (feet adj ulcer ${ }^{\star}$ ) or stasis ulcer* or (lower extremit* adj ulcer ${ }^{\star}$ ) or crural ulcer* or ulcus cruris).tw.

3 or $1-2$

4 exp Ultrasonic Therapy/

5 (ultrasound adj5 therap*).tw.

6 (ultrason ${ }^{\star}$ adj 5 therap*).tw.

7 or/4-6

83 and 7

9 randomized controlled trial.pt.

10 controlled clinical trial.pt.

11 randomi?ed.ab.

12 placebo.ab.

13 clinical trials as topic.sh.

14 randomly.ab.

15 trial.ti.

16 or/9-15

17 exp animals/ not humans.sh.

1816 not 17

198 and 18

\section{Appendix 4. Ovid Embase search strategy}

1 exp Leg Ulcer/

2 (varicose ulcer ${ }^{\star}$ or venous ulcer ${ }^{\star}$ or leg ulcer ${ }^{\star}$ or foot ulcer ${ }^{\star}$ or (feet adj ulcer ${ }^{\star}$ ) or stasis ulcer ${ }^{\star}$ or (lower extremit ${ }^{\star}$ adj ulcer ${ }^{\star}$ ) or crural ulcer* or ulcus cruris).tw. 
3 or $/ 1-2$

4 exp Ultrasonic Therapy/

5 (ultrasound adj5 therap*).tw.

6 (ultrason\$ adj5 therap*).tw.

7 or/4-6

83 and 7

9 Randomized controlled trials/

10 Single-Blind Method/

11 Double-Blind Method/

12 Crossover Procedure/

13 (random $^{\star}$ or factorial ${ }^{\star}$ or crossover ${ }^{\star}$ or cross over ${ }^{\star}$ or cross-over $^{\star}$ or placebo ${ }^{\star}$ or assign ${ }^{\star}$ or allocat ${ }^{\star}$ or volunteer $\left.{ }^{\star}\right)$.ti,ab.

14 (doubl $^{\star}$ adj blind $\left.{ }^{\star}\right) \cdot$ ti,ab.

15 (singl ${ }^{\star}$ adj blind $\left.{ }^{\star}\right)$.ti,ab.

16 or/9-15

17 exp animals/ or exp invertebrate/ or animal experiment/ or animal model/ or animal tissue/ or animal cell/ or nonhuman/

18 human/ or human cell/

19 and/17-18

2017 not 19

2116 not 20

228 and 21

\section{Appendix 5. EBSCO CINAHL Plus search strategy}

\section{S28 S10 AND S27}

S27 S15 OR S16 OR S17 OR S18 OR S19 OR S20 OR S21 OR S22 OR S23 OR S24 OR S25 OR S26

$\mathrm{S} 26 \mathrm{TI}$ allocat* random $^{\star}$ or AB allocat ${ }^{\star}$ random*

S25 MH "Quantitative Studies"

S24 TI placebo* or AB placebo*

$\mathrm{S} 23 \mathrm{MH}$ "Placebos"

S22 TI random* allocat* or AB random* allocat*

S21 MH "Random Assignment"

$\mathrm{S} 20 \mathrm{TI}$ randomi?ed control ${ }^{\star}$ trial $^{\star}$ or $\mathrm{AB}$ randomi?ed control ${ }^{\star}$ trial $^{*}$

S19 AB ( singl* or doubl* or trebl* or tripl* $)$ and AB ( blind ${ }^{\star}$ or mask ${ }^{\star}$ )

$\mathrm{S} 18 \mathrm{TI}$ ( singl ${ }^{\star}$ or doubl ${ }^{\star}$ or trebl ${ }^{\star}$ or tripl ${ }^{\star}$ ) and $\mathrm{TI}$ ( blind $^{\star}$ or mask ${ }^{\star}$ )

S17 TI clinic ${ }^{\star} \mathrm{N} 1$ trial $^{\star}$ or AB clinic* N1 trial*

S16 PT Clinical trial

S15 MH "Clinical Trials+"

S10 S4 and S9

$\mathrm{S} 9 \mathrm{~S} 5$ or $\mathrm{S} 6$ or $\mathrm{S} 7$ or $\mathrm{S} 8$

S8 TI ultrason* N5 therap* or AB ultrason* N5 therap*

S7 TI ultrasound N5 therap* or AB ultrasound N5 therap*

S6 (MH "Ultrasonics")

S5 (MH "Ultrasonic Therapy")

S4 S1 or S2 or S3

S3 TI lower extremity N3 ulcer ${ }^{\star}$ or AB lower extremity N3 ulcer*

S2 TI (varicose ulcer ${ }^{\star}$ or venous ulcer ${ }^{\star}$ or leg ulcer ${ }^{\star}$ or foot ulcer ${ }^{\star}$ or (feet N1 ulcer ${ }^{\star}$ ) or stasis ulcer ${ }^{\star}$ or crural ulcer $^{\star}$ ) or AB (varicose ulcer ${ }^{\star}$ or venous ulcer ${ }^{\star}$ or leg ulcer ${ }^{\star}$ or foot ulcer ${ }^{\star}$ or (feet N1 ulcer $^{\star}$ ) or stasis ulcer ${ }^{\star}$ or crural ulcer $^{\star}$ )

S1 (MH "Leg Ulcer+")

\section{Appendix 6. Cochrane tool for assessing risk of bias}

\section{Was the allocation sequence randomly generated?}

\section{Low risk of bias}

The investigators describe a random component in the sequence generation process, such as referring to a random number table; using a computer random number generator; tossing a coin; shuffling cards or envelopes; throwing dice; drawing of lots.

\section{High risk of bias}

The investigators describe a non-random component in the sequence generation process. Usually, the description would involve some systematic, non-random approach, for example sequence generated by odd or even date of birth; sequence generated by some rule based on date (or day) of admission; sequence generated by some rule based on hospital or clinic record number. 


\section{Unclear risk of bias}

Insufficient information about the sequence generation process provided to permit judgement of low or high risk of bias.

\section{Was the treatment allocation adequately concealed?}

\section{Low risk of bias}

Participants and investigators enrolling participants could not foresee assignment because one of the following, or an equivalent method, was used to conceal allocation: central allocation (including telephone, web-based and pharmacy-controlled randomisation); sequentially numbered drug containers of identical appearance; sequentially numbered, opaque, sealed envelopes.

\section{High risk of bias}

Participants or investigators enrolling participants could possibly foresee assignments and thus introduce selection bias, such as allocation based on using an open random allocation schedule (e.g. a list of random numbers); assignment envelopes without appropriate safeguards (e.g. envelopes were unsealed, non-opaque or not sequentially numbered); alternation or rotation; date of birth; case record number; any other explicitly unconcealed procedure.

\section{Unclear risk of bias}

Insufficient information provided to permit judgement of low or high risk of bias. This is usually the case if the method of concealment is not described or is not described in sufficient detail to allow a definitive judgement, for example if the use of assignment envelopes is described, but it remains unclear whether envelopes were sequentially numbered, opaque and sealed.

\section{Blinding (participants, personnel and outcome assessors) - was knowledge of the allocated interventions adequately prevented during the study?}

\section{Low risk of bias}

Any one of the following:

- No blinding, but the review authors judge that the outcome and the outcome measurement are not likely to be influenced by lack of blinding.

- Blinding of participants and key study personnel ensured, and unlikely that the blinding could have been broken.

- Either participants or some key study personnel were not blinded, but outcome assessment was blinded and the non-blinding of others is unlikely to introduce bias.

\section{High risk of bias}

Any one of the following:

- No blinding or incomplete blinding, and the outcome or outcome measurement is likely to be influenced by lack of blinding.

- Blinding of key study participants and personnel attempted, but likely that the blinding could have been broken.

- Either participants or some key study personnel were not blinded, and the non-blinding of others is likely to introduce bias.

\section{Unclear risk of bias}

Either of the following:

- Insufficient information provided to permit judgement of low or high risk of bias.

- The study did not address this outcome.

\section{Were incomplete outcome data adequately addressed?}

\section{Low risk of bias}

Any one of the following:

- No missing outcome data.

- Reasons for missing outcome data unlikely to be related to true outcome (for survival data, censoring unlikely to be introducing bias).

- Missing outcome data balanced in numbers across intervention groups, with similar reasons for missing data across groups.

- For dichotomous outcome data, the proportion of missing outcomes compared with observed event risk is not enough to have a clinically relevant impact on the intervention effect estimate.

- For continuous outcome data, plausible effect size (difference in means or standardised difference in means) among missing outcomes is not enough to have a clinically relevant impact on observed effect size.

- Missing data have been imputed using appropriate methods. 


\section{High risk of bias}

Any one of the following:

- Reason for missing outcome data likely to be related to true outcome, with imbalance in numbers or reasons for missing data across intervention groups.

- For dichotomous outcome data, the proportion of missing outcomes compared with observed event risk is enough to induce clinically relevant bias in intervention effect estimate.

- For continuous outcome data, plausible effect size (difference in means or standardised difference in means) among missing outcomes is enough to induce clinically relevant bias in observed effect size.

- 'As-treated' analysis done with substantial departure of the intervention received from that assigned at randomisation.

- Potentially inappropriate application of simple imputation.

\section{Unclear risk of bias}

Either of the following:

- Insufficient reporting of attrition/exclusions to permit judgement of low or high risk of bias (e.g. number randomised not stated, no reasons for missing data provided).

- The study did not address this outcome.

\section{Are reports of the study free of the suggestion of selective outcome reporting?}

\section{Low risk of bias}

Either of the following:

- The study protocol is available and all of the study's prespecified (primary and secondary) outcomes that are of interest in the review have been reported in the prespecified way.

- The study protocol is not available but it is clear that the published reports include all expected outcomes, including those that were prespecified (convincing text of this nature may be uncommon).

\section{High risk of bias}

Any one of the following:

- Not all of the study's prespecified primary outcomes have been reported.

- One or more primary outcomes are reported using measurements, analysis methods or subsets of the data (e.g. subscales) that were not prespecified.

- One or more reported primary outcomes were not prespecified (unless clear justification for their reporting is provided, such as an unexpected adverse effect).

- One or more outcomes of interest in the review are reported incompletely so that they cannot be entered in a meta-analysis.

- The study report fails to include results for a key outcome that would be expected to have been reported for such a study.

\section{Unclear risk of bias}

Insufficient information provided to permit judgement of low or high risk of bias. It is likely that the majority of studies will fall into this category.

\section{Other sources of potential bias}

\section{Low risk of bias}

The study appears to be free of other sources of bias.

\section{High risk of bias}

There is at least one important risk of bias. For example, the study:

- had a potential source of bias related to the specific study design used; or

- has been claimed to have been fraudulent; or

- had some other problem.

\section{Unclear risk of bias}

There may be a risk of bias, but there is either: 
- insufficient information to assess whether an important risk of bias exists; or

- insufficient rationale or evidence that an identified problem will introduce bias.

WHAT'S NEW

\begin{tabular}{lll}
\hline Date & Event & Description \\
\hline 12 May 2017 & New search has been performed & Third update. New search with three new studies added (Franek \\
& 2006; Taradaj 2007; Watson 2011). The data analyses and 'Sum- \\
& mary of findings' table have been redone. The conclusions are \\
& strengthened by addition of a new large trial (Watson 2011). One \\
& trial is currently awaiting assessment. A new co-author (Zhenmi \\
& Liu) has joined Nicky Cullum, replacing authors of the previous \\
& update Deyaa Al-Kurdi and Sally Bell-Syer.
\end{tabular}

12 May $2017 \quad$ New citation required but conclusions Updated. Conclusions strengthened.

have not changed

\section{H I S T O R Y}

Protocol first published: Issue 4, 1998

Review first published: Issue 4, 2000

\begin{tabular}{lll}
\hline Date & Event & Description \\
\hline 7 May 2010 & New search has been performed & $\begin{array}{l}\text { New searches have been conducted and two new studies added } \\
\text { to the review (Dolibog 2008; Taradaj 2008). Two previously in- } \\
\text { cluded trials have now been excluded as they were quasi-ran- } \\
\text { domised (Dyson 1976; Roche 1984). }\end{array}$ \\
\hline 7 May 2010 & $\begin{array}{l}\text { New citation required and conclusions } \\
\text { have changed }\end{array}$ & $\begin{array}{l}\text { Second update. The review has been substantially re-written and } \\
\text { re-structured. We have re-structured the review to distinguish } \\
\text { high and low frequency ultrasound. We have also added a Sum- } \\
\text { mary of Findings table. }\end{array}$ \\
\hline
\end{tabular}

\begin{tabular}{lll}
\hline 30 April 2008 & Amended & Converted to new review format. \\
\hline 2 November 2007 & $\begin{array}{l}\text { New citation required and conclusions } \\
\text { have changed }\end{array}$ & $\begin{array}{l}\text { Substantive amendment. } \\
\text { For this first update, new searches were carried out in August }\end{array}$ \\
& 2007 and one new trial met the inclusion criteria for the review \\
& (Franek 2004). Additional citations were identified for existing tri- \\
& als and these were added to the appropriate reference lists. One \\
& trial (Franek 2006a) is currently awaiting assessment, it has been \\
& translated but clarification has been sought from the author as \\
& to whether this trial is a further publication of Franek 2004.
\end{tabular}

\section{CONTRIBUTIONS OF AUTHORS}

Nicky Cullum: conceived the original review; designed, coordinated and advised on this update; extracted data; checked the quality of data extraction; analysed or interpreted data; performed statistical analysis; checked the quality of the statistical analysis; produced the first draft; contributed to writing and editing the update; made an intellectual contribution; approved the final review update prior to submission; wrote to study author / experts / companies; and is a guarantor of the review update.

Zhenmi Liu: redrafted the review for this latest update; extracted data; checked the quality of data extraction; analysed or interpreted data; undertook and checked quality assessment; performed statistical analysis; checked the quality of the statistical analysis; contributed

Therapeutic ultrasound for venous leg ulcers (Review) 
to writing and editing the review update; made an intellectual contribution to the review update; and approved the final review update prior to submission.

\section{Contributions of the editorial base}

Jo Dumville (Editor): edited the review, advised on methodology, interpretation and review content; approved the final review and review update prior to submission.

Gill Rizzello (Managing Editor): coordinated the editorial process; advised on content; edited the review update.

Reetu Child (Information Specialist): designed the search strategy, ran the searches and edited the search methods section for the update.

Ursula Gonthier (Editorial Assistant): edited the Plain Language Summary and references sections of the review update.

\section{DECLARATIONSOF INTEREST}

Nicky Cullum was a co investigator of one of the studies that is included in this review (Watson 2011). The data extraction and risk of bias assessment for this study was conducted by another reviewer and checked by an independent member of the editorial staff. Nicky Cullum was not involved in signing this review off for publication. Nicky Cullum receives research funding for wounds-related research and systematic reviews from the NIHR.

Zhenmi Liu's employment at the University of Manchester is funded by NIHR (NIHR Research Methods Programme Systematic Review Fellowship NIHR-RMFI-2015-06-52).

\section{SOURCES OF SUPPORT}

\section{Internal sources}

- Division of Nursing, Midwifery and Social Work, School of Health Sciences, Faculty of Biology, Medicine and Health, University of Manchester, UK.

\section{External sources}

- National Institute for Health Research, UK.

This project was supported by the National Institute for Health Research, via Cochrane Infrastructure funding to Cochrane Wounds, and an NIHR Research Methods Programme Systematic Review Fellowship (NIHR-RMFI-2015-06-52- Zhenmi Liu). The views and opinions expressed therein are those of the authors and do not necessarily reflect those of the Systematic Reviews Programme, NIHR, NHS or the Department of Health.

- National Institute for Health Research Collaboration for Leadership in Applied Health Research and Care (NIHR CLAHRC) Greater Manchester Centre, UK.

Nicky Cullum was partly funded by the National Institute for Health Research Collaboration for Leadership in Applied Health Research and Care (NIHR CLAHRC) Greater Manchester. The funder had no role in the design of the studies, data collection and analysis, decision to publish, or preparation of the manuscript. However, the review may be considered to be affiliated to the work of the NIHR CLAHRC Greater Manchester. The views expressed herein are those of the authors and not necessarily those of the NHS, NIHR or the Department of Health.

\section{DIFFERENCES BETWEEN PROTOCOL AND REVIEW}

The decision to undertake a sensitivity analysis comparing alternative ways of dealing with participants who were lost to follow-up was not planned in the protocol, nor was the decision to group ultrasound trials by the ultrasound frequency. We do not envisage, however, that these decisions have introduced bias to the review.

\section{INDEX TERMS}

\section{Medical Subject Headings (MeSH)}

*Ultrasonic Therapy [adverse effects] [economics] [methods]; *Wound Healing; Quality of Life; Randomized Controlled Trials as Topic; Time Factors; Treatment Outcome; Varicose Ulcer [*therapy]

\section{MeSH check words}

Aged; Female; Humans; Male; Middle Aged 